Дмитриева Л. Н., Краснов Я. М., Чумачкова Е.А., Осина Н. А., Сафронов В.А.,

Иванова А.В., Карнаухов И. Г., Караваева Т.Б., Щербакова С. А., Кутырев В. В.

\title{
РАСПРОСТРАНЕНИЕ ВАРИАНТОВ ВИРУСА SARS-COV-2, ВЫЗЫВАЮЩИХ \\ ОЗАБОЧЕННОСТЬ (VOC) И ИНТЕРЕС (VOI) НА ОСНОВЕ КОЛИЧЕСТВА ИХ \\ ГЕНОМОВ, ДЕПОНИРОВАННЫХ В БАЗУ ДАННЫХ GISAID ЗА НЕДЕЛЮ
}

19.06.2021 г. по 25.06.2021 г.

ФКУЗ Российский научно-исследовательский противочумный институт «Микроб» Роспотребнадзора, Саратов, Российская Федераџия

В обзоре представлен анализ геновариантов вируса SARS-CoV-2, вызывающих озабоченность (VOC) и интерес (VOI) на основе их геномов в базе GISAID за неделю с 19.06.2021 г. по 25.06.2021 г.

На сегодняшний день в базе данных GISAID всего представлено 2088 988 геномов вируса SARS-COV-2, за прошедшую неделю в базу данных депонировано еще 73589 геномов.

\section{Варианты вызывающие озабоченность (VOC)}

Информация по обновленным данным о депонированных геномах вируса SARS-COV-2 вариантов VOC: 202012/01, B.1.1.7 (Alpha), 501 Y.V2, B.1.351 (Beta), P.1 (Gamma) и B.1.617.2 (Delta) в базе GISAID дана в Приложении 1 таблица 1.

\section{Вариант VOC 202012/01 (линия B.1.1.7), Alpha}

Относительно 18 июня в базе данных GISAID представлено еще 37629 новых генома вируса SARS-COV-2, относящихся к варианту VOC 202012/01 (Alpha). Итого 920205 геномов варианта 202012/01.

В базе данных GISAID зафиксировано 145 стран и территорий, в которых циркулирует геномы варианта Alpha: Азербайджан, Албания, Ангилья, Ангола, Австралия, Австрия, Аргентина, Армения, Аруба, Бангладеш, Бахрейн, Барбадос, Белиз, Бельгия, Беларусь, Бермуды, Бразилия, Буркина- Фасо, Болгария, Бонэйр, Великобритания, Венгрия, Вьетнам, Габон, Гаити, Гана, Гамбия, Гватемала, Гваделупа, Гвине́я-Биса́у, Германия, Гибралтар, Гренада, Греция, Грузия, Гуам, Дания, Джибути, ДРК, Доминика, Египет, Израиль, Индия, Индонезия, Иордания, Ирак, Иран, Исландия, Испания, Италия, Ирландия,Казахстан, Канада, Камбоджа, Камерун, Каймановые острова, Катар, Кения, Кипр, Китай, Колумбия, Косово, Кот-д’Ивуар, Кюрасао, Коста-Рика, Кувейт, Латвия, Ливан, Литва, Лихтенштейн, Люксембург, Майотта, Мальта, Малайзия, Малави, Мартиника, Мексика, Молдавия, Маври́кий, Марокко, 
Монако, Монтсерра́т, Мьянма, Нигерия, Нидерланды, Новая Зеландия, Норвегия, Непал, ОАЭ, Оман, Палестина, Пакистан, Перу, Польша, Португалия, Парагвай, Республика Гвинея, Респу́блика Конго, Реюньон, Россия, Румыния, Руанда, Сев. Македония, Саудовская Аравия, Сенегал, Сент-Люсия, Сербия, Сингапур, Синт-Мартен, Сомали, Словакия, Словения, Суринам, США, Таиланд, Тайвань, Того, Тринидад и Тобаго, Тунис, Турция, Украина, Уганда, Уоллис и Футуна, Филиппины, Финляндия, Фарерские острова, Франция, Французская Гвиана, Хорватия, Черногория, Чехия, Чили, Центральноафриканская Республика, Швеция, Швейцария, Шри-Ланка, Эстония, Эквадор, Экваториальная Гвинея, Эфиопия, ЮАР, Южная Корея, Ямайка, Япония.

За последние 4 недели в абсолютных значениях наибольшее число геномов варианта 202012/01 (Alpha) депонировали Дания (7096), Германия (5180), Великобритания (4808), США (3659). На 25 июня 2021 года динамика доли депонированных в базу GISAID геномов вируса вариантов 202012/01 (Alpha) дает следующую картину по странам:

Австралия - уменьшение от 9,5 до 8,1\%;

Австрия - уменьшение от 64,2 до $22,9 \%$;

Аруба - уменьшение от 38,1 до 3,7 \%;

Бангладеш - увеличение от 0 до 3,7 \%;

Бельгия - стабилизация на уровне $66,8 \%$;

Бразилия - стабилизация на уровне $1,2 \%$;

Великобритания - уменьшение от 15,2 до $10,0 \%$;

Гваделупа - уменьшение от 80,0 до $11,1 \%$;

Греция - увеличение от 31,1 до 42,7\%;

Дания - уменьшение от 98,7 до 96,8 \%;

Индонезия - уменьшение от 5,7 до 2,8\%;

Ирландия - уменьшение от 52,3 до 40,2 \%;

Италия - увеличение от 44,6 до 50,0 \%;

Испания - уменьшение от 62,3 до 51,1\%;

Израиль - увеличение от 0 до 41,2 \%;

Камбоджа - уменьшение от 87,9 до 68,5 \%;

Китай - уменьшение от 100 до 29,0\%;

Коста-Рика - уменьшение от 36,4 до $0 \%$;

Кувейт - стабилизация на уровне $62,5 \%$;

Литва - уменьшение от 49,4 до 46,0\%;

Люксембург - уменьшение от 43,9 до 0\%;

Мальта - уменьшение от 69,2 до 0\%;

Мартиника - уменьшение от 100,0 до 0\%;

Мексика - уменьшение от 19,6 до 18,9\%;

Нидерланды - уменьшение от 69,7 до 66,8 \%;

Норвегия - стабилизация на уровне $71,4 \%$;

Польша - уменьшение от 57,8 до 43,0 \%;

Португалия - увеличение с 11,6 до 44,0 \%;

Румыния - увеличение от 0 до 18,8 \%;

Россия - уменьшение от 6,7 до $1,5 \%$; 
Сингапур - стабилизация на уровне $0,6 \%$;

Синт-Мартен - увеличение от 48,7 до 83,3\%

Словакия - уменьшение от 61,3 до 8,9\%;

Словения - увеличение от 45,5 до 65,8 \%;

США - уменьшение от 46,3 до 39,9\%;

Тайвань - уменьшение от 37,8 до 40,0\%;

Таиланд - уменьшение от 37,5 до $12,8 \%$;

Турция - уменьшение от 1,2 до $0 \%$;

Франция - уменьшение от 78,6 до 33,6 \%;

Чили - уменьшение от 3,5 до $0 \%$;

Швеция - увеличение от 37,7 до $72,2 \%$;

Швейцария - уменьшение от 71,5 до 66,1 \%;

Эквадор - уменьшение от 10,1 до 6,7 \%;

Япония - увеличение от 24,3 до 53,5 \%.

На анализируемой неделе в большинстве стран мира наблюдается снижение доли выделенных вариантов вируса из Великобритании, геномы которых депонированы в базе GISAID.

\section{Вариант 501Y.V2, ген S (линия B.1.351), Beta.}

За прошедшую неделю в базу данных было добавлено еще 1416 геномов, относящихся к линии В.1.351. С 01 октября 2020 года представлено всего 25644 генома вируса линии В.1.351.

Всего по базе данных GISAID депонированы геномы варианта Beta из 95 стран и территорий: Австралия, Австрия, Аруба, Ангола, Аргентина, Бангладеш, Бахрейн, Ботсвана, Бельгия, Бразилия, Бруней, Великобритания, Гана, Гваделупа, Гвине́я-Биса́у, Германия, Габон, Греция, Гуама, Дания, ДР Конго, Замбия, Зимбабве, Израиль, Индонезия, Иордания, Италия, Испания, Ирландия, Иран, Индия, Индонезия, Камбоджа, Канада, Коста-Рика, Камерун, Котд’Ивуар, Кения, Коморские острова, Китай, Латвия, Лесото, Люксембург, Мадагаскар, Малави, Малайзия, Мальта, Мартини́ка, Монако, Мозамбик, Майотта, Маврикий, Мексика, Намибия, Нидерланды, Норвегия, Новая Зеландия, ОАЭ, Пакистан, Панама, Португалия, Польша, Россия, Руанда, Румыния, Реюньон, Саудовская Аравия, Северная Македония, Сингапур, СинтМартен, Суринам, Словакия, Словения, США, Тайвань, Тайланд, Тунис, Турция, Того, Филиппины, Финляндия, Франция, Французская Гвиана, Хорватия, Чили, Чехия, Швеция, Швейцария, Шри-Ланка, Экваториальная Гвинея, Эсватини, Эстония, Южная Корея, ЮАР, Япония.

За последние 4 недели в абсолютных значениях наибольшее число геномов варианта 501Y.V2 (линия В.1.351) депонировали Франция (93) и Ботсвана (50). Информация по числу депонированных геномов варианта 501Y.V2 обновилась из следующих стран:

Австралия - стабилизация на уровне 4,7 \%; 
Австрия - стабилизация на уровне $1,3 \%$;

Бельгия - стабилизация на уровне $0,5 \%$;

Ботсвана - увеличение от 85,7 до 89,3\%;

Дания - уменьшение от 0,2 до 0\%;

Великобритания - стабилизация на уровне $0,05 \%$;

Германия - стабилизация на уровне $0,4 \%$;

Израиль - увеличение от 0 до $1,5 \%$;

Кения - увеличение от 0 до 9,1\%;

Малайзия - увеличение от 0 до 37,5\%;

Нидерланды - стабилизация на уровне $0,2 \%$;

Новая Зеландия - уменьшение от 25,0 до $0 \%$;

Норвегия - стабилизация на уровне $0,2 \%$;

Пакистан - уменьшение от 20,0 до 0\%;

Реюньон - уменьшение от 47,4 до 14,7\%;

Сингапур - стабилизация на уровне $2,2 \%$;

США - уменьшение от 0,4 до $0,2 \%$;

Турция - уменьшение от 0,4 до $0 \%$;

Чехия - стабилизация на уровне $1,3 \%$;

Франция - уменьшение от 3,6 до 2,8 \%;

Швеция - увеличение от 0,4 до $0,8 \%$;

Швейцария - стабилизация на уровне $0,6 \%$;

ЮАР - уменьшение от 88,9 до 47,6 \%;

Япония - увеличение от 4,1 до 6,1\%.

Согласно представленным данным, в странах мира наблюдается как увеличение, так и уменьшение процентной доли вариантов депонированных геномов, относящихся к линии 501Y.V2.

\section{Вариант P.1 (линия B.1.1.28), Gamma.}

C 1 ноября 2020 года в базе GISAID представлено 41189 геномов вируса SARS-CoV-2 варианта P.1 Gamma. За последнюю неделю в базу данных было депонировано еще 4660 геномов данного варианта вируса

В базе данных GISAID на 25 июня циркуляция геноварианта Gamma зафиксирована в 58 странах и территориях: Аргентина, Аруба, Австралия, Австрия, Бангладеш, Барбадос, Бразилия, Бельгия, Боливия, Великобритания, Венесуэла, Гаити, Германия, Гвиана, Дания, Доминиканская Республика, Израиль, Италия, Ирландия, Испания, Иордания, Канада, Колумбия, КостаРика, Китай, Кюрасао, Литва, Люксембург, Мальта, Мексика, Нидерланды, Норвегия, Новая Зеландия, Парагвай, Перу, Португалия, Польша, Румыния, Словения, Сингапур, Суринам, США, Тайвань, Тринидад и Тобаго, Турция, Уругвай, Фарерские острова, Филиппины, Финляндия, Франция, Французская Гвиана, Чили, Чехия, Швейцария, Швеция, Эквадор, Южная Корея, Япония.

За последние 4 недели в абсолютных значениях наибольшее число геномов варианта Gamma депонировали США (874), Бразилия (204), Бельгия 
(172), Мексика (133). Информация по числу депонированных геномов варианта Gamma обновилась из следующих стран:
Аруба - увеличение от 23,8 до $29,8 \%$;
Австрия - уменьшение с 2,4 до 0,9\%;
Бельгия - стабилизация на уровне $7,6 \%$;
Бразилия - уменьшение от 44,7 до 40,9\%;
Великобритания - стабилизация на уровне $0,04 \%$;
Дания - уменьшение от 0,2 до $0 \%$;
Доминиканская Республика - увеличение от 0 до 33,3\%;
Гаити - уменьшение от 48,2 до $0 \%$;
Германия - увеличение от 0,2 до $08 \%$;
Италия - увеличение от 1,0 до 4,3\%;
Испания - стабилизация на уровне 3,0 \%;
Канада - уменьшение от 9,9 до $0 \%$;
Коста-Рика - уменьшение от 18,2 до $0 \%$;
Литва - увеличение от 0 до $0,2 \%$;
Мексика - увеличение от 10,6 до 25,5\%;
Нидерланды - увеличение от 1,5 до 2,2 \%;
Норвегия - увеличение от 0 до $0,4 \%$;
Португалия стабилизация на уровне $2,9 \%$;
США - увеличение от 7,9 до 9,5\%;
Франция - уменьшение от 0,8 до 0,3\%;
Французская Гвиана - увеличение от 52,9 до 91,1 \%;
Швеция - увеличение от 0 до $0,3 \%$;
Швейцария - стабилизировалась на уровне 1,0\%;
Чили - уменьшение от 39,7 до 2,3 \%;
Эквадор - увеличение от 5,4 до 10,1\%.

Согласно представленным данным в большинстве стран наблюдается как увеличение, так и снижение доли вариантов Gamma, депонированных в базу данных GISAID.

\section{Вариант Delta (B.1.617.2)}

С декабря 2020 года в базе данных GISAID представлено 78109 геномов вируса SARS-CoV-2 варианта Delta. За последнюю неделю в базу данных было депонировано еще 16395 геномов данного варианта вируса.

На сегодняшний день в базе данных GISAID зафиксировано депонирование варианта Delta из 75 стран и территорий: Австралия, Австрия, Ангилья, Ангола, Аргентина, Аруба, Бангладеш, Барбадос, Бахрейн, Бельгия, Болгария, Ботсвана, Бразилия, Великобритания, Вьетнам, Гана, Гваделупа, Германия, Греция, Грузия, Гуам, Дания, ДРК, Израиль, Индия, Индонезия, Иордания, Иран, Ирландия, Испания, Италия, Камбоджа, Канада, Катар, Китай, Кения, Кувейт, Литва, Люксембург, Маврикий, Малайзия, Малави, Мальта, Марокко, Мексика, Мьянма, Непал, Нидерланды, Новая Зеландия, 
Норвегия, Пакистан, Перу, Польша, Португалия, Реюньон, Россия, Румыния, Сенегал, Сингапур, Синт-Мартен, Словения, США, Таиланд, Турция, Уганда, Филиппины, Финляндия, Франция, Чешская Республика, Швейцария, Швеция, Шри-Ланка, Южная Корея, ЮАР, Япония.

За последние 4 недели в абсолютных значениях наибольшее число геномов варианта Delta депонировали Великобритания (39073), США (922), Германия (565), Сингапур (268), Испания (256), Португалия (237).

Наблюдается как увеличение, так и снижение доли вариантов вируса Delta, геномы которых депонированы в базе GISAID, к общему количеству выделенных штаммов.

На 25 июня 2021 года информация по числу депонированных геномов варианта Delta обновилась из следующих стран:

Австралия - стабилизация на уровне 27,0\%;

Австрия - увеличение от 4,0 до 6,2 \%;

Бангладеш - увеличение от 32,7 до 79,6\%;

Бахрейн -- увеличение от 0 до 83,3\%;

Бельгия - увеличение от 5,3 до $8,2 \%$;

Бразилия - уменьшение от 0,3 до 0\%;

Великобритания - увеличение от 77,0 до 81,4 \%;

Дания - уменьшение от 0,3 до 0\%;

Германия - увеличение от 2,8 до 7,2\%;

Индия - уменьшение от 74,7 до 19,2 \%;

Индонезия - увеличение от 64,8 до 67,2 \%;

Ирландия - увеличение от 2,1 до 4,8 \%;

Израиль - увеличение от 0 до 38,2\%;

Испания - увеличение от 8,8 до $14,1 \%$;

Италия - увеличение от 3,1 до 14,7\%;

Камбоджа - увеличение от 5,5 до 13,5\%;

Канада- уменьшение от 23,4 до $0 \%$;

Люксембург - уменьшение от 10,2 до $0 \%$;

Малайзия - уменьшение от 50,0 до 6,3\%;

Мексика - увеличение от 3,3 до 9,4\%;

Нидерланды - увеличение от 0,9 до 2,6\%;

Норвегия - уменьшение от 5,0 до 3,2\%;

Пакистан - уменьшение от 40,0 до $12,5 \%$;

Перу - увеличение от 0 до $33,3 \%$;

Польша - уменьшение от 1,5 до $0,8 \%$;

Португалия - стабилизация на уровне $45,6 \%$;

Румыния - увеличение от 0 до 2,9 \%;

Россия - увеличение от 62,1 до $64,9 \%$;

Сингапур - увеличение от 76,4 до 82,2 \%;

США - увеличение от 6,1 до $10,1 \%$;

Таиланд - уменьшение от 22,6 до 15,4\%;

Турция - уменьшение от 0,3 до $0 \%$; 
Франция - увеличение от 1,1 до 3,9\%;

Финляндия - увеличение от 55,2 до $0 \%$;

Швеция - увеличение от 0,3 до 10,2 \%;

Швейцария - увеличение от 1,3 до 4,3\%;

Шри Ланка - увеличение от 0 до 7,1\%;

Япония - стабилизация на

на уровне $22,8 \quad \%$. 


\section{Варианты вируса SARS-CoV-2 вызывающие интерес (VOI)}

В мире получили распространение другие варианты вируса SARSCOV-2, имеющие характерные мутации: вариант Epsilon (B.1.427/B.1.429), Eta (B.1.525), Theta GR/1092K.V1 (P.3), Iota GH/253G.V1 (B.1.526), Kappa G/452R.V3 (B.1.617.1), Lambda GR/452Q.V1 (C.37).

Информация по данным о депонированных геномах вируса VOI SARSCOV-2: Epsilon (B.1.427/B.1.429) и Eta (B.1.525) Theta (P.3), Iota (B.1.526), Kappa (B.1.617.1), Lambda (C.37) приведена в Приложении 1 таблице 2.

\section{Вариант Epsilon GH/452R.V1 (B.1.427/B.1.429)}

C 1 июля 2020 года в базе данных GISAID представлено 14482 генома вируса SARS-CoV-2 варианта VOI Epsilon GH/452R.V1 (B.1.427/B.1.429).

На сегодняшний день в базе данных GISAID зафиксировано депонирование варианта Epsilon (B.1.427/B.1.429) из 41 страны и территории: Австралия, Ангилья, Аруба, Аргентина, Барбадос, Бельгия, Великобритания, Германия, Гваделупа, Гуам, Дания, Израиль, Индия, Ирландия, Италия, Испания, Камбоджа, Камерун, Канада, Катар, Колумбия, Коста-Рика, Кюрасао, Мексика, Нидерланды, Норвегия, Северная Македония, Северные Марианские острова, Сингапур, США, Синт-Мартен, Тайвань, Турция, Филиппины, Финляндия, Франция, Швейцария, Швеция, Япония, Чили, Южная Корея.

На 25 июня 2021 года информация по числу депонированных геномов варианта Epsilon (B.1.429/B.1.427) обновилась из трех стран:

Мексика - уменьшение от 1 до $0,3 \%$;

США - уменьшение от 0,8 до $0,2 \%$.

Наблюдается уменьшение доли вариантов вируса Epsilon, геномы которых депонированы в базе GISAID, к общему количеству депонированных на неделе штаммов.

\section{Вариант VOI Eta G/484K.V3 (B.1.525)}

С декабря 2020 года в базе данных GISAID представлено 6895 генома вируса SARS-CoV-2 варианта Eta (B.1.525). За последнюю неделю в базу данных было депонирован еще 20 генома данного варианта вируса.

За прошедшую неделю в базу данных были депонированы геномы варианта Eta (B.1.525) из 4 новых стран - Кении, Мали, Сенегала, Эстонии. В итоге в базе данных GISAID зафиксировано депонирование варианта Eta (B.1.525) из 67 стран и территорий: Австралия, Австрия, Ангола, Аргентина, Бангладеш, Беларусь, Бельгия, Бразилия, Великобритания, Габон, Гамбия, Гана, Гваделупа, Гвинея, Германия, Греция, Дания, Израиль, Индия, Индонезия, Иордания, Ирландия, Испания, Италия, Канада, Катар, Камерун, Кения, Коста-Рика, Кот-д'Ивуар, Кувейта, Латвия, Ливия, Люксембург, Майотта, Малайзия, Мали, Мальта, Марокко, Нигер, Нигерия, Нидерланды, Норвегия, Польша, Португалия, Реюньон, Россия, Руанда, Сингапур, Сенегал, Словения, США, Таиланд, Тунис, Турция, Уганда, Финляндия, Филиппины, 
Франция, Швеция, Швейцария, Шри-Ланка, Эстония, Южная Корея, ЮАР, Южный Судан, Япония.

За последние 4 недели в абсолютных значениях наибольшее число геномов варианта Eta (B.1.525) депонировали Германия (37), Италия (22) и Франция (19). В странах мира наблюдается снижение и стабилизация доли вариантов вируса Eta геномы которых депонированы в базе GISAID, к общему количеству депонированных на неделе штаммов

На 25 июня 2021 года информация по числу депонированных геномов варианта Eta обновилась из следующих стран:

Великобритания - стабилизация на уровне $0,01 \%$;

Германия - увеличение от 0,2 до $0,5 \%$;

Италия - увеличение от 0,2 до $1,7 \%$;

Испания - увеличение от $0,3 \%$ до $0,5 \%$;

Кувейт - уменьшение от 40,0 до 31,2\%;

Люксембург - уменьшение от 0,6 до $0 \%$;

Португалия - увеличение от 0 до $0,6 \%$;

США - стабилизация на уровне $0,1 \%$;

Франция - уменьшение от 1,5 до $0,6 \%$;

Япония - увеличение от 0 до $0,9 \%$.

\section{Вариант VOI Theta GR/1092K.V1 (P.3)}

По состоянию на 25 июня 2021года в базе данных GISAID представлено 267 геномов варианта Theta (Р.3). В абсолютных значениях наибольшее число геномов данного варианта депонировали Филиппины (191).

В итоге в базе данных GISAID зафиксировано депонирование варианта Theta (Р.3) из 14 стран: Австралия, Ангола, Великобритания, Германия, Китай, Малайзия, Нидерланды, Новая Зеландия, Норвегия, Сингапур, США, Филиппины, Южная Корея, Япония.

\section{Вариант VOI Iota GH/253G.V1 (B.1.526)}

По состоянию на 25 июня 2021года в базе данных GISAID представлено 45303 генома варианта Iota (B.1.526). За последнюю неделю в базу данных было депонировано еще 3074 генома данного варианта вируса.

В абсолютных значениях наибольшее число геномов данного варианта депонировали США (44 122). За прошедшую неделю в базу данных были депонированы геномы варианта Iota из 18 новых стран.

В итоге в базе данных GISAID зафиксировано депонирование варианта Iota (B.1.526) из 53 стран и территорий: Ангилья, Аргентина, Аруба, Австралия, Австрия, Бельгия, Британские Виргинские острова, Великобритания, Венесуэла, Гана, Германия, Гваделупа, Гренада, Дания, Доминиканская Республика, Индия, Индонезия, Ирландия, Италия, Израиль, Испания, Канада, Каймановы острова, Китай, Колумбия, Коста-Рика, Кюрасао, Литва, Люк- 
сембург, Мексика, Нидерланды, Новая Зеландия, Перу, Польша, Португалия, Россия, Румыния, Сен-Мартен, Словения, Сингапур, Суринам, США, Турция, Чили, Швеция, Швейцария, Хорватия, Эквадор, Финляндия, Франция, Южная Корея, Ямайка, Япония.

\section{Вариант VOI Kappa G/452R.V3 (B.1.617.1)}

По состоянию на 25 июня 2021года в базе данных GISAID представлено 5167 геномов варианта Карра (В.1.617.1). За последнюю неделю в базу данных было депонировано еще 108 геномов данного варианта вируса. В абсолютных значениях наибольшее число геномов данного варианта депонировала Индия (3520).

В итоге в базе данных GISAID зафиксировано депонирование варианта Карра (В.1.617.1) из 50 стран и территорий: Ангола, Австралия, Австрия, Бахрейн, Бангладеш, Бельгия, Бразилия, Великобритания, Германия, Гана, Греция, Гваделупа, Дания, Камбоджа, Канада, Катар, Китай, Кюрасао, Индия, Индонезия, Ирландия, Италия, Иордания, Испания, Люксембург, Малави, Малайзия, Маврикий, Мексика, Непал, Нидерланды, Новая Зеландия, Норвегия, Португалия, Россия, Сингапур, Сен-Мартен, Словакия, Словения, США, Таиланд, Финляндия, Франция, Чехия, Швеция, Швейцария, Уганда, ЮАР, Южная Корея, Япония

\section{Вариант VOI Lambda GR/452Q.V1 (C.37)}

По состоянию на 25 июня 2021года в базе данных GISAID представлен 1881 геном варианта Lambda (C.37). За последнюю неделю в базу данных было депонировано еще 100 геномов данного варианта вируса. В абсолютных значениях наибольшее число геномов данного варианта депонировали Чили (670), США (520) и Перу (222).

В итоге в базе данных GISAID зафиксировано депонирование варианта Lambda (C.37) из 26 стран и территорий: Аруба, Аргентина, Австралия, Бразилия, Дания, Доминиканская Республика, Великобритания, Германия, Индия, Италия, Израиль, Испания, Камерун, Канада, Колумбия, Малави, Мексика, Нидерланды, Перу, Португалия, США, Уругвай, Швейцария, Чили, Франция, Эквадор. 
Таблица 1 - Количество депонированных геномов вариантов Alpha (B.1.1.7), Beta (B.1.351), Gamma (P.1) и Delta (B.1.617.2) варианта вируса SARS-CoV-2 в базе GISAID.

\begin{tabular}{|c|c|c|c|c|c|c|c|}
\hline \multirow[b]{2}{*}{$\begin{array}{c}\text { Страна } \\
\text { (тренд заболеваемости по } \\
\text { данным ЕСДС) }\end{array}$} & \multirow[b]{2}{*}{$\begin{array}{c}\text { Учреждение, проводившее се- } \\
\text { квенирование }\end{array}$} & \multicolumn{3}{|c|}{$\begin{array}{c}\text { Количество депонированных ге- } \\
\text { номов SARS-CoV-2 }\end{array}$} & \multicolumn{3}{|c|}{$\begin{array}{c}\text { В том числе количество геномов, } \\
\text { депонированных за последние } 4 \\
\text { недели } \\
(\mathbf{1 5 . 0 5 . 2 1}-\mathbf{1 1 . 0 6 . 2 1 )} \\
\end{array}$} \\
\hline & & $\begin{array}{c}\text { Варианты: } \\
\text { Alpha } \\
\text { (B.1.1.7) } \\
\text { Beta } \\
\text { (B.1.351) } \\
\text { Gamma (P.1) } \\
\text { Delta } \\
\text { (B.1.617.2) }\end{array}$ & $\begin{array}{l}\text { Bce } \\
\text { го }\end{array}$ & $\begin{array}{c}\text { Процент ге- } \\
\text { номов, отно- } \\
\text { сящихся к } \\
\text { варианту: } \\
\text { Alpha } \\
\text { (B.1.1.7) } \\
\text { Beta (B.1.351) } \\
\text { Gamma (P.1) } \\
\text { Delta } \\
\text { (B.1.617.2) }\end{array}$ & $\begin{array}{c}\text { Bapианты: } \\
\text { Alpha } \\
\text { (B.1.1.7) } \\
\text { Beta } \\
\text { (B.1.351) } \\
\text { Gamma } \\
\text { (P.1) } \\
\text { Delta } \\
\text { (B.1.617.2) }\end{array}$ & Всего & $\begin{array}{c}\text { Процент ге- } \\
\text { номов, отно- } \\
\text { сящихся к } \\
\text { варианту: } \\
\text { Alpha } \\
\text { (B.1.1.7) } \\
\text { Beta } \\
\text { (B.1.351) } \\
\text { Gamma (P.1) } \\
\text { Delta } \\
\text { (B.1.617.2) }\end{array}$ \\
\hline $\begin{array}{c}\text { Албания } \\
\text { (стабилизация } \\
\text { заболеваемости) }\end{array}$ & $\begin{array}{l}\text { Respiratory Virus Unit, National } \\
\text { Infection Service, Public Health } \\
\text { England }\end{array}$ & $\begin{array}{l}\text { Alpha }-27 \\
\text { Beta }-0 \\
\text { Gamma }-0 \\
\text { Delta }-0\end{array}$ & 30 & $\begin{array}{l}\text { Alpha }-90,0 \\
\text { Beta }-0 \\
\text { Gamma }-0 \\
\text { Delta }-0\end{array}$ & $\begin{array}{l}\text { Alpha }-0 \\
\text { Beta }-0 \\
\text { Gamma }-0 \\
\text { Delta }-0\end{array}$ & 0 & $\begin{array}{l}\text { Alpha }-0 \\
\text { Beta }-0 \\
\text { Gamma }-0 \\
\text { Delta }-0\end{array}$ \\
\hline $\begin{array}{c}\text { Ангилья } \\
\text { (стабилизация } \\
\text { заболеваемости) }\end{array}$ & $\begin{array}{l}\text { Carrington Lab, Department of } \\
\text { PreClinical Sciences, Faculty of } \\
\text { Medical Sciences, The University } \\
\text { of the West Indies }\end{array}$ & $\begin{array}{l}\text { Alpha }-2 \\
\text { Beta }-0 \\
\text { Gamma }-0 \\
\text { Delta }-1\end{array}$ & 5 & $\begin{array}{l}\text { Alpha }-40 \\
\text { Beta }-0 \\
\text { Gamma }-0 \\
\text { Delta }-20,0\end{array}$ & $\begin{array}{l}\text { Alpha }-0 \\
\text { Beta }-0 \\
\text { Gamma }-0 \\
\text { Delta }-0\end{array}$ & 0 & $\begin{array}{l}\text { Alpha }-0 \\
\text { Beta }-0 \\
\text { Gamma }-0 \\
\text { Delta }-0\end{array}$ \\
\hline
\end{tabular}




\begin{tabular}{|c|c|c|c|c|c|c|c|}
\hline $\begin{array}{c}\text { Ангола } \\
\text { (стабилизация } \\
\text { заболеваемости) }\end{array}$ & $\begin{array}{l}\text { KRISP, KZN Research Innovation } \\
\text { and Sequencing Platform }\end{array}$ & $\begin{array}{l}\text { Alpha }-53 \\
\text { Beta }-328 \\
\text { Gamma }-0 \\
\text { Delta }-4\end{array}$ & 663 & $\begin{array}{l}\text { Alpha }-8 \\
\text { Beta }-49,4 \\
\text { Gamma }-0 \\
\text { Delta }-0,6\end{array}$ & $\begin{array}{l}\text { Alpha }-0 \\
\text { Beta }-0 \\
\text { Gamma }-0 \\
\text { Delta }-0\end{array}$ & 0 & $\begin{array}{l}\text { Alpha }-0 \\
\text { Beta }-0 \\
\text { Gamma }-0 \\
\text { Delta }-0\end{array}$ \\
\hline $\begin{array}{c}\text { Аргентина } \\
\text { (снижение заболеваемо- } \\
\text { сти) }\end{array}$ & $\begin{array}{l}\text { Instituto Nacional EnfermedadesIn- } \\
\text { fecciosasC.G.Malbran }\end{array}$ & $\begin{array}{l}\text { Alpha }-123 \\
\text { Beta }-1 \\
\text { Gamma }-233 \\
\text { Delta }-1\end{array}$ & $\begin{array}{c}421 \\
4\end{array}$ & $\begin{array}{l}\text { Alpha }-2,9 \\
\text { Beta }-0,0 \\
\text { Gamma }-5,5 \\
\text { Delta }-0,0\end{array}$ & $\begin{array}{l}\text { Alpha }-0 \\
\text { Beta }-0 \\
\text { Gamma }-0 \\
\text { Delta }-0\end{array}$ & 0 & $\begin{array}{l}\text { Alpha }-0 \\
\text { Beta }-0 \\
\text { Gamma }-0 \\
\text { Delta }-0 \\
\end{array}$ \\
\hline $\begin{array}{c}\text { Армения } \\
\text { (стабилизация } \\
\text { заболеваемости) }\end{array}$ & $\begin{array}{l}\text { Institute of Molecular Biology } \\
\text { NAS RA, Republic of Armenia, } \\
\text { Department of Bioengineering, Bi- } \\
\text { oinformaticsInstitute and Molecular } \\
\text { Biology IBMPh RAU, Republic of } \\
\text { Armenia }\end{array}$ & $\begin{array}{l}\text { Alpha }-14 \\
\text { Beta }-0 \\
\text { Gamma }-0 \\
\text { Delta }-0\end{array}$ & 84 & $\begin{array}{l}\text { Alpha }-16,7 \\
\text { Beta }-0 \\
\text { Gamma }-0 \\
\text { Delta }-0\end{array}$ & $\begin{array}{l}\text { Alpha }-0 \\
\text { Beta }-0 \\
\text { Gamma }-0 \\
\text { Delta }-0\end{array}$ & 0 & $\begin{array}{l}\text { Alpha }-0 \\
\text { Beta }-0 \\
\text { Gamma }-0 \\
\text { Delta }-0\end{array}$ \\
\hline $\begin{array}{c}\text { Аруба } \\
\text { (стабилизация } \\
\text { заболеваемости) }\end{array}$ & $\begin{array}{l}\text { National Institute for Public Health } \\
\text { and the Environment (RIVM) }\end{array}$ & $\begin{array}{l}\text { Alpha }-533 \\
\text { Beta }-4 \\
\text { Gamma }-88 \\
\text { Delta }-3\end{array}$ & $\begin{array}{c}114 \\
2\end{array}$ & $\begin{array}{l}\text { Alpha }-46,7 \\
\text { Beta }-0,3 \\
\text { Gamma }-7,7 \\
\text { Delta }-0,3\end{array}$ & $\begin{array}{l}\text { Alpha }-5 \\
\text { Beta }-0 \\
\text { Gamma }-40 \\
\text { Delta }-0\end{array}$ & 134 & $\begin{array}{l}\text { Alpha }-3,7 \\
\text { Beta }-0 \\
\text { Gamma }-29,8 \\
\text { Delta }-0\end{array}$ \\
\hline $\begin{array}{c}\text { Австралия } \\
\text { (стабилизация } \\
\text { заболеваемости) }\end{array}$ & $\begin{array}{l}\text { NSW Health Pathology - Institute } \\
\text { of Clinical Pathology and Medical } \\
\text { Research; Westmead Hospital; } \\
\text { University of Sydney }\end{array}$ & $\begin{array}{l}\text { Alpha }-437 \\
\text { Beta }-62 \\
\text { Gamma }-7 \\
\text { Delta }-189\end{array}$ & $\begin{array}{c}181 \\
1\end{array}$ & $\begin{array}{l}\text { Alpha }-2,4 \\
\text { Beta }-3,4 \\
\text { Gamma }-0,0 \\
\text { Delta }-10,4\end{array}$ & $\begin{array}{l}\text { Alpha }-12 \\
\text { Beta }-7 \\
\text { Gamma }-0 \\
\text { Delta }-40\end{array}$ & 148 & $\begin{array}{l}\text { Alpha }-8,1 \\
\text { Beta }-4,7 \\
\text { Gamma }-0 \\
\text { Delta }-27\end{array}$ \\
\hline $\begin{array}{c}\text { Австрия } \\
\text { (снижение заболеваемо- } \\
\text { сти) }\end{array}$ & $\begin{array}{l}\text { Bergthaler laboratory, CeMM Re- } \\
\text { search Center for Molecular Medi- } \\
\text { cine of the Austrian Academy of } \\
\text { Sciences }\end{array}$ & $\begin{array}{l}\text { Alpha }-3219 \\
\text { Beta }-259 \\
\text { Gamma }-15 \\
\text { Delta }-22\end{array}$ & $\begin{array}{c}168 \\
40\end{array}$ & $\begin{array}{l}\text { Alpha }-19,1 \\
\text { Beta }-1,5 \\
\text { Gamma }-0,0 \\
\text { Delta }-0,1\end{array}$ & $\begin{array}{l}\text { Alpha }-52 \\
\text { Beta }-3 \\
\text { Gamma }-2 \\
\text { Delta }-14\end{array}$ & 227 & $\begin{array}{l}\text { Alpha }-22,9 \\
\text { Beta }-1,3 \\
\text { Gamma }-0,8 \\
\text { Delta }-6,1\end{array}$ \\
\hline $\begin{array}{c}\text { Азербайджан } \\
\text { (стабилизация заболевае- } \\
\text { мости) }\end{array}$ & $\begin{array}{l}\text { National Hematology and Transfu- } \\
\text { siology Center }\end{array}$ & $\begin{array}{l}\text { Alpha }-3 \\
\text { Beta }-0 \\
\text { Gamma }-0 \\
\text { Delta }-0 \\
\end{array}$ & 13 & $\begin{array}{l}\text { Alpha }-23,1 \\
\text { Beta }-0 \\
\text { Gamma }-0 \\
\text { Delta }-0\end{array}$ & $\begin{array}{l}\text { Alpha }-0 \\
\text { Beta }-0 \\
\text { Gamma }-0 \\
\text { Delta }-0 \\
\end{array}$ & 0 & $\begin{array}{l}\text { Alpha }-0 \\
\text { Beta }-0 \\
\text { Gamma }-0 \\
\text { Delta }-0 \\
\end{array}$ \\
\hline
\end{tabular}




\begin{tabular}{|c|c|c|c|c|c|c|c|}
\hline $\begin{array}{c}\text { Бахрейн } \\
\text { (снижение заболеваемо- } \\
\text { сти) }\end{array}$ & $\begin{array}{l}\text { Communicable Disease Laborato- } \\
\text { ry, Public Health Directorate }\end{array}$ & $\begin{array}{l}\text { Alpha }-14 \\
\text { Beta }-1 \\
\text { Gamma }-0 \\
\text { Delta }-27\end{array}$ & 218 & $\begin{array}{l}\text { Alpha }-6,4 \\
\text { Beta }-0,4 \\
\text { Gamma }-0 \\
\text { Delta }-12,3\end{array}$ & $\begin{array}{l}\text { Alpha }-1 \\
\text { Beta }-0 \\
\text { Gamma }-0 \\
\text { Delta }-5\end{array}$ & 6 & $\begin{array}{l}\text { Alpha }-16,7 \\
\text { Beta }-0 \\
\text { Gamma }-0 \\
\text { Delta }-83,3\end{array}$ \\
\hline $\begin{array}{c}\text { Бангладеш } \\
\text { (рост } \\
\text { заболеваемости) }\end{array}$ & Child Health Research Foundation & $\begin{array}{l}\text { Alpha }-90 \\
\text { Beta }-39 \\
\text { Gamma }-1 \\
\text { Delta }-89 \\
\end{array}$ & $\begin{array}{c}180 \\
5\end{array}$ & $\begin{array}{l}\text { Alpha }-4,9 \\
\text { Beta }-2,1 \\
\text { Gamma }-0 \\
\text { Delta }-5\end{array}$ & $\begin{array}{l}\text { Alpha }-2 \\
\text { Beta }-1 \\
\text { Gamma }-0 \\
\text { Delta }-43\end{array}$ & 54 & $\begin{array}{l}\text { Alpha }-3,7 \\
\text { Beta }-1,8 \\
\text { Gamma }-0 \\
\text { Delta }-79,6\end{array}$ \\
\hline $\begin{array}{c}\text { Барбадос } \\
\text { (стабилизация } \\
\text { заболеваемости) }\end{array}$ & $\begin{array}{l}\text { Carrington Lab, Department of } \\
\text { PreClinical Sciences, Building 36, } \\
\text { First Floor Biochemistry Unit, Fac- } \\
\text { ulty of Medical Sciences, The Uni- } \\
\text { versity of the West Indies }\end{array}$ & $\begin{array}{l}\text { Alpha }-16 \\
\text { Beta }-0 \\
\text { Gamma }-1 \\
\text { Delta }-3\end{array}$ & 23 & $\begin{array}{l}\text { Alpha }-69,6 \\
\text { Beta }-0 \\
\text { Gamma }-4,3 \\
\text { Delta }-13\end{array}$ & $\begin{array}{l}\text { Alpha }-0 \\
\text { Beta }-0 \\
\text { Gamma }-0 \\
\text { Delta }-0\end{array}$ & 0 & $\begin{array}{l}\text { Alpha }-0 \\
\text { Beta }-0 \\
\text { Gamma }-0 \\
\text { Delta }-0\end{array}$ \\
\hline $\begin{array}{c}\text { Беларусь } \\
\text { (стабилизация } \\
\text { заболеваемости) }\end{array}$ & $\begin{array}{l}\text { Laboratory for HIV and opportun- } \\
\text { istic infections diagnosis The Re- } \\
\text { publican Research and Practical } \\
\text { Center for Epidemiology and Mi- } \\
\text { crobiology (RRPCEM) }\end{array}$ & $\begin{array}{l}\text { Alpha }-3 \\
\text { Beta }-0 \\
\text { Gamma }-0 \\
\text { Delta }-0\end{array}$ & 47 & $\begin{array}{l}\text { Alpha }-6,4 \\
\text { Beta }-0 \\
\text { Gamma }-0 \\
\text { Delta }-0\end{array}$ & $\begin{array}{l}\text { Alpha }-0 \\
\text { Beta }-0 \\
\text { Gamma }-0 \\
\text { Delta }-0\end{array}$ & 0 & $\begin{array}{l}\text { Alpha }-0 \\
\text { Beta }-0 \\
\text { Gamma }-0 \\
\text { Delta }-0\end{array}$ \\
\hline $\begin{array}{c}\text { Бельгия } \\
\text { (снижение } \\
\text { заболеваемости) }\end{array}$ & $\begin{array}{l}\text { KU Leuven, Rega Institute, Clini- } \\
\text { cal and Epidemiological Virology }\end{array}$ & $\begin{array}{l}\text { Alpha - } \\
17055 \\
\text { Beta }-957 \\
\text { Gamma }- \\
1368 \\
\text { Delta }-368 \\
\end{array}$ & $\begin{array}{c}279 \\
10\end{array}$ & $\begin{array}{l}\text { Alpha }-61,1 \\
\text { Beta }-3,4 \\
\text { Gamma }-5 \\
\text { Delta }-1,3\end{array}$ & $\begin{array}{l}\text { Alpha }- \\
1506 \\
\text { Beta }-13 \\
\text { Gamma }- \\
172 \\
\text { Delta }-184\end{array}$ & 2254 & $\begin{array}{l}\text { Alpha }-66,8 \\
\text { Beta }-0,5 \\
\text { Gamma }-7,6 \\
\text { Delta }-8,1\end{array}$ \\
\hline $\begin{array}{c}\text { Белиз } \\
\text { (снижение } \\
\text { заболеваемости) }\end{array}$ & $\begin{array}{l}\text { Texas Children's Microbiome Cen- } \\
\text { ter }\end{array}$ & $\begin{array}{l}\text { Alpha }-1 \\
\text { Beta }-0 \\
\text { Gamma }-0 \\
\text { Delta }-0\end{array}$ & 52 & $\begin{array}{l}\text { Alpha }-2 \\
\text { Beta }-0 \\
\text { Gamma }-0 \\
\text { Delta }-0\end{array}$ & $\begin{array}{l}\text { Alpha }-0 \\
\text { Beta }-0 \\
\text { Gamma }-0 \\
\text { Delta }-0\end{array}$ & 0 & $\begin{array}{l}\text { Alpha }-0 \\
\text { Beta }-0 \\
\text { Gamma }-0 \\
\text { Delta }-0\end{array}$ \\
\hline Бермудские острова & $\begin{array}{l}\text { Respiratory Virus Unit, National } \\
\text { Infection Service, Public Health } \\
\text { England }\end{array}$ & $\begin{array}{l}\text { Alpha }-2 \\
\text { Beta }-0 \\
\text { Gamma }-0 \\
\text { Delta }-0\end{array}$ & 40 & $\begin{array}{l}\text { Alpha }-5 \\
\text { Beta }-0 \\
\text { Gamma }-0 \\
\text { Delta }-0\end{array}$ & $\begin{array}{l}\text { Alpha }-0 \\
\text { Beta }-0 \\
\text { Gamma }-0 \\
\text { Delta }-0\end{array}$ & 0 & $\begin{array}{l}\text { Alpha }-0 \\
\text { Beta }-0 \\
\text { Gamma }-0 \\
\text { Delta }-0\end{array}$ \\
\hline
\end{tabular}




\begin{tabular}{|c|c|c|c|c|c|c|c|}
\hline $\begin{array}{c}\text { Боливия } \\
\text { (стабилизация заболевае- } \\
\text { мости) }\end{array}$ & $\begin{array}{l}\text { Laboratory of Respiratory Viruses } \\
\text { and Measles, Oswaldo Cruz Insti- } \\
\text { tute, FIOCRUZ }\end{array}$ & $\begin{array}{l}\text { Alpha }-0 \\
\text { Beta }-0 \\
\text { Gamma }-14 \\
\text { Delta }-0\end{array}$ & 60 & $\begin{array}{l}\text { Alpha }-0 \\
\text { Beta }-0 \\
\text { Gamma }-23,3 \\
\text { Delta }-0\end{array}$ & $\begin{array}{l}\text { Alpha }-0 \\
\text { Beta }-0 \\
\text { Gamma }-0 \\
\text { Delta }-0\end{array}$ & 0 & $\begin{array}{l}\text { Alpha }-0 \\
\text { Beta }-0 \\
\text { Gamma }-0 \\
\text { Delta }-0\end{array}$ \\
\hline $\begin{array}{c}\text { Бонэйр } \\
\text { (снижение заболеваемо- } \\
\text { сти) }\end{array}$ & $\begin{array}{l}\text { National Institute for Public Health } \\
\text { and the Environment (RIVM) }\end{array}$ & $\begin{array}{l}\text { Alpha }-159 \\
\text { Beta }-0 \\
\text { Gamma }-0 \\
\text { Delta }-0\end{array}$ & 183 & $\begin{array}{l}\text { Alpha }-86,8 \\
\text { Beta }-0 \\
\text { Gamma }-0 \\
\text { Delta }-0\end{array}$ & $\begin{array}{l}\text { Alpha }-0 \\
\text { Beta }-0 \\
\text { Gamma }-0 \\
\text { Delta }-0\end{array}$ & 1 & $\begin{array}{l}\text { Alpha }-0 \\
\text { Beta }-0 \\
\text { Gamma }-0 \\
\text { Delta }-0 \\
\end{array}$ \\
\hline $\begin{array}{c}\text { Босния и Герцеговина } \\
\text { (снижение } \\
\text { заболеваемости) }\end{array}$ & $\begin{array}{l}\text { University of Sarajevo, Veterinary } \\
\text { Faculty, Laboratory for Molecular } \\
\text { Diagnostic and Research Laborato- } \\
\text { ry }\end{array}$ & $\begin{array}{l}\text { Alpha }-30 \\
\text { Beta }-0 \\
\text { Gamma }-0 \\
\text { Delta }-0\end{array}$ & 101 & $\begin{array}{l}\text { Alpha }-29,7 \\
\text { Beta }-0 \\
\text { Gamma }-0 \\
\text { Delta }-0\end{array}$ & $\begin{array}{l}\text { Alpha }-0 \\
\text { Beta }-0 \\
\text { Gamma }-0 \\
\text { Delta }-0\end{array}$ & 0 & $\begin{array}{l}\text { Alpha }-0 \\
\text { Beta }-0 \\
\text { Gamma }-0 \\
\text { Delta }-0\end{array}$ \\
\hline $\begin{array}{c}\text { Ботсвана } \\
\text { (рост заболеваемости) }\end{array}$ & $\begin{array}{l}\text { Botswana Institute for Technology } \\
\text { Research and Innovation }\end{array}$ & $\begin{array}{l}\text { Alpha }-0 \\
\text { Beta }-262 \\
\text { Gamma }-0 \\
\text { Delta }-5\end{array}$ & 385 & $\begin{array}{l}\text { Alpha }-0 \\
\text { Beta }-68,0 \\
\text { Gamma }-0 \\
\text { Delta }-1,3\end{array}$ & $\begin{array}{l}\text { Alpha }-0 \\
\text { Beta }-50 \\
\text { Gamma }-0 \\
\text { Delta }-0\end{array}$ & 56 & $\begin{array}{l}\text { Alpha }-0 \\
\text { Beta }-89,2 \\
\text { Gamma }-0 \\
\text { Delta }-0\end{array}$ \\
\hline $\begin{array}{c}\text { Бразилия } \\
\text { (рост } \\
\text { заболеваемости) }\end{array}$ & $\begin{array}{l}\text { Instituto Adolfo Lutz, Interdicipli- } \\
\text { nary Procedures Center, Strategic } \\
\text { Laboratory }\end{array}$ & $\begin{array}{l}\text { Alpha }-441 \\
\text { Beta - 5 } \\
\text { Gamma - } \\
10513 \\
\text { Delta - } 12 \\
\end{array}$ & $\begin{array}{c}186 \\
20\end{array}$ & $\begin{array}{l}\text { Alpha }-2,3 \\
\text { Beta }-0,0 \\
\text { Gamma }-56,4 \\
\text { Delta }-0,0\end{array}$ & $\begin{array}{l}\text { Alpha }-6 \\
\text { Beta }-0 \\
\text { Gamma - } \\
204 \\
\text { Delta }-0\end{array}$ & 499 & $\begin{array}{l}\text { Alpha }-1,2 \\
\text { Beta }-0 \\
\text { Gamma }-40,8 \\
\text { Delta }-0\end{array}$ \\
\hline $\begin{array}{c}\text { Бруней } \\
\text { (стабилизация } \\
\text { заболеваемости) }\end{array}$ & $\begin{array}{l}\text { National Public Health Laboratory, } \\
\text { National Centre for Infectious Dis- } \\
\text { eases (National Virology Reference } \\
\text { Laboratory) }\end{array}$ & $\begin{array}{l}\text { Alpha }-0 \\
\text { Beta }-1 \\
\text { Gamma }-0 \\
\text { Delta }-0 \\
\end{array}$ & 10 & $\begin{array}{l}\text { Alpha }-0 \\
\text { Beta }-10,0 \\
\text { Gamma }-0 \\
\text { Delta }-0 \\
\end{array}$ & $\begin{array}{l}\text { Alpha }-0 \\
\text { Beta }-0 \\
\text { Gamma }-0 \\
\text { Delta }-0 \\
\end{array}$ & 0 & $\begin{array}{l}\text { Alpha }-0 \\
\text { Beta }-0 \\
\text { Gamma }-0 \\
\text { Delta }-0 \\
\end{array}$ \\
\hline $\begin{array}{c}\text { Болгария } \\
\text { (снижение } \\
\text { заболеваемости) }\end{array}$ & $\begin{array}{l}\text { National Center of Infectious and } \\
\text { Parasitic Diseases }\end{array}$ & $\begin{array}{l}\text { Alpha }-2755 \\
\text { Beta }-0 \\
\text { Gamma }-0 \\
\text { Delta }-1\end{array}$ & $\begin{array}{c}306 \\
8\end{array}$ & $\begin{array}{l}\text { Alpha }-89,8 \\
\text { Beta }-0 \\
\text { Gamma }-0 \\
\text { Delta }-0,0\end{array}$ & $\begin{array}{l}\text { Alpha }-0 \\
\text { Beta }-0 \\
\text { Gamma }-0 \\
\text { Delta }-0\end{array}$ & 0 & $\begin{array}{l}\text { Alpha }-0 \\
\text { Beta }-0 \\
\text { Gamma }-0 \\
\text { Delta }-0\end{array}$ \\
\hline $\begin{array}{c}\text { Буркина Фасо } \\
\text { (стабилизация } \\
\text { заболеваемости) }\end{array}$ & $\begin{array}{l}\text { Laboratoire bacteriologie virologie } \\
\text { CHUSS }\end{array}$ & $\begin{array}{l}\text { Alpha }-3 \\
\text { Beta }-0 \\
\text { Gamma }-0 \\
\text { Delta }-0\end{array}$ & 208 & $\begin{array}{l}\text { Alpha }-1,4 \\
\text { Beta }-0 \\
\text { Gamma }-0 \\
\text { Delta }-0\end{array}$ & $\begin{array}{l}\text { Alpha }-0 \\
\text { Beta }-0 \\
\text { Gamma }-0 \\
\text { Delta }-0\end{array}$ & 0 & $\begin{array}{l}\text { Alpha -0 } \\
\text { Beta }-0 \\
\text { Gamma }-0 \\
\text { Delta }-0\end{array}$ \\
\hline
\end{tabular}




\begin{tabular}{|c|c|c|c|c|c|c|c|}
\hline $\begin{array}{c}\text { Великобритания } \\
\text { (рост заболеваемости) }\end{array}$ & $\begin{array}{l}\text { COVID-19 Genomics UK (COG- } \\
\text { UK) Consortium. } \\
\text { Wellcome Sanger Institute for the } \\
\text { COVID-19 Genomics UK (COG- } \\
\text { UK) consortium. }\end{array}$ & $\begin{array}{l}\text { Alpha }- \\
255048 \\
\text { Beta }-652 \\
\text { Gamma }-159 \\
\text { Delta }-56100\end{array}$ & $\begin{array}{l}476 \\
400\end{array}$ & $\begin{array}{l}\text { Alpha }-54,8 \\
\text { Beta }-0,1 \\
\text { Gamma }-0,0 \\
\text { Delta }-0,01\end{array}$ & $\begin{array}{l}\text { Alpha }- \\
4808 \\
\text { Beta }-23 \\
\text { Gamma }-16 \\
\text { Delta - } \\
39073\end{array}$ & 47980 & $\begin{array}{l}\text { Alpha }-10 \\
\text { Beta }-0 \\
\text { Gamma }-0 \\
\text { Delta }-81,4\end{array}$ \\
\hline $\begin{array}{c}\text { Венгрия } \\
\text { (снижение } \\
\text { заболеваемости) }\end{array}$ & $\begin{array}{l}\text { National Laboratory of Virology, } \\
\text { Szentágothai Research Centre }\end{array}$ & $\begin{array}{l}\text { Alpha }-29 \\
\text { Beta }-0 \\
\text { Gamma }-0 \\
\text { Delta }-0\end{array}$ & 435 & $\begin{array}{l}\text { Alpha }-6,7 \\
\text { Beta }-0 \\
\text { Gamma }-0 \\
\text { Delta }-0\end{array}$ & $\begin{array}{l}\text { Alpha }-0 \\
\text { Beta }-0 \\
\text { Gamma }-0 \\
\text { Delta }-0\end{array}$ & 0 & $\begin{array}{l}\text { Alpha }-0 \\
\text { Beta }-0 \\
\text { Gamma }-0 \\
\text { Delta }-0\end{array}$ \\
\hline $\begin{array}{c}\text { Венесуэла } \\
\text { (стабилизация } \\
\text { заболеваемости) }\end{array}$ & Laboratorio de Virología Molecular & $\begin{array}{l}\text { Alpha }-0 \\
\text { Beta }-0 \\
\text { Gamma }-17 \\
\text { Delta }-0\end{array}$ & 148 & $\begin{array}{l}\text { Alpha - } \\
\text { Beta }-0 \\
\text { Gamma }-11,4 \\
\text { Delta }-0\end{array}$ & $\begin{array}{l}\text { Alpha }-0 \\
\text { Beta }-0 \\
\text { Gamma }-0 \\
\text { Delta }-0\end{array}$ & 1 & $\begin{array}{l}\text { Alpha }-0 \\
\text { Beta }-0 \\
\text { Gamma }-0 \\
\text { Delta }-0\end{array}$ \\
\hline $\begin{array}{c}\text { Вьетнам } \\
\text { (стабилизация заболевае- } \\
\text { мости) }\end{array}$ & $\begin{array}{l}\text { National Influenza Center, National } \\
\text { Institute of Hygiene and Epidemi- } \\
\text { ology (NIHE) }\end{array}$ & $\begin{array}{l}\text { Alpha }-25 \\
\text { Beta }-0 \\
\text { Gamma }-0 \\
\text { Delta }-72\end{array}$ & 185 & $\begin{array}{l}\text { Alpha }-13,6 \\
\text { Beta }-0 \\
\text { Gamma }-0 \\
\text { Delta }-39,0\end{array}$ & $\begin{array}{l}\text { Alpha }-0 \\
\text { Beta }-0 \\
\text { Gamma }-0 \\
\text { Delta }-0\end{array}$ & 0 & $\begin{array}{l}\text { Alpha }-0 \\
\text { Beta }-0 \\
\text { Gamma }-0 \\
\text { Delta }-0\end{array}$ \\
\hline $\begin{array}{c}\text { Габон } \\
\text { (снижение } \\
\text { заболеваемости) }\end{array}$ & $\begin{array}{l}\text { Centre de recherches médicales de } \\
\text { Lambaréné (CERMEL) }\end{array}$ & $\begin{array}{l}\text { Alpha }-35 \\
\text { Beta }-4 \\
\text { Gamma }-0 \\
\text { Delta }-0 \\
\end{array}$ & 205 & $\begin{array}{l}\text { Alpha }-17,0 \\
\text { Beta - } 2 \\
\text { Gamma }-0 \\
\text { Delta }-0 \\
\end{array}$ & $\begin{array}{l}\text { Alpha }-0 \\
\text { Beta }-0 \\
\text { Gamma }-0 \\
\text { Delta }-0 \\
\end{array}$ & 0 & $\begin{array}{l}\text { Alpha }-0 \\
\text { Beta }-0 \\
\text { Gamma }-0 \\
\text { Delta }-0\end{array}$ \\
\hline $\begin{array}{c}\text { Гаити } \\
\text { (стабилизация } \\
\text { заболеваемости) }\end{array}$ & $\begin{array}{l}\text { Laboratoire National de Santé } \\
\text { Publique - LNSP (HAITI - LNSP) }\end{array}$ & $\begin{array}{l}\text { Alpha }-1 \\
\text { Beta }-5 \\
\text { Gamma }-47 \\
\text { Delta }-0\end{array}$ & 79 & $\begin{array}{l}\text { Alpha }-1,3 \\
\text { Beta }-2,4 \\
\text { Gamma }-59,5 \\
\text { Delta }-0\end{array}$ & $\begin{array}{l}\text { Alpha }-0 \\
\text { Beta }-0 \\
\text { Gamma }-0 \\
\text { Delta }-0\end{array}$ & 0 & $\begin{array}{l}\text { Alpha }-0 \\
\text { Beta }-0 \\
\text { Gamma }-0 \\
\text { Delta }-0\end{array}$ \\
\hline $\begin{array}{c}\text { Гайана } \\
\text { (стабилизация } \\
\text { заболеваемости) }\end{array}$ & $\begin{array}{l}\text { CNR Virus des Infections Res- } \\
\text { piratoires - France SUD }\end{array}$ & $\begin{array}{l}\text { Alpha }-0 \\
\text { Beta }-0 \\
\text { Gamma }-1 \\
\text { Delta }-0\end{array}$ & 11 & $\begin{array}{l}\text { Alpha }-0 \\
\text { Beta }-0 \\
\text { Gamma }-9,1 \\
\text { Delta }-0\end{array}$ & $\begin{array}{l}\text { Alpha }-0 \\
\text { Beta }-0 \\
\text { Gamma }-0 \\
\text { Delta }-0\end{array}$ & 0 & $\begin{array}{l}\text { Alpha }-0 \\
\text { Beta }-0 \\
\text { Gamma }-0 \\
\text { Delta }-0\end{array}$ \\
\hline
\end{tabular}




\begin{tabular}{|c|c|c|c|c|c|c|c|}
\hline $\begin{array}{c}\text { Гамбия } \\
\text { (стабилизация } \\
\text { заболеваемости) }\end{array}$ & MRCG at LSHTM Genomics lab & $\begin{array}{l}\text { Alpha }-53 \\
\text { Beta }-0 \\
\text { Gamma }-0 \\
\text { Delta }-0\end{array}$ & 472 & $\begin{array}{l}\text { Alpha }-11,2 \\
\text { Beta }-0 \\
\text { Gamma }-0 \\
\text { Delta }-0\end{array}$ & $\begin{array}{l}\text { Alpha }-0 \\
\text { Beta }-0 \\
\text { Gamma }-0 \\
\text { Delta }-0\end{array}$ & 0 & $\begin{array}{l}\text { Alpha }-0 \\
\text { Beta }-0 \\
\text { Gamma }-0 \\
\text { Delta }-0\end{array}$ \\
\hline $\begin{array}{c}\text { Гана } \\
\text { (стабилизация заболевае- } \\
\text { мости) }\end{array}$ & $\begin{array}{l}\text { Department of Biochemistry, Cell } \\
\text { and Molecular Biology, West Afri- } \\
\text { can Centre for Cell Biology of In- } \\
\text { fectious Pathogens (WACCBIP), } \\
\text { University of Ghana }\end{array}$ & $\begin{array}{l}\text { Alpha }-294 \\
\text { Beta }-12 \\
\text { Gamma }-0 \\
\text { Delta }-2\end{array}$ & 698 & $\begin{array}{l}\text { Alpha }-42,1 \\
\text { Beta }-1,7 \\
\text { Gamma }-0 \\
\text { Delta }-0,3\end{array}$ & $\begin{array}{l}\text { Alpha }-0 \\
\text { Beta }-0 \\
\text { Gamma }-0 \\
\text { Delta }-0\end{array}$ & 0 & $\begin{array}{l}\text { Alpha }-0 \\
\text { Beta }-0 \\
\text { Gamma }-0 \\
\text { Delta }-0\end{array}$ \\
\hline Гваделупа & $\begin{array}{l}\text { National Reference Center for Vi- } \\
\text { ruses of Respiratory Infections, In- } \\
\text { stitut Pasteur, Paris }\end{array}$ & $\begin{array}{l}\text { Alpha }-63 \\
\text { Beta }-3 \\
\text { Gamma }-0 \\
\text { Delta }-3\end{array}$ & 145 & $\begin{array}{l}\text { Alpha }-43,4 \\
\text { Beta }-2,0 \\
\text { Gamma }-0 \\
\text { Delta }-2,0\end{array}$ & $\begin{array}{l}\text { Alpha }-2 \\
\text { Beta }-0 \\
\text { Gamma }-0 \\
\text { Delta }-0\end{array}$ & 18 & $\begin{array}{l}\text { Alpha }-11,1 \\
\text { Beta }-0 \\
\text { Gamma }-0 \\
\text { Delta }-0\end{array}$ \\
\hline $\begin{array}{c}\text { Гватемала } \\
\text { (стабилизация заболевае- } \\
\text { мости) }\end{array}$ & $\begin{array}{l}\text { Asociación de Salud Inte- } \\
\text { gral/Clínica Familiar Luis Ángel } \\
\text { García }\end{array}$ & $\begin{array}{l}\text { Alpha }-1 \\
\text { Beta }-0 \\
\text { Gamma }-0 \\
\text { Delta }-0\end{array}$ & 41 & $\begin{array}{l}\text { Alpha }-2,4 \\
\text { Beta }-0 \\
\text { Gamma }-0 \\
\text { Delta }-0\end{array}$ & $\begin{array}{l}\text { Alpha }-0 \\
\text { Beta }-0 \\
\text { Gamma }-0 \\
\text { Delta }-0\end{array}$ & 0 & $\begin{array}{l}\text { Alpha }-0 \\
\text { Beta }-0 \\
\text { Gamma }-0 \\
\text { Delta }-0\end{array}$ \\
\hline $\begin{array}{c}\text { Гвинея } \\
\text { (стабилизация } \\
\text { заболеваемости) }\end{array}$ & $\begin{array}{l}\text { Centre de Recherche et de For- } \\
\text { mation en Infectiologie Guinée }\end{array}$ & $\begin{array}{l}\text { Alpha }-12 \\
\text { Beta }-0 \\
\text { Gamma }-0 \\
\text { Delta }-0\end{array}$ & 40 & $\begin{array}{l}\text { Alpha }-30 \\
\text { Beta }-0 \\
\text { Gamma }-0 \\
\text { Delta }-0\end{array}$ & $\begin{array}{l}\text { Alpha }-0 \\
\text { Beta }-0 \\
\text { Gamma }-0 \\
\text { Delta }-0\end{array}$ & 0 & $\begin{array}{l}\text { Alpha }-0 \\
\text { Beta }-0 \\
\text { Gamma }-0 \\
\text { Delta }-0\end{array}$ \\
\hline $\begin{array}{c}\text { Гвинея Биссау } \\
\text { (стабилизация } \\
\text { заболеваемости) }\end{array}$ & MRCG at LSHTM, Genomics lab & $\begin{array}{l}\text { Alpha }-33 \\
\text { Beta }-1 \\
\text { Gamma }-0 \\
\text { Delta }-0\end{array}$ & 48 & $\begin{array}{l}\text { Alpha }-68,7 \\
\text { Beta }-2,0 \\
\text { Gamma }-0 \\
\text { Delta }-0\end{array}$ & $\begin{array}{l}\text { Alpha }-0 \\
\text { Beta }-0 \\
\text { Gamma }-0 \\
\text { Delta }-0\end{array}$ & 0 & $\begin{array}{l}\text { Alpha }-0 \\
\text { Beta }-0 \\
\text { Gamma }-0 \\
\text { Delta }-0\end{array}$ \\
\hline $\begin{array}{c}\text { Германия } \\
\text { (снижение заболеваемо- } \\
\text { сти) }\end{array}$ & $\begin{array}{l}\text { CharitéUniversitätsmedizin Berlin, } \\
\text { InstitutfürVirologie. } \\
\text { Institute of infectious medicine \& } \\
\text { hospital hygiene, CaSe-Group. }\end{array}$ & $\begin{array}{l}\text { Alpha - } \\
99304 \\
\text { Beta }-2154 \\
\text { Gamma }-259 \\
\text { Delta }-1278\end{array}$ & $\begin{array}{l}134 \\
500\end{array}$ & $\begin{array}{l}\text { Alpha }-73,8 \\
\text { Beta }-1,6 \\
\text { Gamma }-0,2 \\
\text { Delta }-1\end{array}$ & $\begin{array}{l}\text { Alpha }- \\
5180 \\
\text { Beta }-33 \\
\text { Gamma }-64 \\
\text { Delta }-565\end{array}$ & 7877 & $\begin{array}{l}\text { Alpha }-65,7 \\
\text { Beta }-0,4 \\
\text { Gamma }-0,8 \\
\text { Delta }-7,1\end{array}$ \\
\hline
\end{tabular}




\begin{tabular}{|c|c|c|c|c|c|c|c|}
\hline $\begin{array}{c}\text { Гибралтар } \\
\text { (рост заболеваемости) }\end{array}$ & $\begin{array}{l}\text { Respiratory Virus Unit, National } \\
\text { Infection Service, Public Health } \\
\text { England }\end{array}$ & $\begin{array}{l}\text { Alpha }-130 \\
\text { Beta }-0 \\
\text { Gamma }-0 \\
\text { Delta }-0\end{array}$ & 482 & $\begin{array}{l}\text { Alpha }-27,0 \\
\text { Beta }-0 \\
\text { Gamma }-0 \\
\text { Delta }-0\end{array}$ & $\begin{array}{l}\text { Alpha }-0 \\
\text { Beta }-0 \\
\text { Gamma }-0 \\
\text { Delta }-0\end{array}$ & 0 & $\begin{array}{l}\text { Alpha }-0 \\
\text { Beta }-0 \\
\text { Gamma }-0 \\
\text { Delta }-0\end{array}$ \\
\hline $\begin{array}{c}\text { Гренада } \\
\text { (стабилизация } \\
\text { заболеваемости) }\end{array}$ & $\begin{array}{l}\text { The Caribbean Public Health Agen- } \\
\text { cy }\end{array}$ & $\begin{array}{l}\text { Alpha }-2 \\
\text { Beta }-0 \\
\text { Gamma }-0 \\
\text { Delta }-0\end{array}$ & 7 & $\begin{array}{l}\text { Alpha }-28,5 \\
\text { Beta }-0 \\
\text { Gamma }-0 \\
\text { Delta }-0\end{array}$ & $\begin{array}{l}\text { Alpha }-0 \\
\text { Beta }-0 \\
\text { Gamma }-0 \\
\text { Delta }-0\end{array}$ & 0 & $\begin{array}{l}\text { Alpha }-0 \\
\text { Beta }-0 \\
\text { Gamma }-0 \\
\text { Delta }-0\end{array}$ \\
\hline $\begin{array}{c}\text { Греция } \\
\text { (снижение заболеваемо- } \\
\text { сти) }\end{array}$ & $\begin{array}{l}\text { Greek Genome Center, Biomedical } \\
\text { Research Foundation of the Acad- } \\
\text { emy of Athens (BRFAA) }\end{array}$ & $\begin{array}{l}\text { Alpha }-5338 \\
\text { Beta }-22 \\
\text { Gamma }-0 \\
\text { Delta }-10\end{array}$ & $\begin{array}{c}774 \\
2\end{array}$ & $\begin{array}{l}\text { Alpha }-69 \\
\text { Beta }-0,3 \\
\text { Gamma }-0 \\
\text { Delta }-0,1\end{array}$ & $\begin{array}{l}\text { Alpha }-41 \\
\text { Beta }-0 \\
\text { Gamma }-0 \\
\text { Delta }-0\end{array}$ & 96 & $\begin{array}{l}\text { Alpha }-42,7 \\
\text { Beta }-0 \\
\text { Gamma }-0 \\
\text { Delta }-0\end{array}$ \\
\hline $\begin{array}{c}\text { Грузия } \\
\text { (снижение заболеваемо- } \\
\text { сти) }\end{array}$ & $\begin{array}{l}\text { Department for Virology, Molecu- } \\
\text { lar Biology and Genome Research, } \\
\text { R. G. Lugar Center for Public } \\
\text { Health Research, National Center } \\
\text { for Disease Control and Public } \\
\text { Health (NCDC) of Georgia. }\end{array}$ & $\begin{array}{l}\text { Alpha }-23 \\
\text { Beta }-0 \\
\text { Gamma }-0 \\
\text { Delta }-4\end{array}$ & 69 & $\begin{array}{l}\text { Alpha }-33,3 \\
\text { Beta }-0 \\
\text { Gamma }-0 \\
\text { Delta }-5,8\end{array}$ & $\begin{array}{l}\text { Alpha }-0 \\
\text { Beta }-0 \\
\text { Gamma }-0 \\
\text { Delta }-0\end{array}$ & 0 & $\begin{array}{l}\text { Alpha }-0 \\
\text { Beta }-0 \\
\text { Gamma }-0 \\
\text { Delta }-0\end{array}$ \\
\hline $\begin{array}{c}\text { Гуам } \\
\text { (стабилизация } \\
\text { заболеваемости) }\end{array}$ & $\begin{array}{l}\text { Centers for Disease Control and } \\
\text { Preven-tion Division of Viral Dis- } \\
\text { eases, Pathogen Discovery }\end{array}$ & $\begin{array}{l}\text { Alpha }-23 \\
\text { Beta }-2 \\
\text { Gamma }-0 \\
\text { Delta }-1 \\
\end{array}$ & 60 & $\begin{array}{l}\text { Alpha }-38,3 \\
\text { Beta }-3,3 \\
\text { Gamma }-0 \\
\text { Delta }-1,7\end{array}$ & $\begin{array}{l}\text { Alpha }-0 \\
\text { Beta }-0 \\
\text { Gamma }-0 \\
\text { Delta }-0\end{array}$ & 0 & $\begin{array}{l}\text { Alpha }-0 \\
\text { Beta }-0 \\
\text { Gamma }-0 \\
\text { Delta }-0 \\
\end{array}$ \\
\hline $\begin{array}{c}\text { Дания } \\
\text { (снижение заболеваемо- } \\
\text { сти) }\end{array}$ & $\begin{array}{l}\text { Albertsen lab, Department of } \\
\text { Chemistry and Bioscience, Aalborg } \\
\text { University. } \\
\text { Department of Virus and Microbio- } \\
\text { logical Special Diagnostics, Statens } \\
\text { Serum Institut. }\end{array}$ & $\begin{array}{l}\text { Alpha - } \\
49595 \\
\text { Beta }-105 \\
\text { Gamma }-31 \\
\text { Delta }-97\end{array}$ & $\begin{array}{l}105 \\
600\end{array}$ & $\begin{array}{l}\text { Alpha }-47,0 \\
\text { Beta }-0,1 \\
\text { Gamma }-0,03 \\
\text { Delta }-0\end{array}$ & $\begin{array}{l}\text { Alpha - } \\
7095 \\
\text { Beta }-0 \\
\text { Gamma }-0 \\
\text { Delta }-0\end{array}$ & 7327 & $\begin{array}{l}\text { Alpha }-96,84 \\
\text { Beta }-0 \\
\text { Gamma }-0 \\
\text { Delta }-0\end{array}$ \\
\hline $\begin{array}{c}\text { ДР Конго } \\
\text { (стабилизация заболевае- } \\
\text { мости) }\end{array}$ & $\begin{array}{l}\text { Pathogen Sequencing Lab, National } \\
\text { Institute for Biomedical Research } \\
\text { (INRB) }\end{array}$ & $\begin{array}{l}\text { Alpha }-8 \\
\text { Beta }-13 \\
\text { Gamma }-0 \\
\text { Delta }-6\end{array}$ & 387 & $\begin{array}{l}\text { Alpha }-2,0 \\
\text { Beta }-3,4 \\
\text { Gamma }-0 \\
\text { Delta }-1,6\end{array}$ & $\begin{array}{l}\text { Alpha }-0 \\
\text { Beta }-0 \\
\text { Gamma }-0 \\
\text { Delta }-0\end{array}$ & 0 & $\begin{array}{l}\text { Alpha }-0 \\
\text { Beta }-0 \\
\text { Gamma }-0 \\
\text { Delta }-0\end{array}$ \\
\hline
\end{tabular}




\begin{tabular}{|c|c|c|c|c|c|c|c|}
\hline $\begin{array}{c}\text { Доминика } \\
\text { (стабилизация } \\
\text { заболеваемости) }\end{array}$ & $\begin{array}{l}\text { Carrington Lab, Department of } \\
\text { PreClinical Sciences, Faculty of } \\
\text { Medical Sciences, The University } \\
\text { of the West Indies, St Augustine } \\
\text { Campus }\end{array}$ & $\begin{array}{l}\text { Alpha }-7 \\
\text { Beta }- \\
\text { Gamma }-0 \\
\text { Delta }-\end{array}$ & 9 & $\begin{array}{l}\text { Alpha }-77,8 \\
\text { Beta }- \\
\text { Gamma }-0 \\
\text { Delta }-\end{array}$ & $\begin{array}{l}\text { Alpha }-0 \\
\text { Beta }-0 \\
\text { Gamma }-0 \\
\text { Delta }-0\end{array}$ & 0 & $\begin{array}{l}\text { Alpha }-0 \\
\text { Beta }-0 \\
\text { Gamma }-0 \\
\text { Delta }-0\end{array}$ \\
\hline $\begin{array}{c}\text { Доминиканская Респуб- } \\
\text { лика } \\
\text { (стабилизация } \\
\text { заболеваемости) }\end{array}$ & $\begin{array}{l}\text { Respiratory Viruses Branch, Cen- } \\
\text { ters for Disease Control and Pre- } \\
\text { vention, USA }\end{array}$ & $\begin{array}{l}\text { Alpha }-0 \\
\text { Beta }-0 \\
\text { Gamma }-5 \\
\text { Delta }-0\end{array}$ & 79 & $\begin{array}{l}\text { Alpha }-8,8 \\
\text { Beta }-0 \\
\text { Gamma }-5,7 \\
\text { Delta }-0\end{array}$ & $\begin{array}{l}\text { Alpha }-0 \\
\text { Beta }-0 \\
\text { Gamma }-1 \\
\text { Delta }-0\end{array}$ & 3 & $\begin{array}{l}\text { Alpha }-0 \\
\text { Beta }-0 \\
\text { Gamma }-33,3 \\
\text { Delta }-0\end{array}$ \\
\hline $\begin{array}{c}\text { Египет } \\
\text { (стабилизация } \\
\text { заболеваемости) }\end{array}$ & $\begin{array}{l}\text { Main Chemical Laboratories Egypt } \\
\text { Army }\end{array}$ & $\begin{array}{l}\text { Alpha }-13 \\
\text { Beta }-0 \\
\text { Gamma }-0 \\
\text { Delta }-0 \\
\end{array}$ & 957 & $\begin{array}{l}\text { Alpha }-1,3 \\
\text { Beta }-0 \\
\text { Gamma }-0 \\
\text { Delta }-0 \\
\end{array}$ & $\begin{array}{l}\text { Alpha }-0 \\
\text { Beta }-0 \\
\text { Gamma }-0 \\
\text { Delta }-0 \\
\end{array}$ & 0 & $\begin{array}{l}\text { Alpha }-0 \\
\text { Beta }-0 \\
\text { Gamma }-0 \\
\text { Delta }-0 \\
\end{array}$ \\
\hline $\begin{array}{c}\text { Замбия } \\
\text { (рост заболеваемости) }\end{array}$ & $\begin{array}{l}\text { University of Zambia, School of } \\
\text { Veterinary Medicine }\end{array}$ & $\begin{array}{l}\text { Alpha }-0 \\
\text { Beta }-33 \\
\text { Gamma }-0 \\
\text { Delta }-0\end{array}$ & 223 & $\begin{array}{l}\text { Alpha }-0 \\
\text { Beta }-14,7 \\
\text { Gamma }-0 \\
\text { Delta }-0\end{array}$ & $\begin{array}{l}\text { Alpha }-0 \\
\text { Beta }-0 \\
\text { Gamma }-0 \\
\text { Delta }-0\end{array}$ & 0 & $\begin{array}{l}\text { Alpha }-0 \\
\text { Beta }-0 \\
\text { Gamma }-0 \\
\text { Delta }-0\end{array}$ \\
\hline $\begin{array}{c}\text { Зимбабве } \\
\text { (рост заболеваемости) }\end{array}$ & $\begin{array}{l}\text { National Microbiology Reference } \\
\text { Laboratory (Quadram Institute Bio- } \\
\text { science) }\end{array}$ & $\begin{array}{l}\text { Alpha }-0 \\
\text { Beta }-331 \\
\text { Gamma }-0 \\
\text { Delta }-0\end{array}$ & 558 & $\begin{array}{l}\text { Alpha }-0 \\
\text { Beta }-59,3 \\
\text { Gamma }-0 \\
\text { Delta }-0\end{array}$ & $\begin{array}{l}\text { Alpha }-0 \\
\text { Beta }-0 \\
\text { Gamma }-0 \\
\text { Delta }-0\end{array}$ & 0 & $\begin{array}{l}\text { Alpha }-0 \\
\text { Beta }-0 \\
\text { Gamma }-0 \\
\text { Delta }-0\end{array}$ \\
\hline $\begin{array}{c}\text { Израиль } \\
\text { (рост заболеваемости) }\end{array}$ & $\begin{array}{l}\text { Central Virology Laboratory, Israel } \\
\text { Ministry of Health }\end{array}$ & $\begin{array}{l}\text { Alpha }-7918 \\
\text { Beta }-240 \\
\text { Gamma }-11 \\
\text { Delta }-113\end{array}$ & $\begin{array}{c}121 \\
70\end{array}$ & $\begin{array}{l}\text { Alpha }-65 \\
\text { Beta }-1,9 \\
\text { Gamma }-0,1 \\
\text { Delta }-1\end{array}$ & $\begin{array}{l}\text { Alpha }-28 \\
\text { Beta }-1 \\
\text { Gamma }-0 \\
\text { Delta }-26\end{array}$ & 68 & $\begin{array}{l}\text { Alpha }-41,1 \\
\text { Beta }-1,4 \\
\text { Gamma }-0 \\
\text { Delta }-38,2\end{array}$ \\
\hline $\begin{array}{c}\text { Индия } \\
\text { (снижение заболеваемо- } \\
\text { сти) }\end{array}$ & $\begin{array}{l}\text { Department of Neurovirology, Na- } \\
\text { tional Institute of Mental Health } \\
\text { and Neurosciences (NIMHANS). } \\
\text { CSIR-Centre for Cellular and Mo- } \\
\text { lecular Biology }\end{array}$ & $\begin{array}{l}\text { Alpha }-3074 \\
\text { Beta }-194 \\
\text { Gamma }-2 \\
\text { Delta }-6656\end{array}$ & $\begin{array}{c}281 \\
50\end{array}$ & $\begin{array}{l}\text { Alpha }-11,0 \\
\text { Beta }-0,7 \\
\text { Gamma }-0,0 \\
\text { Delta }-23,5\end{array}$ & $\begin{array}{l}\text { Alpha }-0 \\
\text { Beta }-0 \\
\text { Gamma }-0 \\
\text { Delta }-39\end{array}$ & 203 & $\begin{array}{l}\text { Alpha }-0 \\
\text { Beta }-0 \\
\text { Gamma }-0 \\
\text { Delta }-19,2\end{array}$ \\
\hline
\end{tabular}




\begin{tabular}{|c|c|c|c|c|c|c|c|}
\hline $\begin{array}{c}\text { Индонезия } \\
\text { (рост } \\
\text { заболеваемости) }\end{array}$ & $\begin{array}{l}\text { National Institute of Health Re- } \\
\text { search and Development }\end{array}$ & $\begin{array}{l}\text { Alpha }-49 \\
\text { Beta }-6 \\
\text { Gamma }-0 \\
\text { Delta }-246\end{array}$ & $\begin{array}{c}230 \\
5\end{array}$ & $\begin{array}{l}\text { Alpha }-2,1 \\
\text { Beta }-0,2 \\
\text { Gamma }-0 \\
\text { Delta }-10,6\end{array}$ & $\begin{array}{l}\text { Alpha }-7 \\
\text { Beta }-2 \\
\text { Gamma }-0 \\
\text { Delta }-168\end{array}$ & 250 & $\begin{array}{l}\text { Alpha }-2,8 \\
\text { Beta }-0,8 \\
\text { Gamma }-0 \\
\text { Delta }-67,2\end{array}$ \\
\hline $\begin{array}{c}\text { Иордания } \\
\text { (стабилизация } \\
\text { заболеваемости) }\end{array}$ & $\begin{array}{l}\text { Andersen lab at Scripps Research, } \\
\text { CA, USA }\end{array}$ & $\begin{array}{l}\text { Alpha }-67 \\
\text { Beta }-2 \\
\text { Gamma }-5 \\
\text { Delta }-1\end{array}$ & 654 & $\begin{array}{l}\text { Alpha }-10,2 \\
\text { Beta }-0,3 \\
\text { Gamma }-0,8 \\
\text { Delta }-0,1\end{array}$ & $\begin{array}{l}\text { Alpha }-0 \\
\text { Beta }-0 \\
\text { Gamma }-0 \\
\text { Delta }-0\end{array}$ & 0 & $\begin{array}{l}\text { Alpha }-0 \\
\text { Beta }-0 \\
\text { Gamma }-0 \\
\text { Delta }-0\end{array}$ \\
\hline $\begin{array}{c}\text { Ирак } \\
\text { (рост заболеваемости) }\end{array}$ & $\begin{array}{l}\text { Biology, College of Education } \\
\text { Department of Virology, Faculty of } \\
\text { Medicine, University of Helsinki, } \\
\text { Helsinki, Finland generated and } \\
\text { submitted to GISAID }\end{array}$ & $\begin{array}{l}\text { Alpha }-64 \\
\text { Beta }-1 \\
\text { Gamma }-0 \\
\text { Delta }-0\end{array}$ & 191 & $\begin{array}{l}\text { Alpha }-33,5 \\
\text { Beta }-0,5 \\
\text { Gamma }-0 \\
\text { Delta }-0\end{array}$ & $\begin{array}{l}\text { Alpha }-0 \\
\text { Beta }-0 \\
\text { Gamma }-0 \\
\text { Delta }-0\end{array}$ & 0 & $\begin{array}{l}\text { Alpha }-0 \\
\text { Beta }-0 \\
\text { Gamma }-0 \\
\text { Delta }-0\end{array}$ \\
\hline $\begin{array}{c}\text { Иран } \\
\text { (стабилизация } \\
\text { заболеваемости) }\end{array}$ & $\begin{array}{l}\text { National Reference Laboratory for } \\
\text { COVID-19, Pasteur Institute of } \\
\text { Iran }\end{array}$ & $\begin{array}{l}\text { Alpha }-45 \\
\text { Beta }-2 \\
\text { Gamma }-0 \\
\text { Delta }-11\end{array}$ & 373 & $\begin{array}{l}\text { Alpha }-12,0 \\
\text { Beta }-0,5 \\
\text { Gamma }-0 \\
\text { Delta }-3\end{array}$ & $\begin{array}{l}\text { Alpha }-0 \\
\text { Beta }-0 \\
\text { Gamma }-0 \\
\text { Delta }-0\end{array}$ & 0 & $\begin{array}{l}\text { Alpha }-0 \\
\text { Beta }-0 \\
\text { Gamma }-0 \\
\text { Delta }-0\end{array}$ \\
\hline $\begin{array}{c}\text { Ирландия } \\
\text { (снижение заболеваемо- } \\
\text { сти) }\end{array}$ & $\begin{array}{l}\text { National Virus Reference Labora- } \\
\text { tory }\end{array}$ & $\begin{array}{l}\text { Alpha }- \\
13126 \\
\text { Beta }-69 \\
\text { Gamma }-27 \\
\text { Delta }-205 \\
\end{array}$ & $\begin{array}{c}168 \\
30\end{array}$ & $\begin{array}{l}\text { Alpha }-78 \\
\text { Beta }-0,4 \\
\text { Gamma }-0,1 \\
\text { Delta }-1,2\end{array}$ & $\begin{array}{l}\text { Alpha }-274 \\
\text { Beta }-0 \\
\text { Gamma }-1 \\
\text { Delta }-33\end{array}$ & 681 & $\begin{array}{l}\text { Alpha }-40,2 \\
\text { Beta }-0 \\
\text { Gamma }-0,1 \\
\text { Delta }-4,8\end{array}$ \\
\hline $\begin{array}{c}\text { Исландия } \\
\text { (стабилизация } \\
\text { заболеваемости) }\end{array}$ & deCODE genetics & $\begin{array}{l}\text { Alpha }-20 \\
\text { Beta }-0 \\
\text { Gamma }-0 \\
\text { Delta }-0\end{array}$ & $\begin{array}{c}507 \\
0\end{array}$ & $\begin{array}{l}\text { Alpha }-0,4 \\
\text { Beta }-0 \\
\text { Gamma }-0 \\
\text { Delta }-0\end{array}$ & $\begin{array}{l}\text { Alpha }-0 \\
\text { Beta }-0 \\
\text { Gamma }-0 \\
\text { Delta }-0\end{array}$ & 0 & $\begin{array}{l}\text { Alpha }-0 \\
\text { Beta }-0 \\
\text { Gamma }-0 \\
\text { Delta }-0\end{array}$ \\
\hline $\begin{array}{c}\text { Испания } \\
\text { (снижение заболеваемо- } \\
\text { сти) }\end{array}$ & $\begin{array}{l}\text { Hospital Universitario } 12 \text { de Oc- } \\
\text { tubre }\end{array}$ & $\begin{array}{l}\text { Alpha }- \\
15519 \\
\text { Beta }-260 \\
\text { Gamma }-673 \\
\text { Delta }-474 \\
\end{array}$ & $\begin{array}{c}350 \\
70\end{array}$ & $\begin{array}{l}\text { Alpha }-44,2 \\
\text { Beta }-0,7 \\
\text { Gamma }-2 \\
\text { Delta }-1,3\end{array}$ & $\begin{array}{l}\text { Alpha }-925 \\
\text { Beta }-14 \\
\text { Gamma }-55 \\
\text { Delta }-256\end{array}$ & 1811 & $\begin{array}{l}\text { Alpha }-51,0 \\
\text { Beta }-0,8 \\
\text { Gamma }-3,0 \\
\text { Delta }-14,1\end{array}$ \\
\hline
\end{tabular}




\begin{tabular}{|c|c|c|c|c|c|c|c|}
\hline $\begin{array}{c}\text { Италия } \\
\text { (снижение заболеваемо- } \\
\text { сти) }\end{array}$ & $\begin{array}{l}\text { Army Medical Center, Scientific } \\
\text { Department, Virology Laboratory }\end{array}$ & $\begin{array}{l}\text { Alpha - } \\
21648 \\
\text { Beta }-45 \\
\text { Gamma }-464 \\
\text { Delta }-390\end{array}$ & $\begin{array}{c}329 \\
70\end{array}$ & $\begin{array}{l}\text { Alpha }-65,6 \\
\text { Beta }-0,1 \\
\text { Gamma }-1,4 \\
\text { Delta }-1,1\end{array}$ & $\begin{array}{l}\text { Alpha }-638 \\
\text { Beta }-1 \\
\text { Gamma }-55 \\
\text { Delta }-188\end{array}$ & 1275 & $\begin{array}{l}\text { Alpha }-50,0 \\
\text { Beta }-0 \\
\text { Gamma }-4,3 \\
\text { Delta }-14,7\end{array}$ \\
\hline $\begin{array}{c}\text { Казахстан } \\
\text { (стабилизация } \\
\text { заболеваемости) }\end{array}$ & $\begin{array}{l}\text { Reference laboratory for the control } \\
\text { of viral infections }\end{array}$ & $\begin{array}{l}\text { Alpha }-160 \\
\text { Beta }-0 \\
\text { Gamma }-0 \\
\text { Delta }-0\end{array}$ & 334 & $\begin{array}{l}\text { Alpha }-48 \\
\text { Beta }-0 \\
\text { Gamma }-0 \\
\text { Delta }-0\end{array}$ & $\begin{array}{l}\text { Alpha }-0 \\
\text { Beta }-0 \\
\text { Gamma }-0 \\
\text { Delta }-0\end{array}$ & 0 & $\begin{array}{l}\text { Alpha }-0 \\
\text { Beta }-0 \\
\text { Gamma }-0 \\
\text { Delta }-0\end{array}$ \\
\hline $\begin{array}{c}\text { Камбоджи } \\
\text { (стабилизация } \\
\text { заболеваемости) }\end{array}$ & $\begin{array}{l}\text { Virology Unit, Institut Pasteur du } \\
\text { Cambodge }\end{array}$ & $\begin{array}{l}\text { Alpha }-293 \\
\text { Beta }-1 \\
\text { Gamma }-0 \\
\text { Delta }-13\end{array}$ & 372 & $\begin{array}{l}\text { Alpha }-78,7 \\
\text { Beta }-0,2 \\
\text { Gamma }-0 \\
\text { Delta }-3,5\end{array}$ & $\begin{array}{l}\text { Alpha }-61 \\
\text { Beta }-1 \\
\text { Gamma }-0 \\
\text { Delta }-12\end{array}$ & 89 & $\begin{array}{l}\text { Alpha }-68,5 \\
\text { Beta }-1,1 \\
\text { Gamma }-0 \\
\text { Delta }-13,4\end{array}$ \\
\hline $\begin{array}{c}\text { Камерун } \\
\text { (стабилизация заболевае- } \\
\text { мости) }\end{array}$ & $\begin{array}{l}\text { CREMER(Centre de Recher- } \\
\text { cherches sur les Maladies Emer- } \\
\text { gentes et Ré-émergentes) }\end{array}$ & $\begin{array}{l}\text { Alpha }-14 \\
\text { Beta }-9 \\
\text { Gamma }-0 \\
\text { Delta }-0\end{array}$ & 204 & $\begin{array}{l}\text { Alpha }-6,8 \\
\text { Beta }-4,4 \\
\text { Gamma }-0 \\
\text { Delta }-0\end{array}$ & $\begin{array}{l}\text { Alpha }-0 \\
\text { Beta }-0 \\
\text { Gamma }-0 \\
\text { Delta }-0\end{array}$ & 0 & $\begin{array}{l}\text { Alpha }-0 \\
\text { Beta }-0 \\
\text { Gamma }-0 \\
\text { Delta }-0\end{array}$ \\
\hline $\begin{array}{c}\text { Канада } \\
\text { (снижение заболеваемо- } \\
\text { сти) }\end{array}$ & $\begin{array}{l}\text { Laboratoire de santé publique du } \\
\text { Québec }\end{array}$ & $\begin{array}{l}\text { Alpha - } \\
16755 \\
\text { Beta }-751 \\
\text { Gamma }- \\
4748 \\
\text { Delta }-743\end{array}$ & $\begin{array}{c}455 \\
60\end{array}$ & $\begin{array}{l}\text { Alpha }-36,7 \\
\text { Beta }-1,6 \\
\text { Gamma }-10,4 \\
\text { Delta }-1,6\end{array}$ & $\begin{array}{l}\text { Alpha }-0 \\
\text { Beta }-0 \\
\text { Gamma }-0 \\
\text { Delta }-0\end{array}$ & 0 & $\begin{array}{l}\text { Alpha }-0 \\
\text { Beta }-0 \\
\text { Gamma }-0 \\
\text { Delta }-0\end{array}$ \\
\hline $\begin{array}{c}\text { Катар } \\
\text { (снижение заболеваемо- } \\
\text { сти) }\end{array}$ & $\begin{array}{l}\text { Biomedical Research Center } \\
\text { (BRC), Qatar University / Qatar } \\
\text { Genome Project (QGP) }\end{array}$ & $\begin{array}{l}\text { Alpha }-200 \\
\text { Beta }-468 \\
\text { Gamma }-0 \\
\text { Delta }-29\end{array}$ & $\begin{array}{c}245 \\
2\end{array}$ & $\begin{array}{l}\text { Alpha }-8,1 \\
\text { Beta }-19,0 \\
\text { Gamma }-0 \\
\text { Delta }-1,1\end{array}$ & $\begin{array}{l}\text { Alpha }-0 \\
\text { Beta }-0 \\
\text { Gamma }-0 \\
\text { Delta }-0\end{array}$ & 0 & $\begin{array}{l}\text { Alpha }-0 \\
\text { Beta }-0 \\
\text { Gamma }-0 \\
\text { Delta }-0\end{array}$ \\
\hline $\begin{array}{c}\text { Каймановы Острова } \\
\text { (снижение заболеваемо- } \\
\text { сти) }\end{array}$ & $\begin{array}{l}\text { Carrington Lab, Department of } \\
\text { PreClinical Sciences, Building 36, } \\
\text { First Floor Biochemistry Unit, Fac- } \\
\text { ulty of Medical Sciences, The Uni- } \\
\text { versity of the West Indies }\end{array}$ & $\begin{array}{l}\text { Alpha }-5 \\
\text { Beta }-0 \\
\text { Gamma }-0 \\
\text { Delta }-0\end{array}$ & 9 & $\begin{array}{l}\text { Alpha }-55,6 \\
\text { Beta }-0 \\
\text { Gamma }-0 \\
\text { Delta }-0\end{array}$ & $\begin{array}{l}\text { Alpha }-0 \\
\text { Beta }-0 \\
\text { Gamma }-0 \\
\text { Delta }-0\end{array}$ & 2 & $\begin{array}{l}\text { Alpha }-0 \\
\text { Beta }-0 \\
\text { Gamma }-0 \\
\text { Delta }-0\end{array}$ \\
\hline
\end{tabular}




\begin{tabular}{|c|c|c|c|c|c|c|c|}
\hline $\begin{array}{c}\text { Кения } \\
\text { (рост заболеваемости) }\end{array}$ & $\begin{array}{l}\text { KEMRI-Wellcome Trust Research } \\
\text { Programme/KEMRI-CGMR-C } \\
\text { Kilifi }\end{array}$ & $\begin{array}{l}\text { Alpha }-375 \\
\text { Beta }-166 \\
\text { Gamma }-0 \\
\text { Delta }-37\end{array}$ & $\begin{array}{c}146 \\
8\end{array}$ & $\begin{array}{l}\text { Alpha }-25,5 \\
\text { Beta }-11,3 \\
\text { Gamma }-0 \\
\text { Delta }-2,5\end{array}$ & $\begin{array}{l}\text { Alpha }-9 \\
\text { Beta }-2 \\
\text { Gamma }-0 \\
\text { Delta }-4\end{array}$ & 22 & $\begin{array}{l}\text { Alpha }-41 \\
\text { Beta }-9,1 \\
\text { Gamma }-0 \\
\text { Delta }-18,1\end{array}$ \\
\hline $\begin{array}{c}\text { Кипр } \\
\text { (рост заболеваемости) }\end{array}$ & $\begin{array}{l}\text { Department of Molecular Virology, } \\
\text { Cyprus Institute of Neurology and } \\
\text { Genetics }\end{array}$ & $\begin{array}{l}\text { Alpha }-10 \\
\text { Beta }-0 \\
\text { Gamma }-0 \\
\text { Delta }-0\end{array}$ & 133 & $\begin{array}{l}\text { Alpha }-7,5 \\
\text { Beta }-0 \\
\text { Gamma }-0 \\
\text { Delta }-0\end{array}$ & $\begin{array}{l}\text { Alpha }-0 \\
\text { Beta }-0 \\
\text { Gamma }-0 \\
\text { Delta }-0\end{array}$ & 0 & $\begin{array}{l}\text { Alpha }-0 \\
\text { Beta }-0 \\
\text { Gamma }-0 \\
\text { Delta }-0\end{array}$ \\
\hline $\begin{array}{c}\text { Китай } \\
\text { (стабилизация заболевае- } \\
\text { мости) }\end{array}$ & $\begin{array}{l}\text { National Institute for Viral Disease } \\
\text { Control and Prevention }\end{array}$ & $\begin{array}{l}\text { Alpha }-92 \\
\text { Beta }-85 \\
\text { Gamma }-2 \\
\text { Delta }-14\end{array}$ & $\begin{array}{c}309 \\
7\end{array}$ & $\begin{array}{l}\text { Alpha }-2,9 \\
\text { Beta }-2,7 \\
\text { Gamma }-0 \\
\text { Delta }-0,4\end{array}$ & $\begin{array}{l}\text { Alpha }-9 \\
\text { Beta }-0 \\
\text { Gamma }-0 \\
\text { Delta }-0\end{array}$ & 31 & $\begin{array}{l}\text { Alpha }-29 \\
\text { Beta }-0 \\
\text { Gamma }-0 \\
\text { Delta }-0\end{array}$ \\
\hline $\begin{array}{c}\text { Колумбия } \\
\text { (стабилизация } \\
\text { заболеваемости) }\end{array}$ & $\begin{array}{l}\text { Instituto Nacional de Salud- Direc- } \\
\text { ción de Investigación en Salud Pú- } \\
\text { blica }\end{array}$ & $\begin{array}{l}\text { Alpha }-84 \\
\text { Beta }-1 \\
\text { Gamma }-275 \\
\text { Delta }-0\end{array}$ & $\begin{array}{c}169 \\
2\end{array}$ & $\begin{array}{l}\text { Alpha }-4,9 \\
\text { Beta }-0 \\
\text { Gamma }-16,2 \\
\text { Delta }-0\end{array}$ & $\begin{array}{l}\text { Alpha }-0 \\
\text { Beta }-0 \\
\text { Gamma }-0 \\
\text { Delta }-0\end{array}$ & 13 & $\begin{array}{l}\text { Alpha }-0 \\
\text { Beta }-0 \\
\text { Gamma }-0 \\
\text { Delta }-0\end{array}$ \\
\hline $\begin{array}{c}\text { Косово } \\
\text { (стабилизация } \\
\text { заболеваемости) }\end{array}$ & $\begin{array}{l}\text { Charité Universitätsmedizin Berlin, } \\
\text { Institut für Virologie }\end{array}$ & $\begin{array}{l}\text { Alpha }-3 \\
\text { Beta }-0 \\
\text { Gamma }-0 \\
\text { Delta }-0\end{array}$ & 30 & $\begin{array}{l}\text { Alpha }-10,0 \\
\text { Beta }-0 \\
\text { Gamma }-0 \\
\text { Delta }-0\end{array}$ & $\begin{array}{l}\text { Alpha }-0 \\
\text { Beta }-0 \\
\text { Gamma }-0 \\
\text { Delta }-0\end{array}$ & 0 & $\begin{array}{l}\text { Alpha }-0 \\
\text { Beta }-0 \\
\text { Gamma }-0 \\
\text { Delta }-0\end{array}$ \\
\hline $\begin{array}{c}\text { Коста-Рика } \\
\text { (снижение заболеваемо- } \\
\text { сти) }\end{array}$ & $\begin{array}{l}\text { Inciensa, Instituto Costarricense de } \\
\text { Investigación y Enseñanza en Nu- } \\
\text { trición y Salud }\end{array}$ & $\begin{array}{l}\text { Alpha }-78 \\
\text { Beta }-11 \\
\text { Gamma }-30 \\
\text { Delta }-0\end{array}$ & 641 & $\begin{array}{l}\text { Alpha }-12,1 \\
\text { Beta }-1,7 \\
\text { Gamma }-4,6 \\
\text { Delta }-0\end{array}$ & $\begin{array}{l}\text { Alpha }-0 \\
\text { Beta }-0 \\
\text { Gamma }-0 \\
\text { Delta }-0\end{array}$ & 0 & $\begin{array}{l}\text { Alpha }-0 \\
\text { Beta }-0 \\
\text { Gamma }-0 \\
\text { Delta }-0\end{array}$ \\
\hline $\begin{array}{c}\text { Кот Д'Ивуар } \\
\text { (стабилизация заболевае- } \\
\text { мости) }\end{array}$ & $\begin{array}{l}\text { Molecular diagnostic unit for viral } \\
\text { haemorrhagic fevers and emerging } \\
\text { viruses, Bouaké CHU Laboratory }\end{array}$ & $\begin{array}{l}\text { Alpha }-15 \\
\text { Beta }-1 \\
\text { Gamma }-0 \\
\text { Delta }-0\end{array}$ & 145 & $\begin{array}{l}\text { Alpha }-10,3 \\
\text { Beta }-0,7 \\
\text { Gamma }-0 \\
\text { Delta }-0\end{array}$ & $\begin{array}{l}\text { Alpha }-0 \\
\text { Beta }-0 \\
\text { Gamma }-0 \\
\text { Delta }-0\end{array}$ & 0 & $\begin{array}{l}\text { Alpha }-0 \\
\text { Beta }-0 \\
\text { Gamma }-0 \\
\text { Delta }-0\end{array}$ \\
\hline $\begin{array}{c}\text { Кувейт } \\
\text { (рост заболеваемости) }\end{array}$ & $\begin{array}{l}\text { Virology Unit, Department of Mi- } \\
\text { crobiology, Faculty of Medicine, } \\
\text { Kuwait }\end{array}$ & $\begin{array}{l}\text { Alpha }-21 \\
\text { Beta }-0 \\
\text { Gamma }-0 \\
\text { Delta }-1\end{array}$ & 58 & $\begin{array}{l}\text { Alpha }-36,2 \\
\text { Beta }-0 \\
\text { Gamma }-0 \\
\text { Delta }-1,7\end{array}$ & $\begin{array}{l}\text { Alpha }-10 \\
\text { Beta }-0 \\
\text { Gamma }-0 \\
\text { Delta }-1\end{array}$ & 16 & $\begin{array}{l}\text { Alpha }-62,5 \\
\text { Beta }-0 \\
\text { Gamma }-0 \\
\text { Delta }-6,2\end{array}$ \\
\hline
\end{tabular}




\begin{tabular}{|c|c|c|c|c|c|c|c|}
\hline $\begin{array}{c}\text { Кюрасао } \\
\text { (стабилизация заболевае- } \\
\text { мости) }\end{array}$ & $\begin{array}{l}\text { National Institute for Public Health } \\
\text { and the Environment (RIVM) }\end{array}$ & $\begin{array}{l}\text { Alpha }-308 \\
\text { Beta }-0 \\
\text { Gamma }-5 \\
\text { Delta }-1\end{array}$ & 423 & $\begin{array}{l}\text { Alpha }-72,8 \\
\text { Beta }-0 \\
\text { Gamma }-1,1 \\
\text { Delta }-0,2\end{array}$ & $\begin{array}{l}\text { Alpha }-0 \\
\text { Beta }-0 \\
\text { Gamma }-1 \\
\text { Delta }-0\end{array}$ & 1 & $\begin{array}{l}\text { Alpha }-0 \\
\text { Beta }-0 \\
\text { Gamma }-100 \\
\text { Delta }-0\end{array}$ \\
\hline $\begin{array}{c}\text { Латвия } \\
\text { (снижение заболеваемо- } \\
\text { сти) }\end{array}$ & $\begin{array}{l}\text { Latvian Biomedical Research and } \\
\text { Study Centre }\end{array}$ & $\begin{array}{l}\text { Alpha }-1205 \\
\text { Beta }-7 \\
\text { Gamma }-0 \\
\text { Delta }-0\end{array}$ & $\begin{array}{c}335 \\
0\end{array}$ & $\begin{array}{l}\text { Alpha }-35,9 \\
\text { Beta }-0,2 \\
\text { Gamma }-0 \\
\text { Delta }-0\end{array}$ & $\begin{array}{l}\text { Alpha }-0 \\
\text { Beta }-0 \\
\text { Gamma }-0 \\
\text { Delta }-0\end{array}$ & 0 & $\begin{array}{l}\text { Alpha }-0 \\
\text { Beta }-0 \\
\text { Gamma }-0 \\
\text { Delta }-0\end{array}$ \\
\hline $\begin{array}{c}\text { Лесото } \\
\text { (рост заболеваемости) }\end{array}$ & $\begin{array}{l}\text { National Institute for Communica- } \\
\text { ble Diseases of the National Health } \\
\text { Laboratory Service }\end{array}$ & $\begin{array}{l}\text { Alpha }-0 \\
\text { Beta }-14 \\
\text { Gamma }-0 \\
\text { Delta }-0\end{array}$ & 18 & $\begin{array}{l}\text { Alpha }-0 \\
\text { Beta }-77,8 \\
\text { Gamma }-0 \\
\text { Delta }-0\end{array}$ & $\begin{array}{l}\text { Alpha }-0 \\
\text { Beta }-0 \\
\text { Gamma }-0 \\
\text { Delta }-0\end{array}$ & 0 & $\begin{array}{l}\text { Alpha }-0 \\
\text { Beta }-0 \\
\text { Gamma }-0 \\
\text { Delta }-0\end{array}$ \\
\hline $\begin{array}{c}\text { Ливан } \\
\text { (снижение заболеваемо- } \\
\text { сти) }\end{array}$ & $\begin{array}{l}\text { Laboratory of Molecular Biology } \\
\text { and Cancer Immunology,Lebanese } \\
\text { University Public Health England }\end{array}$ & $\begin{array}{l}\text { Alpha }-16 \\
\text { Beta }-0 \\
\text { Gamma }-0 \\
\text { Delta }-0\end{array}$ & 65 & $\begin{array}{l}\text { Alpha }-24,6 \\
\text { Beta }-0 \\
\text { Gamma }-0 \\
\text { Delta }-0\end{array}$ & $\begin{array}{l}\text { Alpha }-0 \\
\text { Beta }-0 \\
\text { Gamma }-0 \\
\text { Delta }-0\end{array}$ & 0 & $\begin{array}{l}\text { Alpha }-0 \\
\text { Beta }-0 \\
\text { Gamma }-0 \\
\text { Delta }-0\end{array}$ \\
\hline $\begin{array}{c}\text { Литва } \\
\text { (снижение заболеваемо- } \\
\text { сти) }\end{array}$ & $\begin{array}{l}\text { Vilnius University Hospital San- } \\
\text { taros Klinikos, Center of Laborato- } \\
\text { ry Medicine }\end{array}$ & $\begin{array}{l}\text { Alpha }-8510 \\
\text { Beta }-11 \\
\text { Gamma }-3 \\
\text { Delta }-4\end{array}$ & $\begin{array}{c}126 \\
80\end{array}$ & $\begin{array}{l}\text { Alpha }-67,1 \\
\text { Beta }-0,1 \\
\text { Gamma }-0,0 \\
\text { Delta }-0\end{array}$ & $\begin{array}{l}\text { Alpha }-278 \\
\text { Beta }-0 \\
\text { Gamma }-1 \\
\text { Delta }-3\end{array}$ & 604 & $\begin{array}{l}\text { Alpha }-46,0 \\
\text { Beta }-0 \\
\text { Gamma }-0,1 \\
\text { Delta }-0,5\end{array}$ \\
\hline $\begin{array}{c}\text { Лихтенштейн } \\
\text { (снижение заболеваемо- } \\
\text { сти) }\end{array}$ & $\begin{array}{l}\text { Bergthaler laboratory, CeMM Re- } \\
\text { search Center for Molecular Medi- } \\
\text { cine of the Austrian Academy of } \\
\text { Sciences }\end{array}$ & $\begin{array}{l}\text { Alpha }-7 \\
\text { Beta }-0 \\
\text { Gamma }-0 \\
\text { Delta }-0\end{array}$ & 46 & $\begin{array}{l}\text { Alpha }-15,2 \\
\text { Beta }-0 \\
\text { Gamma }-0 \\
\text { Delta }-0\end{array}$ & $\begin{array}{l}\text { Alpha }-0 \\
\text { Beta }-0 \\
\text { Gamma }-0 \\
\text { Delta }-0\end{array}$ & 0 & $\begin{array}{l}\text { Alpha }-0 \\
\text { Beta }-0 \\
\text { Gamma }-0 \\
\text { Delta }-0\end{array}$ \\
\hline $\begin{array}{c}\text { Люксембург } \\
\text { (снижение заболеваемо- } \\
\text { сти) }\end{array}$ & $\begin{array}{l}\text { Laboratoire national de santé, Mi- } \\
\text { crobiology, Microbial Genomics } \\
\text { Platform }\end{array}$ & $\begin{array}{l}\text { Alpha }-3975 \\
\text { Beta }-745 \\
\text { Gamma }-47 \\
\text { Delta }-52\end{array}$ & $\begin{array}{c}913 \\
3\end{array}$ & $\begin{array}{l}\text { Alpha }-43,5 \\
\text { Beta }-8,1 \\
\text { Gamma }-0,5 \\
\text { Delta }-0,6\end{array}$ & $\begin{array}{l}\text { Alpha }-0 \\
\text { Beta }-0 \\
\text { Gamma }-0 \\
\text { Delta }-0\end{array}$ & 5 & $\begin{array}{l}\text { Alpha }-0 \\
\text { Beta }-0 \\
\text { Gamma }-0 \\
\text { Delta }-0\end{array}$ \\
\hline $\begin{array}{c}\text { Марокко } \\
\text { (стабилизация заболевае- } \\
\text { мости) }\end{array}$ & Laboratoire de Biotechnologie & $\begin{array}{l}\text { Alpha }-100 \\
\text { Beta }-0 \\
\text { Gamma }-0 \\
\text { Delta }-1\end{array}$ & 214 & $\begin{array}{l}\text { Alpha }-46,7 \\
\text { Beta }-0 \\
\text { Gamma - } 0 \\
\text { Delta }-0,5\end{array}$ & $\begin{array}{l}\text { Alpha }-0 \\
\text { Beta }-0 \\
\text { Gamma }-0 \\
\text { Delta }-0\end{array}$ & 0 & $\begin{array}{l}\text { Alpha }-0 \\
\text { Beta }-0 \\
\text { Gamma }-0 \\
\text { Delta }-0\end{array}$ \\
\hline
\end{tabular}




\begin{tabular}{|c|c|c|c|c|c|c|c|}
\hline Майотта & $\begin{array}{l}\text { National Reference Center for Vi- } \\
\text { ruses of Respiratory Infections, In- } \\
\text { stitut Pasteur, Paris }\end{array}$ & $\begin{array}{l}\text { Alpha }-2 \\
\text { Beta }-33 \\
\text { Gamma }-0 \\
\text { Delta }-0\end{array}$ & 705 & $\begin{array}{l}\text { Alpha }-0,2 \\
\text { Beta }-4,7 \\
\text { Gamma }-0 \\
\text { Delta }-0\end{array}$ & $\begin{array}{l}\text { Alpha }-0 \\
\text { Beta }-0 \\
\text { Gamma }-0 \\
\text { Delta }-0\end{array}$ & 0 & $\begin{array}{l}\text { Alpha }-0 \\
\text { Beta }-0 \\
\text { Gamma }-0 \\
\text { Delta }-0\end{array}$ \\
\hline $\begin{array}{c}\text { Малайзия } \\
\text { (снижение заболеваемо- } \\
\text { сти) }\end{array}$ & $\begin{array}{l}\text { Institute for Medical Research, In- } \\
\text { fectious Disease Research Centre, } \\
\text { National Institutes of Health, Min- } \\
\text { istry of Health Malaysia }\end{array}$ & $\begin{array}{l}\text { Alpha }-9 \\
\text { Beta }-109 \\
\text { Gamma }-0 \\
\text { Delta }-21\end{array}$ & $\begin{array}{c}130 \\
3\end{array}$ & $\begin{array}{l}\text { Alpha }-0,7 \\
\text { Beta }-8,3 \\
\text { Gamma }-0 \\
\text { Delta }-1,6\end{array}$ & $\begin{array}{l}\text { Alpha }-0 \\
\text { Beta }-6 \\
\text { Gamma }-0 \\
\text { Delta }-1\end{array}$ & 16 & $\begin{array}{l}\text { Alpha }-0 \\
\text { Beta }-37,5 \\
\text { Gamma }-0 \\
\text { Delta }-6,2\end{array}$ \\
\hline $\begin{array}{c}\text { Малави } \\
\text { (стабилизация заболевае- } \\
\text { мости) }\end{array}$ & $\begin{array}{l}\text { KRISP, KZN Research Innovation } \\
\text { and Sequencing Platform }\end{array}$ & $\begin{array}{l}\text { Alpha }-2 \\
\text { Beta }-292 \\
\text { Gamma }-0 \\
\text { Delta }-14\end{array}$ & 336 & $\begin{array}{l}\text { Alpha }-0,6 \\
\text { Beta }-87 \\
\text { Gamma }-0 \\
\text { Delta }-4,1\end{array}$ & $\begin{array}{l}\text { Alpha }-0 \\
\text { Beta }-0 \\
\text { Gamma }-0 \\
\text { Delta }-0\end{array}$ & 0 & $\begin{array}{l}\text { Alpha }-0 \\
\text { Beta }-0 \\
\text { Gamma }-0 \\
\text { Delta }-0\end{array}$ \\
\hline $\begin{array}{c}\text { Мальта } \\
\text { (стабилизация } \\
\text { заболеваемости) }\end{array}$ & $\begin{array}{l}\text { Molecular Diagnostics Pathology } \\
\text { Department Mater Dei Hospital } \\
\text { Malta }\end{array}$ & $\begin{array}{l}\text { Alpha }-140 \\
\text { Beta }-2 \\
\text { Gamma }-23 \\
\text { Delta }-1\end{array}$ & 175 & $\begin{array}{l}\text { Alpha }-80 \\
\text { Beta }-1,1 \\
\text { Gamma }-13,1 \\
\text { Delta }-0,6\end{array}$ & $\begin{array}{l}\text { Alpha }-0 \\
\text { Beta }-0 \\
\text { Gamma }-1 \\
\text { Delta }-0\end{array}$ & 5 & $\begin{array}{l}\text { Alpha }-0 \\
\text { Beta }-0 \\
\text { Gamma }-20 \\
\text { Delta }-0\end{array}$ \\
\hline $\begin{array}{c}\text { Мартиника } \\
\text { (снижение заболеваемо- } \\
\text { сти) }\end{array}$ & $\begin{array}{l}\text { CNR Virus des Infections Res- } \\
\text { piratoires - France SUD }\end{array}$ & $\begin{array}{l}\text { Alpha }-22 \\
\text { Beta }-2 \\
\text { Gamma }-0 \\
\text { Delta }-0\end{array}$ & 38 & $\begin{array}{l}\text { Alpha }-57,9 \\
\text { Beta }-5,2 \\
\text { Gamma }-0 \\
\text { Delta }-0\end{array}$ & $\begin{array}{l}\text { Alpha }-0 \\
\text { Beta }-0 \\
\text { Gamma }-0 \\
\text { Delta }-0\end{array}$ & 8 & $\begin{array}{l}\text { Alpha }-0 \\
\text { Beta }-0 \\
\text { Gamma }-0 \\
\text { Delta }-0 \\
\end{array}$ \\
\hline $\begin{array}{c}\text { Мексика } \\
\text { (стабилизация } \\
\text { заболеваемости) }\end{array}$ & $\begin{array}{l}\text { Instituto de diagnóstico y Referen- } \\
\text { ciaEpidemiologicos (INDRE) }\end{array}$ & $\begin{array}{l}\text { Alpha }-855 \\
\text { Beta }-19 \\
\text { Gamma }-529 \\
\text { Delta }-95\end{array}$ & $\begin{array}{c}117 \\
80\end{array}$ & $\begin{array}{l}\text { Alpha }-7,2 \\
\text { Beta }-0,1 \\
\text { Gamma }-4,5 \\
\text { Delta }-0,8\end{array}$ & $\begin{array}{l}\text { Alpha -99 } \\
\text { Beta - 0 } \\
\text { Gamma - } \\
133 \\
\text { Delta - } 49\end{array}$ & 522 & $\begin{array}{l}\text { Alpha }-19 \\
\text { Beta }-0 \\
\text { Gamma }-25,4 \\
\text { Delta }-9,3\end{array}$ \\
\hline $\begin{array}{c}\text { Мозамбик } \\
\text { (стабилизация заболевае- } \\
\text { мости) }\end{array}$ & $\begin{array}{l}\text { KRISP, KZN Research Innovation } \\
\text { and Sequencing Platform, South } \\
\text { Africa }\end{array}$ & $\begin{array}{l}\text { Alpha }-0 \\
\text { Beta }-317 \\
\text { Gamma }-0 \\
\text { Delta }-0 \\
\end{array}$ & 475 & $\begin{array}{l}\text { Alpha }-0 \\
\text { Beta }-66,7 \\
\text { Gamma }-0 \\
\text { Delta }-0\end{array}$ & $\begin{array}{l}\text { Alpha }-0 \\
\text { Beta }-0 \\
\text { Gamma }-0 \\
\text { Delta }-0 \\
\end{array}$ & 0 & $\begin{array}{l}\text { Alpha }-0 \\
\text { Beta }-0 \\
\text { Gamma }-0 \\
\text { Delta }-0 \\
\end{array}$ \\
\hline $\begin{array}{c}\text { Маври́кий } \\
\text { (снижение заболеваемо- } \\
\text { сти) }\end{array}$ & $\begin{array}{l}\text { CNR Virus des Infections Res- } \\
\text { piratoires - France SUD }\end{array}$ & $\begin{array}{l}\text { Alpha }-1 \\
\text { Beta }-8 \\
\text { Gamma }-0 \\
\text { Delta }-2\end{array}$ & 164 & $\begin{array}{l}\text { Alpha }-0,6 \\
\text { Beta }-4,8 \\
\text { Gamma }-0 \\
\text { Delta }-1,2\end{array}$ & $\begin{array}{l}\text { Alpha -0 } \\
\text { Beta - 0 } \\
\text { Gamma - } 0 \\
\text { Delta -0 }\end{array}$ & 0 & $\begin{array}{l}\text { Alpha -0 } \\
\text { Beta - 0 } \\
\text { Gamma -0 } \\
\text { Delta -0 }\end{array}$ \\
\hline
\end{tabular}




\begin{tabular}{|c|c|c|c|c|c|c|c|}
\hline $\begin{array}{c}\text { Молдавия } \\
\text { (стабилизация } \\
\text { заболеваемости) }\end{array}$ & ONCOGENE LLC & $\begin{array}{l}\text { Alpha }-3 \\
\text { Beta }-0 \\
\text { Gamma }-0 \\
\text { Delta }-0\end{array}$ & 12 & $\begin{array}{l}\text { Alpha }-25,0 \\
\text { Beta }-0 \\
\text { Gamma }-0 \\
\text { Delta }-0\end{array}$ & $\begin{array}{l}\text { Alpha }-0 \\
\text { Beta }-0 \\
\text { Gamma }-0 \\
\text { Delta }-0\end{array}$ & 0 & $\begin{array}{l}\text { Alpha }-0 \\
\text { Beta }-0 \\
\text { Gamma }-0 \\
\text { Delta }-0\end{array}$ \\
\hline $\begin{array}{c}\text { Монако } \\
\text { (рост заболеваемости) }\end{array}$ & $\begin{array}{l}\text { National Reference Center for Vi- } \\
\text { ruses of Respiratory Infections, In- } \\
\text { stitut Pasteur, Paris }\end{array}$ & $\begin{array}{l}\text { Alpha }-3 \\
\text { Beta }-0 \\
\text { Gamma }-0 \\
\text { Delta }-0 \\
\end{array}$ & 8 & $\begin{array}{l}\text { Alpha }-37,5 \\
\text { Beta }-0 \\
\text { Gamma }-0 \\
\text { Delta }-0\end{array}$ & $\begin{array}{l}\text { Alpha }-0 \\
\text { Beta }-0 \\
\text { Gamma }-0 \\
\text { Delta }-0\end{array}$ & 0 & $\begin{array}{l}\text { Alpha }-0 \\
\text { Beta }-0 \\
\text { Gamma }-0 \\
\text { Delta }-0\end{array}$ \\
\hline $\begin{array}{c}\text { Монголия } \\
\text { (рост заболеваемости) }\end{array}$ & $\begin{array}{l}\text { National Center for Communicable } \\
\text { Diseases (NCCD) National Influ- } \\
\text { enza Center }\end{array}$ & $\begin{array}{l}\text { Alpha }-3 \\
\text { Beta }-0 \\
\text { Gamma }-0 \\
\text { Delta }-0\end{array}$ & 27 & $\begin{array}{l}\text { Alpha }-37,5 \\
\text { Beta }-0 \\
\text { Gamma }-0 \\
\text { Delta }-0\end{array}$ & $\begin{array}{l}\text { Alpha }-0 \\
\text { Beta }-0 \\
\text { Gamma }-0 \\
\text { Delta }-0\end{array}$ & 0 & $\begin{array}{l}\text { Alpha }-0 \\
\text { Beta }-0 \\
\text { Gamma }-0 \\
\text { Delta }-0\end{array}$ \\
\hline $\begin{array}{c}\text { Монтсеррат } \\
\text { (стабилизация } \\
\text { заболеваемости) }\end{array}$ & $\begin{array}{l}\text { Carrington Lab, Department of } \\
\text { Preclinical Sciences, Faculty of } \\
\text { Medical Sciences, The University } \\
\text { of the West Indies }\end{array}$ & $\begin{array}{l}\text { Alpha }-2 \\
\text { Beta }-0 \\
\text { Gamma }-0 \\
\text { Delta }-0\end{array}$ & 2 & $\begin{array}{l}\text { Alpha }-100 \\
\text { Beta }-0 \\
\text { Gamma }-0 \\
\text { Delta }-0\end{array}$ & $\begin{array}{l}\text { Alpha }-0 \\
\text { Beta }-0 \\
\text { Gamma }-0 \\
\text { Delta }-0\end{array}$ & 2 & $\begin{array}{l}\text { Alpha }-0 \\
\text { Beta }-0 \\
\text { Gamma }-0 \\
\text { Delta }-0\end{array}$ \\
\hline $\begin{array}{c}\text { Мьянма } \\
\text { (стабилизация } \\
\text { заболеваемости) }\end{array}$ & DSMRC & $\begin{array}{l}\text { Alpha }-2 \\
\text { Beta }-0 \\
\text { Gamma }-0 \\
\text { Delta }-4\end{array}$ & 20 & $\begin{array}{l}\text { Alpha }-10 \\
\text { Beta }-0 \\
\text { Gamma }-0 \\
\text { Delta }-20\end{array}$ & $\begin{array}{l}\text { Alpha }-2 \\
\text { Beta }-0 \\
\text { Gamma }-0 \\
\text { Delta }-4\end{array}$ & 10 & $\begin{array}{l}\text { Alpha }-20 \\
\text { Beta }-0 \\
\text { Gamma }-0 \\
\text { Delta }-40\end{array}$ \\
\hline $\begin{array}{c}\text { Намибия } \\
\text { (рост заболеваемости) }\end{array}$ & $\begin{array}{l}\text { National Institute for Communica- } \\
\text { ble Diseases of the National Health } \\
\text { Laboratory Service }\end{array}$ & $\begin{array}{l}\text { Alpha }-0 \\
\text { Beta }-9 \\
\text { Gamma }-0 \\
\text { Delta }-0\end{array}$ & 57 & $\begin{array}{l}\text { Alpha }-0 \\
\text { Beta }-15,8 \\
\text { Gamma }-0 \\
\text { Delta }-0\end{array}$ & $\begin{array}{l}\text { Alpha }-0 \\
\text { Beta }-0 \\
\text { Gamma }-0 \\
\text { Delta }-0\end{array}$ & 0 & $\begin{array}{l}\text { Alpha }-0 \\
\text { Beta }-0 \\
\text { Gamma }-0 \\
\text { Delta }-0\end{array}$ \\
\hline $\begin{array}{c}\text { Непал } \\
\text { (снижение заболеваемо- } \\
\text { сти) }\end{array}$ & $\begin{array}{l}\text { Molecular and Genomics Research } \\
\text { Lab, Dhulikhel Hospital, Kathman- } \\
\text { du University Hospital } \\
\text { School of Public Health, The Uni- } \\
\text { versity of Hong Kong }\end{array}$ & $\begin{array}{l}\text { Alpha }-10 \\
\text { Beta }-0 \\
\text { Gamma }-0 \\
\text { Delta }-38\end{array}$ & 64 & $\begin{array}{l}\text { Alpha }-15,6 \\
\text { Beta }-0 \\
\text { Gamma }-0 \\
\text { Delta }-59,3\end{array}$ & $\begin{array}{l}\text { Alpha }-0 \\
\text { Beta }-0 \\
\text { Gamma }-0 \\
\text { Delta }-0\end{array}$ & 0 & $\begin{array}{l}\text { Alpha }-0 \\
\text { Beta }-0 \\
\text { Gamma }-0 \\
\text { Delta }-0\end{array}$ \\
\hline
\end{tabular}




\begin{tabular}{|c|c|c|c|c|c|c|c|}
\hline $\begin{array}{c}\text { Нигерия } \\
\text { (стабилизация заболевае- } \\
\text { мости) }\end{array}$ & $\begin{array}{l}\text { African Centre of Excellence for } \\
\text { Genomics of Infectious Diseases } \\
\text { (ACEGID), Redeemer's University }\end{array}$ & $\begin{array}{l}\text { Alpha }-140 \\
\text { Beta }-1 \\
\text { Gamma }-0 \\
\text { Delta }-0\end{array}$ & 827 & $\begin{array}{l}\text { Alpha }-17 \\
\text { Beta }-0,1 \\
\text { Gamma }-0 \\
\text { Delta }-0\end{array}$ & $\begin{array}{l}\text { Alpha }-0 \\
\text { Beta }-0 \\
\text { Gamma }-0 \\
\text { Delta }-0\end{array}$ & 0 & $\begin{array}{l}\text { Alpha }-0 \\
\text { Beta }-0 \\
\text { Gamma }-0 \\
\text { Delta }-0\end{array}$ \\
\hline $\begin{array}{c}\text { Нидерланды } \\
\text { (снижение заболеваемо- } \\
\text { сти) }\end{array}$ & $\begin{array}{l}\text { National Institute for Public Health } \\
\text { and the Environment (RIVM) }\end{array}$ & $\begin{array}{l}\text { Alpha - } \\
25366 \\
\text { Beta - } 687 \\
\text { Gamma - } 487 \\
\text { Delta - } 132\end{array}$ & $\begin{array}{c}390 \\
10\end{array}$ & $\begin{array}{l}\text { Alpha }-65,0 \\
\text { Beta }-1,8 \\
\text { Gamma }-1,2 \\
\text { Delta }-0,3\end{array}$ & $\begin{array}{l}\text { Alpha - } \\
1041 \\
\text { Beta - } 2 \\
\text { Gamma - 34 } \\
\text { Delta - 41 }\end{array}$ & 1558 & $\begin{array}{l}\text { Alpha }-66,8 \\
\text { Beta }-0,1 \\
\text { Gamma }-2,1 \\
\text { Delta }-2,6\end{array}$ \\
\hline $\begin{array}{c}\text { Новая Зеландия } \\
\text { (стабилизация заболевае- } \\
\text { мости) }\end{array}$ & $\begin{array}{l}\text { Institute of Environmental Science } \\
\text { and Research (ESR) }\end{array}$ & $\begin{array}{l}\text { Alpha }-146 \\
\text { Beta }-27 \\
\text { Gamma }-6 \\
\text { Delta }-13\end{array}$ & $\begin{array}{c}108 \\
6\end{array}$ & $\begin{array}{l}\text { Alpha }-13,4 \\
\text { Beta }-2,5 \\
\text { Gamma }-0,6 \\
\text { Delta }-1,2\end{array}$ & $\begin{array}{l}\text { Alpha }-0 \\
\text { Beta }-0 \\
\text { Gamma }-0 \\
\text { Delta }-0\end{array}$ & 11 & $\begin{array}{l}\text { Alpha }-0 \\
\text { Beta }-0 \\
\text { Gamma }-0 \\
\text { Delta }-0\end{array}$ \\
\hline $\begin{array}{c}\text { Норвегия } \\
\text { (снижение заболеваемо- } \\
\text { сти) }\end{array}$ & $\begin{array}{l}\text { Norwegian Institute of Public } \\
\text { Health, Department of Virology }\end{array}$ & $\begin{array}{l}\text { Alpha }-7241 \\
\text { Beta }-353 \\
\text { Gamma }-6 \\
\text { Delta }-89 \\
\end{array}$ & $\begin{array}{c}120 \\
30\end{array}$ & $\begin{array}{l}\text { Alpha }-60,2 \\
\text { Beta }-3,0 \\
\text { Gamma }-0,0 \\
\text { Delta }-0,7\end{array}$ & $\begin{array}{l}\text { Alpha }-404 \\
\text { Beta }-1 \\
\text { Gamma }-2 \\
\text { Delta }-18 \\
\end{array}$ & 566 & $\begin{array}{l}\text { Alpha }-71,3 \\
\text { Beta }-0,1 \\
\text { Gamma }-0,3 \\
\text { Delta }-3,1\end{array}$ \\
\hline $\begin{array}{c}\text { ОАЭ } \\
\text { (стабилизация } \\
\text { заболеваемости) }\end{array}$ & $\begin{array}{l}\text { Wellcome Sanger Institute for the } \\
\text { COVID-19 Genomics UK (COG- } \\
\text { UK) Consortium }\end{array}$ & $\begin{array}{l}\text { Alpha }-21 \\
\text { Beta }-5 \\
\text { Gamma }-0 \\
\text { Delta }-0 \\
\end{array}$ & $\begin{array}{c}184 \\
7\end{array}$ & $\begin{array}{l}\text { Alpha }-1,1 \\
\text { Beta }-0,3 \\
\text { Gamma }-0 \\
\text { Delta }-0\end{array}$ & $\begin{array}{l}\text { Alpha }-0 \\
\text { Beta }-0 \\
\text { Gamma }-0 \\
\text { Delta }-0 \\
\end{array}$ & 0 & $\begin{array}{l}\text { Alpha }-0 \\
\text { Beta }-0 \\
\text { Gamma }-0 \\
\text { Delta }-0 \\
\end{array}$ \\
\hline $\begin{array}{c}\text { Оман } \\
\text { (рост заболеваемости) }\end{array}$ & Oman-National Influenza Center & $\begin{array}{l}\text { Alpha }-1 \\
\text { Beta }-0 \\
\text { Gamma }-0 \\
\text { Delta }-0 \\
\end{array}$ & 249 & $\begin{array}{l}\text { Alpha }-0,4 \\
\text { Beta }-0 \\
\text { Gamma }-0 \\
\text { Delta }-0\end{array}$ & $\begin{array}{l}\text { Alpha }-0 \\
\text { Beta }-0 \\
\text { Gamma }-0 \\
\text { Delta }-0 \\
\end{array}$ & 0 & $\begin{array}{l}\text { Alpha }-0 \\
\text { Beta }-0 \\
\text { Gamma }-0 \\
\text { Delta }-0 \\
\end{array}$ \\
\hline $\begin{array}{c}\text { Пакистан } \\
\text { (стабилизация } \\
\text { заболеваемости) }\end{array}$ & $\begin{array}{l}\text { Department of Virology, Public } \\
\text { Health Laboratories Division }\end{array}$ & $\begin{array}{l}\text { Alpha }-175 \\
\text { Beta }-17 \\
\text { Gamma }-0 \\
\text { Delta }-9 \\
\end{array}$ & 414 & $\begin{array}{l}\text { Alpha }-42,2 \\
\text { Beta }-4,1 \\
\text { Gamma }-0 \\
\text { Delta }-2,1\end{array}$ & $\begin{array}{l}\text { Alpha }-1 \\
\text { Beta }-0 \\
\text { Gamma }-0 \\
\text { Delta }-1 \\
\end{array}$ & 8 & $\begin{array}{l}\text { Alpha }-12,5 \\
\text { Beta }-0 \\
\text { Gamma }-0 \\
\text { Delta }-12,5\end{array}$ \\
\hline $\begin{array}{c}\text { Палестина } \\
\text { (снижение заболеваемо- } \\
\text { сти) }\end{array}$ & $\begin{array}{l}\text { Biochemistry and Molecular Biol- } \\
\text { ogy Department-Faculty of Medi- } \\
\text { cine, Al-Quds University }\end{array}$ & $\begin{array}{l}\text { Alpha }-27 \\
\text { Beta }-0 \\
\text { Gamma }-0 \\
\text { Delta }-0\end{array}$ & 132 & $\begin{array}{l}\text { Alpha }-20,4 \\
\text { Beta }-0 \\
\text { Gamma }-0 \\
\text { Delta }-0\end{array}$ & $\begin{array}{l}\text { Alpha }-0 \\
\text { Beta }-0 \\
\text { Gamma }-0 \\
\text { Delta }-0\end{array}$ & 0 & $\begin{array}{l}\text { Alpha }-0 \\
\text { Beta }-0 \\
\text { Gamma }-0 \\
\text { Delta }-0\end{array}$ \\
\hline
\end{tabular}




\begin{tabular}{|c|c|c|c|c|c|c|c|}
\hline $\begin{array}{c}\text { Панама } \\
\text { (рост заболеваемости) }\end{array}$ & $\begin{array}{l}\text { Gorgas memorial Institute For } \\
\text { Health Studies }\end{array}$ & $\begin{array}{l}\text { Alpha }-0 \\
\text { Beta }-2 \\
\text { Gamma }-0 \\
\text { Delta }-0\end{array}$ & 896 & $\begin{array}{l}\text { Alpha }-0 \\
\text { Beta }-0,2 \\
\text { Gamma }-0 \\
\text { Delta }-0\end{array}$ & $\begin{array}{l}\text { Alpha }-0 \\
\text { Beta }-0 \\
\text { Gamma }-0 \\
\text { Delta }-0\end{array}$ & 0 & $\begin{array}{l}\text { Alpha }-0 \\
\text { Beta }-0 \\
\text { Gamma }-0 \\
\text { Delta }-0\end{array}$ \\
\hline $\begin{array}{c}\text { Парагвай } \\
\text { (снижение заболеваемо- } \\
\text { сти) }\end{array}$ & $\begin{array}{l}\text { Laboratorio Central de Salud Pub- } \\
\text { lica de Paraguay }\end{array}$ & $\begin{array}{l}\text { Alpha }-4 \\
\text { Beta }-0 \\
\text { Gamma }-53 \\
\text { Delta }-0\end{array}$ & 159 & $\begin{array}{l}\text { Alpha }-2,5 \\
\text { Beta }-0 \\
\text { Gamma }-33,3 \\
\text { Delta }-0\end{array}$ & $\begin{array}{l}\text { Alpha }-0 \\
\text { Beta }-0 \\
\text { Gamma }-0 \\
\text { Delta }-0\end{array}$ & 0 & $\begin{array}{l}\text { Alpha }-0 \\
\text { Beta }-0 \\
\text { Gamma }-0 \\
\text { Delta }-0\end{array}$ \\
\hline $\begin{array}{c}\text { Перу } \\
\text { (снижение заболеваемо- } \\
\text { сти) }\end{array}$ & $\begin{array}{l}\text { Laboratorio de Referencia Nacional } \\
\text { de Biotecnología y Biología Mo- } \\
\text { lecular. Instituto Nacional de } \\
\text { SaludPerú }\end{array}$ & $\begin{array}{l}\text { Alpha }-8 \\
\text { Beta }-0 \\
\text { Gamma }-25 \\
\text { Delta }-2\end{array}$ & $\begin{array}{c}143 \\
3\end{array}$ & $\begin{array}{l}\text { Alpha }-0,6 \\
\text { Beta }-0 \\
\text { Gamma }-1,7 \\
\text { Delta }-0,1\end{array}$ & $\begin{array}{l}\text { Alpha }-0 \\
\text { Beta }-0 \\
\text { Gamma }-0 \\
\text { Delta }-1\end{array}$ & 3 & $\begin{array}{l}\text { Alpha }-0 \\
\text { Beta }-0 \\
\text { Gamma }-0 \\
\text { Delta }-33,3\end{array}$ \\
\hline $\begin{array}{c}\text { Польша } \\
\text { (стабилизация } \\
\text { заболеваемости) }\end{array}$ & $\begin{array}{l}\text { genXone SA, Research \& Devel- } \\
\text { opment Laboratory }\end{array}$ & $\begin{array}{l}\text { Alpha - } \\
14045 \\
\text { Beta - } 42 \\
\text { Gamma - } 5 \\
\text { Delta - } 80\end{array}$ & $\begin{array}{l}164 \\
20\end{array}$ & $\begin{array}{l}\text { Alpha }-85,5 \\
\text { Beta }-0,3 \\
\text { Gamma }-0,0 \\
\text { Delta }-0,4\end{array}$ & $\begin{array}{l}\text { Alpha }-305 \\
\text { Beta }-0 \\
\text { Gamma }-1 \\
\text { Delta }-6\end{array}$ & 709 & $\begin{array}{l}\text { Alpha }-43,0 \\
\text { Beta }-0 \\
\text { Gamma }-0,1 \\
\text { Delta }-0,8\end{array}$ \\
\hline $\begin{array}{c}\text { Португалия } \\
\text { (рост заболеваемости) }\end{array}$ & Instituto Nacional de Saude (INSA) & $\begin{array}{l}\text { Alpha }-4471 \\
\text { Beta }-96 \\
\text { Gamma }-159 \\
\text { Delta }-343 \\
\end{array}$ & $\begin{array}{c}925 \\
1\end{array}$ & $\begin{array}{l}\text { Alpha }-48,3 \\
\text { Beta }-1,0 \\
\text { Gamma }-1,7 \\
\text { Delta }-3,7 \\
\end{array}$ & $\begin{array}{l}\text { Alpha }-229 \\
\text { Beta }-1 \\
\text { Gamma }-15 \\
\text { Delta }-237\end{array}$ & 520 & $\begin{array}{l}\text { Alpha }-44,0 \\
\text { Beta }-1 \\
\text { Gamma }-2,8 \\
\text { Delta }-45,5\end{array}$ \\
\hline $\begin{array}{c}\text { Республика Джибути } \\
\text { (стабилизация } \\
\text { заболеваемости) }\end{array}$ & $\begin{array}{l}\text { Naval Medical Research Center } \\
\text { Biological Defense Research Di- } \\
\text { rectorate }\end{array}$ & $\begin{array}{l}\text { Alpha }-28 \\
\text { Beta }-18 \\
\text { Gamma }-0 \\
\text { Delta }-0\end{array}$ & 52 & $\begin{array}{l}\text { Alpha }-53,8 \\
\text { Beta }-34,6 \\
\text { Gamma }-0 \\
\text { Delta }-0\end{array}$ & $\begin{array}{l}\text { Alpha }-0 \\
\text { Beta }-0 \\
\text { Gamma }-0 \\
\text { Delta }-0\end{array}$ & 0 & $\begin{array}{l}\text { Alpha }-0 \\
\text { Beta }-0 \\
\text { Gamma }-0 \\
\text { Delta }-0\end{array}$ \\
\hline $\begin{array}{c}\text { Республика Конго } \\
\text { (стабилизация заболевае- } \\
\text { мости) }\end{array}$ & Institute of Tropical Medicine & $\begin{array}{l}\text { Alpha }-3 \\
\text { Beta }-0 \\
\text { Gamma }-0 \\
\text { Delta }-0\end{array}$ & 125 & $\begin{array}{l}\text { Alpha }-2,4 \\
\text { Beta }-0 \\
\text { Gamma }-0 \\
\text { Delta }-0\end{array}$ & $\begin{array}{l}\text { Alpha }-0 \\
\text { Beta }-0 \\
\text { Gamma }-0 \\
\text { Delta }-0\end{array}$ & 0 & $\begin{array}{l}\text { Alpha }-0 \\
\text { Beta }-0 \\
\text { Gamma }-0 \\
\text { Delta }-0\end{array}$ \\
\hline Реюньон & $\begin{array}{l}\text { CNR Virus des Infections Res- } \\
\text { piratoires - France SUD }\end{array}$ & $\begin{array}{l}\text { Alpha }-58 \\
\text { Beta }-307 \\
\text { Gamma }-0 \\
\text { Delta }-2\end{array}$ & $\begin{array}{c}124 \\
0\end{array}$ & $\begin{array}{l}\text { Alpha } 4,6 \\
\text { Beta }-24,7 \\
\text { Gamma }-0 \\
\text { Delta }-0,2 \\
\end{array}$ & $\begin{array}{l}\text { Alpha }-0 \\
\text { Beta }-16 \\
\text { Gamma }-0 \\
\text { Delta }-0\end{array}$ & 109 & $\begin{array}{l}\text { Alpha }-0 \\
\text { Beta }-14,6 \\
\text { Gamma }-0 \\
\text { Delta }-0 \\
\end{array}$ \\
\hline
\end{tabular}




\begin{tabular}{|c|c|c|c|c|c|c|c|}
\hline $\begin{array}{c}\text { Россия } \\
\text { (рост заболеваемости) }\end{array}$ & $\begin{array}{l}\text { WHO National Influenza Centre } \\
\text { Russian Federation. } \\
\text { Center for Precision Genome Edit- } \\
\text { ing and Genetic Technologies for } \\
\text { Biomedicine, Pirogov Medical } \\
\text { University, Moscow, Russian Fed- } \\
\text { eration. } \\
\text { Federal Budget Institution of Sci- } \\
\text { ence, State Research Center for } \\
\text { Applied Microbiology \& Biotech- } \\
\text { nology. } \\
\text { Group of Genetic Engeneering and } \\
\text { Biotechnology, Federal Budget In- } \\
\text { stitution of Science 'Central Re- } \\
\text { search Institute of Epidemiology' } \\
\text { of The Federal Service on Custom- } \\
\text { ers' Rights Protection and Human } \\
\text { Well-being Surveillance. } \\
\text { State Research Center of Virology } \\
\text { and Biotechnology VECTOR, De- } \\
\text { partment of Collection of Microor- } \\
\text { ganisms. }\end{array}$ & $\begin{array}{l}\text { Alpha }-306 \\
\text { Beta }-21 \\
\text { Gamma }-0 \\
\text { Delta }-311\end{array}$ & $\begin{array}{c}497 \\
7\end{array}$ & $\begin{array}{l}\text { Alpha }-6,1 \\
\text { Beta }-0,4 \\
\text { Gamma }-0 \\
\text { Delta }-6,2\end{array}$ & $\begin{array}{l}\text { Alpha }-2 \\
\text { Beta }-0 \\
\text { Gamma }-0 \\
\text { Delta }-89\end{array}$ & 137 & $\begin{array}{l}\text { Alpha }-1,5 \\
\text { Beta }-0 \\
\text { Gamma }-0 \\
\text { Delta }-65\end{array}$ \\
\hline $\begin{array}{c}\text { Румыния } \\
\text { (стабилизация } \\
\text { заболеваемости) }\end{array}$ & $\begin{array}{l}\text { National Institute of Infectious Dis- } \\
\text { eases-Prof. Dr. Matei Bals Molecu- } \\
\text { lar Diagnostics Laboratory }\end{array}$ & $\begin{array}{l}\text { Alpha }-542 \\
\text { Beta }-7 \\
\text { Gamma }-5 \\
\text { Delta }-22\end{array}$ & 996 & $\begin{array}{l}\text { Alpha }-54,4 \\
\text { Beta }-0,7 \\
\text { Gamma }-0,5 \\
\text { Delta }-2,2\end{array}$ & $\begin{array}{l}\text { Alpha }-13 \\
\text { Beta }-0 \\
\text { Gamma }-0 \\
\text { Delta }-2\end{array}$ & 69 & $\begin{array}{l}\text { Alpha }-18,8 \\
\text { Beta }-0 \\
\text { Gamma }-0 \\
\text { Delta }-2,9\end{array}$ \\
\hline $\begin{array}{c}\text { Руанда } \\
\text { (рост заболеваемости) }\end{array}$ & GIGA Medical Genomics & $\begin{array}{l}\text { Alpha }-7 \\
\text { Beta }-30 \\
\text { Gamma }-0 \\
\text { Delta }-0\end{array}$ & 343 & $\begin{array}{l}\text { Alpha }-2,0 \\
\text { Beta }-8,7 \\
\text { Gamma }-0 \\
\text { Delta }-0\end{array}$ & $\begin{array}{l}\text { Alpha }-0 \\
\text { Beta }-1 \\
\text { Gamma }-0 \\
\text { Delta }-0\end{array}$ & 1 & $\begin{array}{l}\text { Alpha }-0 \\
\text { Beta }-100 \\
\text { Gamma }-0 \\
\text { Delta }-0\end{array}$ \\
\hline $\begin{array}{c}\text { Саудовская Аравия } \\
\text { (стабилизация заболевае- } \\
\text { мости) }\end{array}$ & $\begin{array}{l}\text { Infectious Diseases, King Faisal } \\
\text { Hospital Research Center }\end{array}$ & $\begin{array}{l}\text { Alpha }-1 \\
\text { Beta }-1 \\
\text { Gamma }-0\end{array}$ & 957 & $\begin{array}{l}\text { Alpha }-0,1 \\
\text { Beta }-0,1 \\
\text { Gamma }-0\end{array}$ & $\begin{array}{l}\text { Alpha }-0 \\
\text { Beta }-0 \\
\text { Gamma }-0\end{array}$ & 0 & $\begin{array}{l}\text { Alpha }-0 \\
\text { Beta }-0 \\
\text { Gamma }-0\end{array}$ \\
\hline
\end{tabular}




\begin{tabular}{|c|c|c|c|c|c|c|c|}
\hline & & Delta -0 & & Delta -0 & Delta -0 & & Delta -0 \\
\hline $\begin{array}{c}\text { Северная Македония } \\
\text { (стабилизация } \\
\text { заболеваемости) }\end{array}$ & $\begin{array}{l}\text { Institute of Public Health of Repub- } \\
\text { lic of North Macedonia Laboratory } \\
\text { of Virology and Molecular Diag- } \\
\text { nostics }\end{array}$ & $\begin{array}{l}\text { Alpha }-187 \\
\text { Beta }-1 \\
\text { Gamma }-0 \\
\text { Delta }-0\end{array}$ & 534 & $\begin{array}{l}\text { Alpha }-35,0 \\
\text { Beta }-0,2 \\
\text { Gamma }-0 \\
\text { Delta }-0\end{array}$ & $\begin{array}{l}\text { Alpha }-0 \\
\text { Beta }-0 \\
\text { Gamma }-0 \\
\text { Delta }-0\end{array}$ & 0 & $\begin{array}{l}\text { Alpha }-0 \\
\text { Beta }-0 \\
\text { Gamma }-0 \\
\text { Delta }-0\end{array}$ \\
\hline $\begin{array}{c}\text { Сенегал } \\
\text { (стабилизация заболевае- } \\
\text { мости) }\end{array}$ & IRESSEF GENOMICS LAB & $\begin{array}{l}\text { Alpha }-20 \\
\text { Beta }-0 \\
\text { Gamma }-0 \\
\text { Delta }-2\end{array}$ & 422 & $\begin{array}{l}\text { Alpha }-4,7 \\
\text { Beta }-0 \\
\text { Gamma }-0 \\
\text { Delta }-0,4\end{array}$ & $\begin{array}{l}\text { Alpha }-0 \\
\text { Beta }-0 \\
\text { Gamma }-0 \\
\text { Delta }-0\end{array}$ & 0 & $\begin{array}{l}\text { Alpha }-0 \\
\text { Beta }-0 \\
\text { Gamma }-0 \\
\text { Delta }-0\end{array}$ \\
\hline $\begin{array}{c}\text { Сент-Люсия } \\
\text { (снижение заболеваемо- } \\
\text { сти) }\end{array}$ & $\begin{array}{l}\text { Carrington Lab, Department of } \\
\text { PreClinical Sciences }\end{array}$ & $\begin{array}{l}\text { Alpha }-20 \\
\text { Beta }-0 \\
\text { Gamma }-0 \\
\text { Delta }-0 \\
\end{array}$ & 25 & $\begin{array}{l}\text { Alpha }-80,0 \\
\text { Beta }-0 \\
\text { Gamma }-0 \\
\text { Delta }-0\end{array}$ & $\begin{array}{l}\text { Alpha }-0 \\
\text { Beta }-0 \\
\text { Gamma }-0 \\
\text { Delta }-0 \\
\end{array}$ & 0 & $\begin{array}{l}\text { Alpha }-0 \\
\text { Beta }-0 \\
\text { Gamma }-0 \\
\text { Delta }-0 \\
\end{array}$ \\
\hline $\begin{array}{c}\text { Сербия } \\
\text { (снижение заболеваемо- } \\
\text { сти) }\end{array}$ & $\begin{array}{l}\text { Institute of microbiology and Im- } \\
\text { munology, Faculty of Medicine, } \\
\text { University of Belgrade }\end{array}$ & $\begin{array}{l}\text { Alpha }-23 \\
\text { Beta }-0 \\
\text { Gamma }-0 \\
\text { Delta }-0\end{array}$ & 255 & $\begin{array}{l}\text { Alpha }-9,0 \\
\text { Beta }-0 \\
\text { Gamma }-0 \\
\text { Delta }-0\end{array}$ & $\begin{array}{l}\text { Alpha }-0 \\
\text { Beta }-0 \\
\text { Gamma }-0 \\
\text { Delta }-0\end{array}$ & 0 & $\begin{array}{l}\text { Alpha }-0 \\
\text { Beta }-0 \\
\text { Gamma }-0 \\
\text { Delta }-0\end{array}$ \\
\hline $\begin{array}{c}\text { Сингапур } \\
\text { (стабилизация заболевае- } \\
\text { мости) }\end{array}$ & $\begin{array}{l}\text { National Public Health Laboratory, } \\
\text { National Centre for Infectious Dis- } \\
\text { eases }\end{array}$ & $\begin{array}{l}\text { Alpha }-186 \\
\text { Beta }-95 \\
\text { Gamma }-8 \\
\text { Delta }-823\end{array}$ & $\begin{array}{c}321 \\
0\end{array}$ & $\begin{array}{l}\text { Alpha }-5,8 \\
\text { Beta }-3,0 \\
\text { Gamma }-0,2 \\
\text { Delta }-25,6\end{array}$ & $\begin{array}{l}\text { Alpha }-2 \\
\text { Beta }-7 \\
\text { Gamma }-2 \\
\text { Delta }-268\end{array}$ & 326 & $\begin{array}{l}\text { Alpha }-0,6 \\
\text { Beta }-2,1 \\
\text { Gamma }-0,6 \\
\text { Delta }-82,2\end{array}$ \\
\hline $\begin{array}{c}\text { Синт-Мартен } \\
\text { (снижение заболеваемо- } \\
\text { сти) }\end{array}$ & $\begin{array}{l}\text { National Institute for Public Health } \\
\text { and the Environment (RIVM) }\end{array}$ & $\begin{array}{l}\text { Alpha }-266 \\
\text { Beta }-1 \\
\text { Gamma }-0 \\
\text { Delta }-1\end{array}$ & 344 & $\begin{array}{l}\text { Alpha }-77,3 \\
\text { Beta }-0,3 \\
\text { Gamma }-0 \\
\text { Delta }-0,3\end{array}$ & $\begin{array}{l}\text { Alpha }-65 \\
\text { Beta }-0 \\
\text { Gamma }-0 \\
\text { Delta }-0\end{array}$ & 78 & $\begin{array}{l}\text { Alpha }-83,3 \\
\text { Beta }-0 \\
\text { Gamma }-0 \\
\text { Delta }-0\end{array}$ \\
\hline $\begin{array}{c}\text { Словакия } \\
\text { (снижение заболеваемо- } \\
\text { сти) }\end{array}$ & $\begin{array}{l}\text { Faculty of Natural Sciences, Co- } \\
\text { menius University }\end{array}$ & $\begin{array}{l}\text { Alpha }-3181 \\
\text { Beta }-27 \\
\text { Gamma }-0 \\
\text { Delta }-1\end{array}$ & $\begin{array}{c}367 \\
6\end{array}$ & $\begin{array}{l}\text { Alpha }-86,5 \\
\text { Beta }-0,7 \\
\text { Gamma }-0 \\
\text { Delta }-0,0\end{array}$ & $\begin{array}{l}\text { Alpha }-11 \\
\text { Beta }-0 \\
\text { Gamma }-0 \\
\text { Delta }-0\end{array}$ & 124 & $\begin{array}{l}\text { Alpha }-8,8 \\
\text { Beta }-0 \\
\text { Gamma }-0 \\
\text { Delta }-0\end{array}$ \\
\hline $\begin{array}{c}\text { Словения } \\
\text { (снижение заболеваемо- } \\
\text { сти) }\end{array}$ & $\begin{array}{l}\text { Institute of Microbiology and Im- } \\
\text { munology, Faculty of Medicine, } \\
\text { University of Ljubljana }\end{array}$ & $\begin{array}{l}\text { Alpha }-7023 \\
\text { Beta }-31 \\
\text { Gamma }-4 \\
\text { Delta }-6\end{array}$ & $\begin{array}{c}140 \\
40\end{array}$ & $\begin{array}{l}\text { Alpha - 50,7 } \\
\text { Beta - 0,2 } \\
\text { Gamma - 0,04 } \\
\text { Delta - 0,0 }\end{array}$ & $\begin{array}{l}\text { Alpha - } 106 \\
\text { Beta }-0 \\
\text { Gamma - } 1 \\
\text { Delta }-1\end{array}$ & 161 & $\begin{array}{l}\text { Alpha }-65,8 \\
\text { Beta }-0 \\
\text { Gamma }-0,6 \\
\text { Delta }-0,6\end{array}$ \\
\hline
\end{tabular}




\begin{tabular}{|c|c|c|c|c|c|c|c|}
\hline $\begin{array}{c}\text { Сомали } \\
\text { (стабилизация } \\
\text { заболеваемости) }\end{array}$ & $\begin{array}{l}\text { African Centre of Excellence for } \\
\text { Genomics of Infectious Diseases } \\
\text { (ACEGID), Redeemer's University }\end{array}$ & $\begin{array}{l}\text { Alpha }-2 \\
\text { Beta }-0 \\
\text { Gamma }-0 \\
\text { Delta }-0\end{array}$ & 26 & $\begin{array}{l}\text { Alpha }-7,7 \\
\text { Beta }-0 \\
\text { Gamma }-0 \\
\text { Delta }-0,0\end{array}$ & $\begin{array}{l}\text { Alpha }-0 \\
\text { Beta }-0 \\
\text { Gamma }-0 \\
\text { Delta }-0\end{array}$ & 0 & $\begin{array}{l}\text { Alpha }-0 \\
\text { Beta }-0 \\
\text { Gamma }-0 \\
\text { Delta }-0\end{array}$ \\
\hline $\begin{array}{c}\text { Суринам } \\
\text { (снижение заболеваемо- } \\
\text { сти) }\end{array}$ & $\begin{array}{l}\text { National Institute for Public Health } \\
\text { and the Environment (RIVM) }\end{array}$ & $\begin{array}{l}\text { Alpha }-15 \\
\text { Beta }-5 \\
\text { Gamma }-108 \\
\text { Delta }-0\end{array}$ & 338 & $\begin{array}{l}\text { Alpha }-4,4 \\
\text { Beta }-1,4 \\
\text { Gamma }-32,0 \\
\text { Delta }-0\end{array}$ & $\begin{array}{l}\text { Alpha }-0 \\
\text { Beta }-0 \\
\text { Gamma }-0 \\
\text { Delta }-0\end{array}$ & 1 & $\begin{array}{l}\text { Alpha }-0 \\
\text { Beta }-0 \\
\text { Gamma }-0 \\
\text { Delta }-0\end{array}$ \\
\hline $\begin{array}{c}\text { США } \\
\text { (снижение заболеваемо- } \\
\text { сти) }\end{array}$ & $\begin{array}{l}\text { Colorado Department of Public } \\
\text { Health \& Environment. } \\
\text { Maine Health and Environmental } \\
\text { Testing Laboratory. } \\
\text { California Department of Public } \\
\text { Health. UCSD EXCITE. }\end{array}$ & $\begin{array}{l}\text { Alpha - } \\
180784 \\
\text { Beta }-2122 \\
\text { Gamma - } \\
16187 \\
\text { Delta }-3476\end{array}$ & $\begin{array}{l}568 \\
073\end{array}$ & $\begin{array}{l}\text { Alpha }-31,8 \\
\text { Beta }-0,3 \\
\text { Gamma }-2,8 \\
\text { Delta }-0,6\end{array}$ & $\begin{array}{l}\text { Alpha - } \\
3659 \\
\text { Beta }-24 \\
\text { Gamma }- \\
874 \\
\text { Delta }-922\end{array}$ & 9153 & $\begin{array}{l}\text { Alpha }-40 \\
\text { Beta }-0,2 \\
\text { Gamma }-9,5 \\
\text { Delta }-10,0\end{array}$ \\
\hline $\begin{array}{c}\text { Таиланд } \\
\text { (стабилизация заболевае- } \\
\text { мости) }\end{array}$ & $\begin{array}{l}\text { COVID-19 Network Investigations } \\
\text { (CONI) Alliance }\end{array}$ & $\begin{array}{l}\text { Alpha }-663 \\
\text { Beta }-33 \\
\text { Gamma }-0 \\
\text { Delta }-94\end{array}$ & $\begin{array}{c}177 \\
8\end{array}$ & $\begin{array}{l}\text { Alpha }-37,2 \\
\text { Beta }-1,8 \\
\text { Gamma }-0 \\
\text { Delta }-5,2\end{array}$ & $\begin{array}{l}\text { Alpha }-5 \\
\text { Beta }-0 \\
\text { Gamma }-0 \\
\text { Delta }-6\end{array}$ & 39 & $\begin{array}{l}\text { Alpha }-12,8 \\
\text { Beta }-0 \\
\text { Gamma }-0 \\
\text { Delta }-15,3\end{array}$ \\
\hline $\begin{array}{c}\text { Тайвань } \\
\text { (снижение заболеваемо- } \\
\text { сти) }\end{array}$ & $\begin{array}{l}\text { Microbial Genomics Core Lab, Na- } \\
\text { tional Taiwan University Centers of } \\
\text { Genomic and Precision Medicine }\end{array}$ & $\begin{array}{l}\text { Alpha }-30 \\
\text { Beta }-0 \\
\text { Gamma }-4 \\
\text { Delta }-0\end{array}$ & 212 & $\begin{array}{l}\text { Alpha }-15 \\
\text { Beta }-0 \\
\text { Gamma }-1,8 \\
\text { Delta }-0\end{array}$ & $\begin{array}{l}\text { Alpha }-2 \\
\text { Beta }-0 \\
\text { Gamma }-0 \\
\text { Delta }-0\end{array}$ & 5 & $\begin{array}{l}\text { Alpha }-40 \\
\text { Beta }-0 \\
\text { Gamma }-0 \\
\text { Delta }-0\end{array}$ \\
\hline $\begin{array}{c}\text { Того } \\
\text { (стабилизация заболевае- } \\
\text { мости) }\end{array}$ & $\begin{array}{l}\text { Unité Mixte Internationale Trans- } \\
\text { VIHMI (UMI } 233 \text { IRD - U1175 } \\
\text { INSERM - Université de Montpel- } \\
\text { lier) IRD (Institut de recherche } \\
\text { pour le développement) }\end{array}$ & $\begin{array}{l}\text { Alpha }-21 \\
\text { Beta }-2 \\
\text { Gamma }-0 \\
\text { Delta }-0\end{array}$ & 125 & $\begin{array}{l}\text { Alpha }-16,8 \\
\text { Beta }-1,6 \\
\text { Gamma }-0 \\
\text { Delta }-0\end{array}$ & $\begin{array}{l}\text { Alpha }-0 \\
\text { Beta }-0 \\
\text { Gamma }-0 \\
\text { Delta }-0\end{array}$ & 0 & $\begin{array}{l}\text { Alpha }-0 \\
\text { Beta }-0 \\
\text { Gamma }-0 \\
\text { Delta }-0\end{array}$ \\
\hline $\begin{array}{c}\text { Тринидад и Тобаго } \\
\text { (снижение заболеваемо- } \\
\text { сти) }\end{array}$ & $\begin{array}{l}\text { Carrington Lab, Department of } \\
\text { PreClinical Sciences, Faculty of } \\
\text { Medical Sciences, The University } \\
\text { of the West Indies }\end{array}$ & $\begin{array}{l}\text { Alpha }-9 \\
\text { Beta }-0 \\
\text { Gamma }-63 \\
\text { Delta }-0\end{array}$ & 277 & $\begin{array}{l}\text { Alpha }-3,2 \\
\text { Beta }-0 \\
\text { Gamma }-22,7 \\
\text { Delta }-0\end{array}$ & $\begin{array}{l}\text { Alpha }-0 \\
\text { Beta }-0 \\
\text { Gamma }-0 \\
\text { Delta }-0\end{array}$ & 0 & $\begin{array}{l}\text { Alpha }-0 \\
\text { Beta }-0 \\
\text { Gamma }-0 \\
\text { Delta }-0\end{array}$ \\
\hline $\begin{array}{c}\text { Тунис } \\
\text { (рост заболеваемости) }\end{array}$ & $\begin{array}{l}\text { Laboratoire de 29linique 29linique } \\
\text { - Institut Pasteur de Tunis }\end{array}$ & $\begin{array}{l}\text { Alpha }-3 \\
\text { Beta }-1\end{array}$ & 116 & $\begin{array}{l}\text { Alpha }-2,6 \\
\text { Beta }-0,9\end{array}$ & $\begin{array}{l}\text { Alpha }-0 \\
\text { Beta }-0\end{array}$ & 0 & $\begin{array}{l}\text { Alpha }-0 \\
\text { Beta }-0\end{array}$ \\
\hline
\end{tabular}




\begin{tabular}{|c|c|c|c|c|c|c|c|}
\hline & & $\begin{array}{l}\text { Gamma }-0 \\
\text { Delta }-0\end{array}$ & & $\begin{array}{l}\text { Gamma }-0 \\
\text { Delta }-0\end{array}$ & $\begin{array}{l}\text { Gamma }-0 \\
\text { Delta }-0\end{array}$ & & $\begin{array}{l}\text { Gamma }-0 \\
\text { Delta }-0\end{array}$ \\
\hline $\begin{array}{c}\text { Турция } \\
\text { (стабилизация } \\
\text { заболеваемости) }\end{array}$ & Ministry of Health Turkey & $\begin{array}{l}\text { Alpha }-605 \\
\text { Beta }-539 \\
\text { Gamma }-23 \\
\text { Delta }-2 \\
\end{array}$ & $\begin{array}{c}523 \\
0\end{array}$ & $\begin{array}{l}\text { Alpha }-11,5 \\
\text { Beta }-10,4 \\
\text { Gamma }-0,4 \\
\text { Delta }-0,04\end{array}$ & $\begin{array}{l}\text { Alpha }-0 \\
\text { Beta }-0 \\
\text { Gamma }-0 \\
\text { Delta }-0 \\
\end{array}$ & 20 & $\begin{array}{l}\text { Alpha }-0 \\
\text { Beta }-0 \\
\text { Gamma }-0 \\
\text { Delta }-0 \\
\end{array}$ \\
\hline $\begin{array}{c}\text { Уганда } \\
\text { (рост заболеваемости) }\end{array}$ & $\begin{array}{l}\text { MRC/UVRI \& LSHTM Uganda } \\
\text { Research Unit }\end{array}$ & $\begin{array}{l}\text { Alpha }-11 \\
\text { Beta }-14 \\
\text { Gamma }-0 \\
\text { Delta }-4\end{array}$ & 428 & $\begin{array}{l}\text { Alpha }-2,6 \\
\text { Beta }-3,0 \\
\text { Gamma }-0 \\
\text { Delta }-1\end{array}$ & $\begin{array}{l}\text { Alpha }-0 \\
\text { Beta }-0 \\
\text { Gamma }-0 \\
\text { Delta }-0\end{array}$ & 0 & $\begin{array}{l}\text { Alpha }-0 \\
\text { Beta }-0 \\
\text { Gamma }-0 \\
\text { Delta }-0\end{array}$ \\
\hline $\begin{array}{c}\text { Украина } \\
\text { (снижение заболеваемо- } \\
\text { сти) }\end{array}$ & $\begin{array}{l}\text { Department of Respiratory and oth- } \\
\text { er Viral Infections of } \\
\text { L.V.Gromashevsky Institute of Ep- } \\
\text { idemiology \& Infectious Diseases } \\
\text { NAMS of Ukraine, JSC "Farmak" }\end{array}$ & $\begin{array}{l}\text { Alpha }-52 \\
\text { Beta }-0 \\
\text { Gamma }-0 \\
\text { Delta }-0\end{array}$ & 171 & $\begin{array}{l}\text { Alpha }-30,4 \\
\text { Beta }-0 \\
\text { Gamma }-0 \\
\text { Delta }-0\end{array}$ & $\begin{array}{l}\text { Alpha }-0 \\
\text { Beta }-0 \\
\text { Gamma }-0 \\
\text { Delta }-0\end{array}$ & 0 & $\begin{array}{l}\text { Alpha }-0 \\
\text { Beta }-0 \\
\text { Gamma }-0 \\
\text { Delta }-0\end{array}$ \\
\hline Уоллис и Футуна & $\begin{array}{l}\text { CNR Virus des Infections Res- } \\
\text { piratoires - France SUD }\end{array}$ & $\begin{array}{l}\text { Alpha }-10 \\
\text { Beta }-0 \\
\text { Gamma }-0 \\
\text { Delta }-0\end{array}$ & 10 & $\begin{array}{l}\text { Alpha }-100,0 \\
\text { Beta }-0 \\
\text { Gamma }-0 \\
\text { Delta }-0\end{array}$ & $\begin{array}{l}\text { Alpha }-0 \\
\text { Beta }-0 \\
\text { Gamma }-0 \\
\text { Delta }-0 \\
\end{array}$ & 10 & $\begin{array}{l}\text { Alpha }-0 \\
\text { Beta }-0 \\
\text { Gamma }-0 \\
\text { Delta }-0\end{array}$ \\
\hline $\begin{array}{c}\text { Уругвай } \\
\text { (снижение заболеваемо- } \\
\text { сти) }\end{array}$ & $\begin{array}{l}\text { Centro de Innovación en Vigilancia } \\
\text { Epidemiológica (CiVE), Institut } \\
\text { Pasteur Montevideo, Uruguay }\end{array}$ & $\begin{array}{l}\text { Alpha }-0 \\
\text { Beta }-0 \\
\text { Gamma }-171 \\
\text { Delta }-0\end{array}$ & 470 & $\begin{array}{l}\text { Alpha }-0 \\
\text { Beta }-0 \\
\text { Gamma }-36,3 \\
\text { Delta }-0\end{array}$ & $\begin{array}{l}\text { Alpha }-0 \\
\text { Beta }-0 \\
\text { Gamma }-0 \\
\text { Delta }-0 \\
\end{array}$ & 0 & $\begin{array}{l}\text { Alpha }-0 \\
\text { Beta }-0 \\
\text { Gamma }-0 \\
\text { Delta }-0\end{array}$ \\
\hline $\begin{array}{c}\text { Фарерские острова } \\
\text { (снижение заболеваемо- } \\
\text { сти) }\end{array}$ & $\begin{array}{l}\text { Faroese National Reference Labor- } \\
\text { atory for Fish and Animal Diseases }\end{array}$ & $\begin{array}{l}\text { Alpha }-2 \\
\text { Beta }-0 \\
\text { Gamma }-1 \\
\text { Delta }-0\end{array}$ & 42 & $\begin{array}{l}\text { Alpha }-4,8 \\
\text { Beta }-0 \\
\text { Gamma }-2,4 \\
\text { Delta }-0\end{array}$ & $\begin{array}{l}\text { Alpha }-0 \\
\text { Beta }-0 \\
\text { Gamma }-0 \\
\text { Delta }-0\end{array}$ & 0 & $\begin{array}{l}\text { Alpha }-0 \\
\text { Beta }-0 \\
\text { Gamma }-0 \\
\text { Delta }-0\end{array}$ \\
\hline $\begin{array}{c}\text { Филиппины } \\
\text { (стабилизация } \\
\text { заболеваемости) }\end{array}$ & Philippine Genome Center & $\begin{array}{l}\text { Alpha }-623 \\
\text { Beta }-693 \\
\text { Gamma }-1 \\
\text { Delta }-12 \\
\end{array}$ & $\begin{array}{c}430 \\
5\end{array}$ & $\begin{array}{l}\text { Alpha }-14,5 \\
\text { Beta }-16,1 \\
\text { Gamma }-0,0 \\
\text { Delta }-0,2\end{array}$ & $\begin{array}{l}\text { Alpha }-0 \\
\text { Beta }-0 \\
\text { Gamma }-0 \\
\text { Delta }-0 \\
\end{array}$ & 0 & $\begin{array}{l}\text { Alpha }-0 \\
\text { Beta }-0 \\
\text { Gamma }-0 \\
\text { Delta }-0\end{array}$ \\
\hline $\begin{array}{c}\text { Финляндия } \\
\text { (снижение заболеваемо- }\end{array}$ & $\begin{array}{l}\text { Department of Virology, Faculty of } \\
\text { Medicine, University of Helsinki }\end{array}$ & $\begin{array}{l}\text { Alpha }-5864 \\
\text { Beta }-1096\end{array}$ & $\begin{array}{c}114 \\
80 \\
\end{array}$ & $\begin{array}{l}\text { Alpha }-51,0 \\
\text { Beta }-9,5\end{array}$ & $\begin{array}{l}\text { Alpha }-0 \\
\text { Beta }-0\end{array}$ & 4 & $\begin{array}{l}\text { Alpha }-0 \\
\text { Beta }-0\end{array}$ \\
\hline
\end{tabular}




\begin{tabular}{|c|c|c|c|c|c|c|c|}
\hline сти) & & $\begin{array}{l}\text { Gamma }-2 \\
\text { Delta }-126\end{array}$ & & $\begin{array}{l}\text { Gamma }-0 \\
\text { Delta }-1,1\end{array}$ & $\begin{array}{l}\text { Gamma - } 0 \\
\text { Delta }-0\end{array}$ & & $\begin{array}{l}\text { Gamma }-0 \\
\text { Delta }-0\end{array}$ \\
\hline $\begin{array}{c}\text { Франция } \\
\text { (снижение заболеваемо- } \\
\text { сти) }\end{array}$ & $\begin{array}{l}\text { CNR Virus des Infections Res- } \\
\text { piratoires - France SUD }\end{array}$ & $\begin{array}{l}\text { Alpha - } \\
30616 \\
\text { Beta - } 1962 \\
\text { Gamma - 263 } \\
\text { Delta - 285 }\end{array}$ & $\begin{array}{c}455 \\
40\end{array}$ & $\begin{array}{l}\text { Alpha }-67,2 \\
\text { Beta }-4,3 \\
\text { Gamma }-0,6 \\
\text { Delta }-0,6\end{array}$ & $\begin{array}{l}\text { Alpha - } \\
1110 \\
\text { Beta - 93 } \\
\text { Gamma -9 } \\
\text { Delta - 128 } \\
\end{array}$ & 3302 & $\begin{array}{l}\text { Alpha }-33,6 \\
\text { Beta }-2,8 \\
\text { Gamma }-0,2 \\
\text { Delta }-3,9\end{array}$ \\
\hline Французская Гвиана & $\begin{array}{l}\text { National Reference Center for Vi- } \\
\text { ruses of Respiratory Infections, In- } \\
\text { stitut Pasteur, Paris }\end{array}$ & $\begin{array}{l}\text { Alpha }-43 \\
\text { Beta }-1 \\
\text { Gamma }-225 \\
\text { Delta }-0\end{array}$ & 433 & $\begin{array}{l}\text { Alpha }-10,0 \\
\text { Beta }-0,2 \\
\text { Gamma }-52,0 \\
\text { Delta }-0\end{array}$ & $\begin{array}{l}\text { Alpha }-0 \\
\text { Beta }-0 \\
\text { Gamma }-41 \\
\text { Delta }-0\end{array}$ & 45 & $\begin{array}{l}\text { Alpha }-0 \\
\text { Beta }-0 \\
\text { Gamma }-91,1 \\
\text { Delta }-0\end{array}$ \\
\hline $\begin{array}{c}\text { Хорватия } \\
\text { (снижение } \\
\text { заболеваемости) }\end{array}$ & Croatian Institute of Public Health & $\begin{array}{l}\text { Alpha }-2006 \\
\text { Beta }-15 \\
\text { Gamma }-0 \\
\text { Delta }-0\end{array}$ & $\begin{array}{c}312 \\
8\end{array}$ & $\begin{array}{l}\text { Alpha }-64,1 \\
\text { Beta }-0,4 \\
\text { Gamma }-0 \\
\text { Delta }-0 \\
\end{array}$ & $\begin{array}{l}\text { Alpha }-0 \\
\text { Beta }-0 \\
\text { Gamma }-0 \\
\text { Delta }-0 \\
\end{array}$ & 0 & $\begin{array}{l}\text { Alpha }-0 \\
\text { Beta }-0 \\
\text { Gamma }-0 \\
\text { Delta }-0 \\
\end{array}$ \\
\hline $\begin{array}{c}\text { Черногория } \\
\text { (снижение заболеваемо- } \\
\text { сти) }\end{array}$ & $\begin{array}{l}\text { Charité Universitätsmedizin Berlin, } \\
\text { Institut für Virologie }\end{array}$ & $\begin{array}{l}\text { Alpha }-7 \\
\text { Beta }-0 \\
\text { Gamma }-0 \\
\text { Delta }-0 \\
\end{array}$ & 31 & $\begin{array}{l}\text { Alpha }-22,6 \\
\text { Beta }-0 \\
\text { Gamma }-0 \\
\text { Delta }-0 \\
\end{array}$ & $\begin{array}{l}\text { Alpha }-0 \\
\text { Beta }-0 \\
\text { Gamma }-0 \\
\text { Delta }-0 \\
\end{array}$ & 0 & $\begin{array}{l}\text { Alpha }-0 \\
\text { Beta }-0 \\
\text { Gamma }-0 \\
\text { Delta }-0 \\
\end{array}$ \\
\hline $\begin{array}{c}\text { Чехия } \\
\text { (снижение заболеваемо- } \\
\text { сти) }\end{array}$ & $\begin{array}{l}\text { The National Institute of Public } \\
\text { Health }\end{array}$ & $\begin{array}{l}\text { Alpha }-3007 \\
\text { Beta }-60 \\
\text { Gamma }-8 \\
\text { Delta }-26 \\
\end{array}$ & $\begin{array}{c}443 \\
4\end{array}$ & $\begin{array}{l}\text { Alpha }-69,1 \\
\text { Beta }-1,3 \\
\text { Gamma }-0,1 \\
\text { Delta }-0,5\end{array}$ & $\begin{array}{l}\text { Alpha }-2 \\
\text { Beta }-1 \\
\text { Gamma }-0 \\
\text { Delta }-0\end{array}$ & 73 & $\begin{array}{l}\text { Alpha }-10 \\
\text { Beta }-1,3 \\
\text { Gamma }-0 \\
\text { Delta }-0\end{array}$ \\
\hline $\begin{array}{c}\text { Чили } \\
\text { (снижение заболеваемо- } \\
\text { сти) }\end{array}$ & Instituto de Salud Publica de Chile & $\begin{array}{l}\text { Alpha }-131 \\
\text { Beta }-3 \\
\text { Gamma }-859 \\
\text { Delta }-0\end{array}$ & $\begin{array}{c}357 \\
5\end{array}$ & $\begin{array}{l}\text { Alpha }-3,7 \\
\text { Beta }-0,09 \\
\text { Gamma }-24 \\
\text { Delta }-0\end{array}$ & $\begin{array}{l}\text { Alpha }-0 \\
\text { Beta }-0 \\
\text { Gamma }-3 \\
\text { Delta }-0\end{array}$ & 131 & $\begin{array}{l}\text { Alpha }-0 \\
\text { Beta }-0 \\
\text { Gamma }-2,3 \\
\text { Delta }-42,4\end{array}$ \\
\hline $\begin{array}{c}\text { Швейцария } \\
\text { (снижение заболеваемо- } \\
\text { сти) }\end{array}$ & $\begin{array}{l}\text { Department of Biosystems Science } \\
\text { and Engineering, ETH Zürich. }\end{array}$ & $\begin{array}{l}\text { Alpha - } \\
20998 \\
\text { Beta - } 214 \\
\text { Gamma - } 152 \\
\text { Delta - } 150\end{array}$ & $\begin{array}{c}447 \\
60\end{array}$ & $\begin{array}{l}\text { Alpha }-47 \\
\text { Beta }-0,4 \\
\text { Gamma }-0,3 \\
\text { Delta }-0,3\end{array}$ & $\begin{array}{l}\text { Alpha }-992 \\
\text { Beta }-10 \\
\text { Gamma }-15 \\
\text { Delta }-65\end{array}$ & 1500 & $\begin{array}{l}\text { Alpha }-66,1 \\
\text { Beta }-0,6 \\
\text { Gamma }-1 \\
\text { Delta }-4,3\end{array}$ \\
\hline Швеция & The Public Health Agency of Swe- & Alpha - & 685 & Alpha $-75,3$ & Alpha - 777 & 1076 & Alpha - 72,2 \\
\hline
\end{tabular}




\begin{tabular}{|c|c|c|c|c|c|c|c|}
\hline $\begin{array}{c}\text { (снижение заболеваемо- } \\
\text { сти) }\end{array}$ & den & $\begin{array}{l}51617 \\
\text { Beta }-2247 \\
\text { Gamma }-68 \\
\text { Delta }-167\end{array}$ & 50 & $\begin{array}{l}\text { Beta }-3,2 \\
\text { Gamma }-0,1 \\
\text { Delta }-0,2\end{array}$ & $\begin{array}{l}\text { Beta }-9 \\
\text { Gamma }-3 \\
\text { Delta }-110\end{array}$ & & $\begin{array}{l}\text { Beta }-0,8 \\
\text { Gamma }-0,2 \\
\text { Delta }-10,2\end{array}$ \\
\hline $\begin{array}{c}\text { Шри-Ланка } \\
\text { (снижение заболеваемо- } \\
\text { сти) }\end{array}$ & $\begin{array}{l}\text { Centre for Dengue Research and } \\
\text { AICBU, Department of Immunolo- } \\
\text { gy and Molecular Medicine }\end{array}$ & $\begin{array}{l}\text { Alpha }-181 \\
\text { Beta }-4 \\
\text { Gamma }-0 \\
\text { Delta }-6\end{array}$ & 480 & $\begin{array}{l}\text { Alpha }-37,7 \\
\text { Beta }-0,8 \\
\text { Gamma }-0 \\
\text { Delta }-1,2\end{array}$ & $\begin{array}{l}\text { Alpha }-21 \\
\text { Beta }-0 \\
\text { Gamma }-0 \\
\text { Delta }-2\end{array}$ & 28 & $\begin{array}{l}\text { Alpha }-75 \\
\text { Beta }-0 \\
\text { Gamma }-0 \\
\text { Delta }-7,1\end{array}$ \\
\hline $\begin{array}{c}\text { Центральноафрикан- } \\
\text { ская Республика } \\
\text { (стабилизация } \\
\text { заболеваемости) }\end{array}$ & $\begin{array}{l}\text { Pathogen Sequencing Lab, National } \\
\text { Institute for Biomedical Research } \\
\text { (INRB) }\end{array}$ & $\begin{array}{l}\text { Alpha }-2 \\
\text { Beta }-0 \\
\text { Gamma }-0 \\
\text { Delta }-0\end{array}$ & 11 & $\begin{array}{l}\text { Alpha }-18,2 \\
\text { Beta }-0 \\
\text { Gamma }-0 \\
\text { Delta }-0\end{array}$ & $\begin{array}{l}\text { Alpha }-0 \\
\text { Beta }-0 \\
\text { Gamma }-0 \\
\text { Delta }-0\end{array}$ & 0 & $\begin{array}{l}\text { Alpha }-0 \\
\text { Beta }-0 \\
\text { Gamma }-0 \\
\text { Delta }-0\end{array}$ \\
\hline $\begin{array}{c}\text { Эквадор } \\
\text { (стабилизация } \\
\text { заболеваемости) }\end{array}$ & $\begin{array}{l}\text { Instituto Nacional de Investi- } \\
\text { gaciónenSaludPública, INSPI }\end{array}$ & $\begin{array}{l}\text { Alpha }-103 \\
\text { Beta }-1 \\
\text { Gamma }-32 \\
\text { Delta }-0\end{array}$ & 616 & $\begin{array}{l}\text { Alpha }-16,7 \\
\text { Beta }-0,2 \\
\text { Gamma }-5,2 \\
\text { Delta }-0\end{array}$ & $\begin{array}{l}\text { Alpha }-6 \\
\text { Beta }-0 \\
\text { Gamma }-9 \\
\text { Delta }-0\end{array}$ & 89 & $\begin{array}{l}\text { Alpha }-6,7 \\
\text { Beta }-0 \\
\text { Gamma }-10,1 \\
\text { Delta }-0\end{array}$ \\
\hline $\begin{array}{c}\text { Экваториальная Гвинея } \\
\text { (стабилизация } \\
\text { заболеваемости) }\end{array}$ & $\begin{array}{l}\text { Swiss Tropical and Public Health } \\
\text { Institute }\end{array}$ & $\begin{array}{l}\text { Alpha }-1 \\
\text { Beta }-43 \\
\text { Gamma }-0 \\
\text { Delta }-0\end{array}$ & 191 & $\begin{array}{l}\text { Alpha }-0,5 \\
\text { Beta }-22,5 \\
\text { Gamma }-0 \\
\text { Delta }-0\end{array}$ & $\begin{array}{l}\text { Alpha }-0 \\
\text { Beta }-0 \\
\text { Gamma }-0 \\
\text { Delta }-0\end{array}$ & 0 & $\begin{array}{l}\text { Alpha }-0 \\
\text { Beta }-0 \\
\text { Gamma }-0 \\
\text { Delta }-0 \\
\end{array}$ \\
\hline $\begin{array}{c}\text { Эсватини } \\
\text { (рост заболеваемости) }\end{array}$ & $\begin{array}{l}\text { Nhlangano Health Centre (National } \\
\text { Institute for Communicable Dis- } \\
\text { eases of the National Health Labor- } \\
\text { atory Service) }\end{array}$ & $\begin{array}{l}\text { Alpha }-0 \\
\text { Beta }-26 \\
\text { Gamma }-0 \\
\text { Delta }-0\end{array}$ & 33 & $\begin{array}{l}\text { Alpha }-0 \\
\text { Beta }-78,8 \\
\text { Gamma }-0 \\
\text { Delta }-0\end{array}$ & $\begin{array}{l}\text { Alpha }-0 \\
\text { Beta }-0 \\
\text { Gamma }-0 \\
\text { Delta }-0\end{array}$ & 0 & $\begin{array}{l}\text { Alpha }-0 \\
\text { Beta }-0 \\
\text { Gamma }-0 \\
\text { Delta }-0\end{array}$ \\
\hline $\begin{array}{c}\text { Эстония } \\
\text { (снижение } \\
\text { заболеваемости) }\end{array}$ & $\begin{array}{l}\text { Laboratory of Communicable Dis- } \\
\text { eases (Estonia); } \\
\text { Eurofins Genomics Europe Se- } \\
\text { quencing GmbH }\end{array}$ & $\begin{array}{l}\text { Alpha }-2685 \\
\text { Beta }-37 \\
\text { Gamma }-0 \\
\text { Delta }-0\end{array}$ & $\begin{array}{c}397 \\
1\end{array}$ & $\begin{array}{l}\text { Alpha }-67,6 \\
\text { Beta }-1 \\
\text { Gamma }-0 \\
\text { Delta }-0\end{array}$ & $\begin{array}{l}\text { Alpha }-0 \\
\text { Beta }-0 \\
\text { Gamma }-0 \\
\text { Delta }-0\end{array}$ & 0 & $\begin{array}{l}\text { Alpha }-0 \\
\text { Beta }-0 \\
\text { Gamma }-0 \\
\text { Delta }-0\end{array}$ \\
\hline $\begin{array}{c}\text { Эфиопия } \\
\text { (стабилизация } \\
\text { заболеваемости) }\end{array}$ & $\begin{array}{l}\text { International Centre for Genetic } \\
\text { Engineering and Biotechnology } \\
\text { (ICGEB) and ARGO Open Lab for } \\
\text { Genome Sequencing }\end{array}$ & $\begin{array}{l}\text { Alpha }-3 \\
\text { Beta }-0 \\
\text { Gamma }-0 \\
\text { Delta }-0\end{array}$ & 19 & $\begin{array}{l}\text { Alpha }-15,8 \\
\text { Beta }-0 \\
\text { Gamma }-0 \\
\text { Delta }-0\end{array}$ & $\begin{array}{l}\text { Alpha }-0 \\
\text { Beta }-0 \\
\text { Gamma }-0 \\
\text { Delta }-0\end{array}$ & 0 & $\begin{array}{l}\text { Alpha }-0 \\
\text { Beta }-0 \\
\text { Gamma }-0 \\
\text { Delta }-0\end{array}$ \\
\hline
\end{tabular}




\begin{tabular}{|c|c|c|c|c|c|c|c|}
\hline $\begin{array}{c}\text { ЮАР } \\
\text { (рост } \\
\text { заболеваемости) }\end{array}$ & $\begin{array}{l}\text { KRISP, KZN Research Innovation } \\
\text { and Sequencing Platform. }\end{array}$ & $\begin{array}{l}\text { Alpha }-53 \\
\text { Beta }-5173 \\
\text { Gamma }-0 \\
\text { Delta }-25\end{array}$ & $\begin{array}{c}896 \\
7\end{array}$ & $\begin{array}{l}\text { Alpha }-0,6 \\
\text { Beta }-57,7 \\
\text { Gamma }-0 \\
\text { Delta }-0,2\end{array}$ & $\begin{array}{l}\text { Alpha }-0 \\
\text { Beta }-10 \\
\text { Gamma }-0 \\
\text { Delta }-0\end{array}$ & 21 & $\begin{array}{l}\text { Alpha }-0 \\
\text { Beta }-47,7 \\
\text { Gamma }-0 \\
\text { Delta }-0\end{array}$ \\
\hline $\begin{array}{l}\text { Южная Корея } \\
\text { (снижение } \\
\text { заболеваемости) }\end{array}$ & $\begin{array}{l}\text { Division of Emerging Infectious } \\
\text { Diseases, Bureau of Infectious Dis- } \\
\text { eases Diagnosis Control, Korea } \\
\text { Disease Control and Prevention } \\
\text { Agency }\end{array}$ & $\begin{array}{l}\text { Alpha }-579 \\
\text { Beta }-17 \\
\text { Gamma }-3 \\
\text { Delta }-20\end{array}$ & $\begin{array}{c}631 \\
9\end{array}$ & $\begin{array}{l}\text { Alpha }-9,1 \\
\text { Beta }-0,3 \\
\text { Gamma }-0,05 \\
\text { Delta }-0,3\end{array}$ & $\begin{array}{l}\text { Alpha }-0 \\
\text { Beta }-0 \\
\text { Gamma }-0 \\
\text { Delta }-1\end{array}$ & 2 & $\begin{array}{l}\text { Alpha }-0 \\
\text { Beta }-0 \\
\text { Gamma }-0 \\
\text { Delta }-50\end{array}$ \\
\hline $\begin{array}{c}\text { Ямайка } \\
\text { (стабилизация } \\
\text { заболеваемости) }\end{array}$ & $\begin{array}{l}\text { Carrington Lab, Department of } \\
\text { PreClinical Sciences, Faculty of } \\
\text { Medical Sciences, The University } \\
\text { of the West Indies }\end{array}$ & $\begin{array}{l}\text { Alpha }-7 \\
\text { Beta }-0 \\
\text { Gamma }-0 \\
\text { Delta }-0\end{array}$ & 29 & $\begin{array}{l}\text { Alpha }-24,1 \\
\text { Beta }-0 \\
\text { Gamma }-0 \\
\text { Delta }-0\end{array}$ & $\begin{array}{l}\text { Alpha }-0 \\
\text { Beta }-0 \\
\text { Gamma }-0 \\
\text { Delta }-0\end{array}$ & 0 & $\begin{array}{l}\text { Alpha }-0 \\
\text { Beta }-0 \\
\text { Gamma }-0 \\
\text { Delta }-0\end{array}$ \\
\hline $\begin{array}{c}\text { Япония } \\
\text { (снижение } \\
\text { заболеваемости) }\end{array}$ & $\begin{array}{l}\text { Pathogen Genomics Center, Na- } \\
\text { tional Institute of Infectious Dis- } \\
\text { eases }\end{array}$ & $\begin{array}{l}\text { Alpha - } \\
11888 \\
\text { Beta }-75 \\
\text { Gamma }-104 \\
\text { Delta }-197\end{array}$ & $\begin{array}{c}493 \\
30\end{array}$ & $\begin{array}{l}\text { Alpha }-24 \\
\text { Beta }-0,1 \\
\text { Gamma }-0,2 \\
\text { Delta }-0,4\end{array}$ & $\begin{array}{l}\text { Alpha }-61 \\
\text { Beta }-7 \\
\text { Gamma }-2 \\
\text { Delta }-26\end{array}$ & 114 & $\begin{array}{l}\text { Alpha }-53,5 \\
\text { Beta }-6,1 \\
\text { Gamma }-1,7 \\
\text { Delta }-22,8\end{array}$ \\
\hline
\end{tabular}


Таблица 2 - Количество депонированных геномов варианта Epsilon GH/452R.V1 (B.1.429/B.1.427) и варианта Eta G/484K.V3 (B.1.525) вируса SARS-CoV-2 в базе GISAID.

\begin{tabular}{|c|c|c|c|c|c|c|c|}
\hline \multirow[b]{2}{*}{$\begin{array}{c}\text { Страна } \\
\text { (тренд заболе- } \\
\text { ваемости по } \\
\text { данным ЕСДС) }\end{array}$} & \multirow[b]{2}{*}{$\begin{array}{c}\text { Учреждение, } \\
\text { проводившее секвениро- } \\
\text { вание }\end{array}$} & \multicolumn{3}{|c|}{$\begin{array}{c}\text { Количество депонированных геномов } \\
\text { SARS-CoV-2 }\end{array}$} & \multicolumn{3}{|c|}{$\begin{array}{c}\text { В том числе количество геномов, депо- } \\
\text { нированных за последние } 4 \text { недели } \\
(15.05 .21-11.06 .21) \\
\end{array}$} \\
\hline & & $\begin{array}{l}\quad \text { Варианты: } \\
\text { Epsilon } \\
\text { (B.1.429/B.1.427) } \\
\text { Eta }(\text { B.1.525) }\end{array}$ & Всего & $\begin{array}{c}\text { Процент гено- } \\
\text { мов, относя- } \\
\text { щихся к вари- } \\
\quad \text { анту: } \\
\text { Epsilon } \\
\text { (B.1.429/B.1.427) } \\
\text { Eta (B.1.525) }\end{array}$ & $\begin{array}{l}\quad \text { Варианты: } \\
\text { Epsilon } \\
\text { (B.1.429/B.1.427) } \\
\text { Eta (B.1.525) }\end{array}$ & $\begin{array}{l}\text { Bce- } \\
\text { го }\end{array}$ & $\begin{array}{l}\text { Процент гено- } \\
\text { мов, относящих- } \\
\text { ся к варианту: } \\
\text { Epsilon } \\
\text { (B.1.429/B.1.427) } \\
\text { Eta (B.1.525) }\end{array}$ \\
\hline $\begin{array}{c}\text { Ангилья } \\
\text { (стабилизация } \\
\text { заболеваемости) }\end{array}$ & $\begin{array}{l}\text { Carrington Lab, Department } \\
\text { of PreClinical Sciences, Fac- } \\
\text { ul-ty of Medical Sciences, } \\
\text { The University of the West } \\
\text { Indies }\end{array}$ & $\begin{array}{l}\text { Epsilon - } 1 \\
\text { Iota }-1\end{array}$ & 5 & $\begin{array}{l}\text { Epsilon }-20,0 \\
\quad \text { Iota }-20\end{array}$ & $\begin{array}{l}\text { Epsilon - } 0 \\
\text { Iota }-0\end{array}$ & 5 & $\begin{array}{l}\text { Epsilon }-0 \\
\text { Iota }-0\end{array}$ \\
\hline $\begin{array}{c}\text { Ангола } \\
\text { (стабилизация } \\
\text { заболеваемости) }\end{array}$ & $\begin{array}{l}\text { KRISP, KZN Research Inno- } \\
\text { vation and Sequencing Plat- } \\
\text { form }\end{array}$ & $\begin{array}{c}\text { Eta }-4 \\
\text { Kappa }-24\end{array}$ & 663 & $\begin{array}{c}\text { Eta }-0,7 \\
\text { Kappa }-3,6\end{array}$ & $\begin{array}{c}\text { Eta }-0 \\
\text { Kappa }-0\end{array}$ & 0 & $\begin{array}{c}\text { Eta }-0 \\
\text { Kappa }-0\end{array}$ \\
\hline $\begin{array}{c}\text { Аргентина } \\
\text { (снижение забо- } \\
\text { леваемости) }\end{array}$ & $\begin{array}{l}\text { Instituto Nacional Enferme- } \\
\text { dadesInfecciosasC.G.Malbran }\end{array}$ & $\begin{array}{l}\text { Epsilon }-26 \\
\text { Eta }-1 \\
\text { Iota }-8 \\
\text { Lambda }-86\end{array}$ & 4214 & $\begin{array}{l}\text { Epsilon }-0,6 \\
\text { Eta }-0,02 \\
\text { Iota }-0,2 \\
\text { Lambda }-2,0\end{array}$ & $\begin{array}{l}\text { Epsilon - 0 } \\
\text { Eta }-0 \\
\text { Iota }-0 \\
\text { Lambda }-0\end{array}$ & 0 & $\begin{array}{l}\text { Epsilon }-0 \\
\text { Eta }-0 \\
\text { Iota }-0 \\
\text { Lambda }-0\end{array}$ \\
\hline $\begin{array}{c}\text { Аруба } \\
\text { (снижение забо- } \\
\text { леваемости) }\end{array}$ & $\begin{array}{l}\text { National Institute for Public } \\
\text { Health and the Environment } \\
\text { (RIVM) }\end{array}$ & $\begin{array}{l}\text { Epsilon }-49 \\
\text { Iota }-97 \\
\text { Lambda }-1\end{array}$ & 1142 & $\begin{array}{c}\text { Epsilon }-4,3 \\
\text { Iota }-8,4 \\
\text { Lambda }-0,1\end{array}$ & $\begin{array}{l}\text { Epsilon - 0 } \\
\text { Iota }-7 \\
\text { Lambda -0 }\end{array}$ & 134 & $\begin{array}{l}\text { Epsilon - } 0 \\
\text { Iota }-5,2 \\
\text { Lambda -0 }\end{array}$ \\
\hline
\end{tabular}




\begin{tabular}{|c|c|c|c|c|c|c|c|}
\hline $\begin{array}{c}\text { Австралия } \\
\text { (стабилизация } \\
\text { заболеваемости) }\end{array}$ & $\begin{array}{l}\text { NSW Health Pathology - In- } \\
\text { stitute of Clinical Pathology } \\
\text { and Medical Research; } \\
\text { Westmead Hospital; Universi- } \\
\text { ty of Sydney }\end{array}$ & $\begin{array}{c}\text { Epsilon - 3 } \\
\text { Eta }-15 \\
\text { Theta }-2 \\
\text { Iota }-6 \\
\text { Kappa }-110 \\
\text { Lambda }-1\end{array}$ & 18110 & $\begin{array}{c}\text { Epsilon }-0,01 \\
\text { Eta }-0,1 \\
\text { Theta }-0,01 \\
\text { Iota }-0,03 \\
\text { Kappa }-0,6 \\
\text { Lambda }-0,0\end{array}$ & $\begin{array}{l}\text { Epsilon }-0 \\
\text { Eta }-2 \\
\text { Theta }-0 \\
\text { Iota }-0 \\
\text { Kappa }-46 \\
\text { Lambda }-0\end{array}$ & 148 & $\begin{array}{c}\text { Epsilon - } 0 \\
\text { Eta }-1,7 \\
\text { Theta }-0 \\
\text { Iota }-0,0 \\
\text { Kappa }-31,0 \\
\text { Lambda }-0\end{array}$ \\
\hline $\begin{array}{c}\text { Австрия } \\
\text { (стабилизация } \\
\text { заболеваемости) }\end{array}$ & $\begin{array}{l}\text { Bergthaler laboratory, CeMM } \\
\text { Research Center for Molecu- } \\
\text { lar Medicine of the Austrian } \\
\text { Academy of Sciences }\end{array}$ & $\begin{array}{c}\text { Eta }-17 \\
\text { Iota }-2 \\
\text { Kappa }-1\end{array}$ & 16840 & $\begin{array}{c}\text { Eta }-0,1 \\
\text { Iota }-0,01 \\
\text { Kappa }-0,01\end{array}$ & $\begin{array}{c}\text { Eta }-0 \\
\text { Iota }-0 \\
\text { Kappa }-0\end{array}$ & 227 & $\begin{array}{c}\text { Eta }-0 \\
\text { Iota }-0 \\
\text { Kappa }-0\end{array}$ \\
\hline $\begin{array}{c}\text { Бангладеш } \\
\text { (рост заболева- } \\
\text { емости) }\end{array}$ & $\begin{array}{l}\text { Child Health Research Foun- } \\
\text { dation }\end{array}$ & Eta -14 & 1749 & Eta $-0,8$ & $\mathrm{Eta}-0$ & 52 & Eta -0 \\
\hline $\begin{array}{c}\text { Барбадос } \\
\text { (стабилизация } \\
\text { заболеваемости) }\end{array}$ & $\begin{array}{l}\text { Carrington Lab, Department } \\
\text { of PreClinical Sciences, } \\
\text { Building 36, First Floor Bio- } \\
\text { chemistry Unit, Fac-ulty of } \\
\text { Medical Sciences, The Uni- } \\
\text { versity of the West Indies }\end{array}$ & Epsilon - 1 & 18 & Epsilon - 5,5 & Epsilon - 0 & 0 & Epsilon - 0 \\
\hline $\begin{array}{c}\text { Бахрейн } \\
\text { (снижение забо- } \\
\text { леваемости) }\end{array}$ & $\begin{array}{l}\text { Communicable Disease La- } \\
\text { boratory, Public Health Direc- } \\
\text { torate }\end{array}$ & Карра -8 & 218 & Карра - 3,7 & Kappa - 0 & 6 & Карра -0 \\
\hline $\begin{array}{c}\text { Бельгия } \\
\text { (снижение забо- } \\
\text { леваемости) }\end{array}$ & $\begin{array}{l}\text { KU Leuven, Rega Institute, } \\
\text { Clinical and Epidemiological } \\
\text { Virology }\end{array}$ & $\begin{array}{l}\text { Epsilon }-1 \\
\text { Eta }-66 \\
\text { Iota }-8 \\
\text { Kappa }-10\end{array}$ & 27910 & $\begin{array}{c}\text { Epsilon }-0,003 \\
\text { Eta }-0,2 \\
\text { Iota }-0,02 \\
\text { Kappa }-0,03\end{array}$ & $\begin{array}{l}\text { Epsilon - } 0 \\
\text { Eta }-1 \\
\text { Iota }-0 \\
\text { Kappa }-0\end{array}$ & 2254 & $\begin{array}{l}\text { Epsilon - 0 } \\
\text { Eta }-0,04 \\
\text { Iota }-0 \\
\text { Kappa }-0\end{array}$ \\
\hline
\end{tabular}




\begin{tabular}{|c|c|c|c|c|c|c|c|}
\hline $\begin{array}{c}\text { Беларусь } \\
\text { (стабилизация } \\
\text { заболеваемости) }\end{array}$ & $\begin{array}{l}\text { Laboratory for HIV and op- } \\
\text { portunistic infections diagno- } \\
\text { sis The Republican Research } \\
\text { and Practical Center for Epi- } \\
\text { demiology and Microbiology } \\
\text { (RRPCEM) }\end{array}$ & Eta -1 & 47 & Eta $-2,1$ & Eta -0 & 0 & $\mathrm{Eta}-0$ \\
\hline $\begin{array}{c}\text { Бразилия } \\
\text { (рост заболева- } \\
\text { емости) } \\
\end{array}$ & $\begin{array}{l}\text { Instituto Adolfo Lutz, Interdi- } \\
\text { ciplinary Procedures Center, } \\
\text { Strategic Laboratory }\end{array}$ & $\begin{array}{c}\text { Eta }-1 \\
\text { Lambda }-3\end{array}$ & 18620 & $\begin{array}{c}\text { Eta }-0,01 \\
\text { Lambda }-0,01\end{array}$ & $\begin{array}{c}\text { Eta }-0 \\
\text { Lambda }-0\end{array}$ & 499 & $\begin{array}{c}\text { Eta }-0 \\
\text { Lambda }-0\end{array}$ \\
\hline $\begin{array}{c}\text { Британские } \\
\text { Виргинские } \\
\text { острова } \\
\text { (стабилизация } \\
\text { заболеваемости) } \\
\end{array}$ & $\begin{array}{l}\text { Caribbean Public Health } \\
\text { Agency }\end{array}$ & Iota -1 & 11 & Iota -10 & Iota -0 & 0 & Iota -0 \\
\hline $\begin{array}{c}\text { Великобрита- } \\
\text { ния } \\
\text { (рост заболева- } \\
\text { емости) }\end{array}$ & $\begin{array}{l}\text { COVID-19 Genomics UK } \\
\text { (COG-UK) Consortium. } \\
\text { Wellcome Sanger Institute for } \\
\text { the COVID-19 Genomics UK } \\
\text { (COG-UK) consortium. }\end{array}$ & $\begin{array}{c}\text { Epsilon }-8 \\
\text { Eta }-472 \\
\text { Theta }-7 \\
\text { Iota }-38 \\
\text { Kappa }-407 \\
\text { Lambda }-6 \\
\end{array}$ & 476400 & $\begin{array}{c}\text { Epsilon }-0,001 \\
\text { Eta }-0,1 \\
\text { Theta }-0,001 \\
\text { Iota }-0,01 \\
\text { Kappa }-0,08 \\
\text { Lambda }-0,001\end{array}$ & $\begin{array}{l}\text { Epsilon - } 0 \\
\text { Eta }-17 \\
\text { Theta }-1 \\
\text { Iota }-0 \\
\text { Kappa }-10 \\
\text { Lambda }-1\end{array}$ & $\begin{array}{c}4798 \\
0\end{array}$ & $\begin{array}{c}\text { Epsilon }-0,0 \\
\text { Eta }-0,03 \\
\text { Theta }-0,001 \\
\text { Iota }-0 \\
\text { Kappa }-0,02 \\
\text { Lambda }-0,002\end{array}$ \\
\hline $\begin{array}{c}\text { Венесуэла } \\
\text { (стабилизация } \\
\text { заболеваемости) }\end{array}$ & $\begin{array}{l}\text { Laboratorio de Virología Mo- } \\
\text { lecular }\end{array}$ & Iota -1 & 148 & Iota $-0,6$ & Iota -0 & 1 & Iota -0 \\
\hline $\begin{array}{c}\text { Габон } \\
\text { (стабилизация } \\
\text { заболеваемости) }\end{array}$ & $\begin{array}{l}\text { Centre de Recherches Médi- } \\
\text { cales de Lambaréné } \\
\text { (CERMEL) }\end{array}$ & Eta -1 & 205 & Eta $-0,5$ & Eta -0 & 0 & $\mathrm{Eta}-0$ \\
\hline
\end{tabular}




\begin{tabular}{|c|c|c|c|c|c|c|c|}
\hline $\begin{array}{c}\text { Гана } \\
\text { (стабилизация } \\
\text { заболеваемости) }\end{array}$ & $\begin{array}{l}\text { Department of Biochemistry, } \\
\text { Cell and Molecular Biology, } \\
\text { West African Centre for Cell } \\
\text { Biology of Infectious Patho- } \\
\text { gens (WACCBIP), University } \\
\text { of Ghana }\end{array}$ & $\begin{array}{l}\text { Eta }-38 \\
\text { Iota }-2 \\
\text { Kappa }-5\end{array}$ & 698 & $\begin{array}{c}\text { Eta }-5,4 \\
\text { Iota }-0,2 \\
\text { Kappa }-0,7\end{array}$ & $\begin{array}{c}\text { Eta }-0 \\
\text { Iota }-0 \\
\text { Kappa }-0\end{array}$ & 0 & $\begin{array}{c}\text { Eta }-0 \\
\text { Iota }-0 \\
\text { Kappa }-0\end{array}$ \\
\hline $\begin{array}{c}\text { Гамбия } \\
\text { (стабилизация } \\
\text { заболеваемости) } \\
\end{array}$ & $\begin{array}{l}\text { MRCG at LSHTM Genomics } \\
\text { lab }\end{array}$ & Eta -1 & 472 & Eta $-0,2$ & Eta -0 & 0 & Eta -0 \\
\hline Гваделупа & $\begin{array}{l}\text { National Reference Center for } \\
\text { Viruses of Respiratory Infec- } \\
\text { tions, Institut Pasteur, Paris }\end{array}$ & $\begin{array}{l}\text { Epsilon - 3 } \\
\text { Eta }-2 \\
\text { Iota }-1 \\
\text { Kappa }-2\end{array}$ & 145 & $\begin{array}{c}\text { Epsilon }-2,1 \\
\text { Eta }-1,4 \\
\text { Iota }-0,7 \\
\text { Kappa }-1,4\end{array}$ & $\begin{array}{c}\text { Epsilon - 0 } \\
\text { Eta }-0 \\
\text { Iota }-0 \\
\text { Kappa }-0\end{array}$ & 18 & $\begin{array}{l}\text { Epsilon - } 0 \\
\text { Eta }-0 \\
\text { Iota }-0 \\
\text { Kappa }-0\end{array}$ \\
\hline $\begin{array}{c}\text { Гвинея } \\
\text { (стабилизация } \\
\text { заболеваемости) }\end{array}$ & $\begin{array}{l}\text { Centre de Recherche et de } \\
\text { Formation en Infectiologie } \\
\text { Guinée }\end{array}$ & Eta -5 & 40 & $\mathrm{Eta}-12,5$ & Eta -0 & 0 & Eta -0 \\
\hline $\begin{array}{c}\text { Германия } \\
\text { (снижение забо- } \\
\text { леваемости) }\end{array}$ & $\begin{array}{l}\text { Charité Universitätsmedizin } \\
\text { Berlin, InstitutfürVirologie. } \\
\text { Institute of infectious medi- } \\
\text { cine \& hospital hygiene, } \\
\text { CaSe-Group. }\end{array}$ & $\begin{array}{c}\text { Epsilon - } 4 \\
\text { Eta }-637 \\
\text { Theta }-9 \\
\text { Iota }-55 \\
\text { Kappa }-99 \\
\text { Lambda }-87\end{array}$ & 134500 & $\begin{array}{c}\text { Epsilon }-0,01 \\
\text { Eta }-0,5 \\
\text { Theta }-0,01 \\
\text { Iota }-0,04 \\
\text { Kappa }-0,07 \\
\text { Lambda }-0,06\end{array}$ & $\begin{array}{c}\text { Epsilon }-0 \\
\text { Eta }-18 \\
\text { Theta }-0 \\
\text { Iota }-5 \\
\text { Kappa }-3 \\
\text { Lambda }-18\end{array}$ & 7877 & $\begin{array}{c}\text { Epsilon }-0,0 \\
\text { Eta }-0,2 \\
\text { Theta }-0 \\
\text { Iota }-0,06 \\
\text { Kappa }-0,03 \\
\text { Lambda }-0,2\end{array}$ \\
\hline $\begin{array}{c}\text { Гренада } \\
\text { (стабилизация } \\
\text { заболеваемости) } \\
\end{array}$ & $\begin{array}{l}\text { The Caribbean Public Health } \\
\text { Agency }\end{array}$ & Iota -2 & 7 & Iota $-28,5$ & Iota -0 & 2 & Iota -0 \\
\hline $\begin{array}{c}\text { Греция } \\
\text { (снижение забо- } \\
\text { леваемости) }\end{array}$ & $\begin{array}{l}\text { Greek Genome Center, Bio- } \\
\text { medical Research Foundation } \\
\text { of the Academy of Athens } \\
\text { (BRFAA) }\end{array}$ & $\begin{array}{c}\text { Eta }-2 \\
\text { Kappa }-1\end{array}$ & 7742 & $\begin{array}{c}\text { Eta }-0,03 \\
\text { Kappa }-0,01\end{array}$ & $\begin{array}{c}\text { Eta }-0 \\
\text { Kappa }-0\end{array}$ & 96 & $\begin{array}{c}\text { Eta }-0 \\
\text { Kappa }-0\end{array}$ \\
\hline
\end{tabular}




\begin{tabular}{|c|c|c|c|c|c|c|c|}
\hline $\begin{array}{c}\text { Гуам } \\
\text { (стабилизация } \\
\text { заболеваемости) }\end{array}$ & $\begin{array}{l}\text { Centers for Disease Control } \\
\text { and Prevention Division of } \\
\text { Viral Diseases, Pathogen Dis- } \\
\text { covery }\end{array}$ & Epsilon - 8 & 60 & Epsilon - 13,3 & Epsilon - 0 & 0 & Epsilon - 0 \\
\hline $\begin{array}{c}\text { Дания } \\
\text { (снижение забо- } \\
\text { леваемости) }\end{array}$ & $\begin{array}{l}\text { Albertsen lab, Department of } \\
\text { Chemistry and Bioscience, } \\
\text { Aalborg University. } \\
\text { Department of Virus and Mi- } \\
\text { crobiological Special Diag- } \\
\text { nostics, Statens Serum Insti- } \\
\text { tut. }\end{array}$ & $\begin{array}{c}\text { Epsilon }-13 \\
\text { Eta }-613 \\
\text { Iota }-8 \\
\text { Kappa }-27 \\
\text { Lambda }-1\end{array}$ & 105600 & $\begin{array}{c}\text { Epsilon }-0,01 \\
\text { Eta }-0,6 \\
\text { Iota }-0,01 \\
\text { Kappa }-0,02 \\
\text { Lambda }-0,001\end{array}$ & $\begin{array}{l}\text { Epsilon - 0 } \\
\text { Eta }-1 \\
\text { Iota }-0 \\
\text { Kappa - 0 } \\
\text { Lambda -0 }\end{array}$ & 7327 & $\begin{array}{c}\text { Epsilon - } 0 \\
\text { Eta }-0,1 \\
\text { Iota }-0 \\
\text { Kappa -0 } \\
\text { Lambda -0 }\end{array}$ \\
\hline $\begin{array}{c}\text { Доминикан- } \\
\text { ская Республи- } \\
\text { ка } \\
\text { (стабилизация } \\
\text { заболеваемости) }\end{array}$ & $\begin{array}{l}\text { Respiratory Viruses Branch, } \\
\text { Centers for Disease Control } \\
\text { and Prevention, USA }\end{array}$ & $\begin{array}{c}\text { Iota }-8 \\
\text { Lambda }-1\end{array}$ & 79 & $\begin{array}{c}\text { Iota }-10,1 \\
\text { Lambda }-1,3\end{array}$ & $\begin{array}{c}\text { Iota }-2 \\
\text { Lambda }-0\end{array}$ & 3 & $\begin{array}{l}\text { Iota }-66,7 \\
\text { Lambda }-0\end{array}$ \\
\hline $\begin{array}{c}\text { Египет } \\
\text { (стабилизация } \\
\text { заболеваемости) }\end{array}$ & $\begin{array}{l}\text { Main Chemical Laboratories } \\
\text { Egypt Army }\end{array}$ & Lambda -8 & 967 & Lambda $-0,8$ & Lambda -0 & 0 & Lambda -0 \\
\hline $\begin{array}{c}\text { Зимбабве } \\
\text { (рост заболева- } \\
\text { емости) }\end{array}$ & $\begin{array}{l}\text { National Microbiology Refer- } \\
\text { ence Laboratory (Quadram } \\
\text { Institute Bio-science) }\end{array}$ & Lambda -1 & 558 & Lambda $-0,1$ & Lambda -0 & 0 & Lambda -0 \\
\hline
\end{tabular}




\begin{tabular}{|c|c|c|c|c|c|c|c|}
\hline $\begin{array}{c}\text { Израиль } \\
\text { (рост заболева- } \\
\text { емости) }\end{array}$ & $\begin{array}{l}\text { Central Virology Laboratory, } \\
\text { Israel Ministry of Health }\end{array}$ & $\begin{array}{c}\text { Epsilon - } 8 \\
\text { Eta }-15 \\
\text { Iota }-9 \\
\text { Lambda }-19\end{array}$ & 12170 & $\begin{array}{c}\text { Epsilon }-0,1 \\
\text { Eta }-0,1 \\
\text { Iota }-0,07 \\
\text { Lambda }-0,1\end{array}$ & $\begin{array}{l}\text { Epsilon - 0 } \\
\text { Eta }-0 \\
\text { Iota }-0 \\
\text { Lambda -0 }\end{array}$ & 68 & $\begin{array}{l}\text { Epsilon - 0 } \\
\text { Eta }-0 \\
\text { Iota }-0 \\
\text { Lambda -0 }\end{array}$ \\
\hline $\begin{array}{c}\text { Индия } \\
\text { (снижение забо- } \\
\text { леваемости) }\end{array}$ & $\begin{array}{l}\text { Department of Neurovirolo- } \\
\text { gy, National Institute of Men- } \\
\text { tal Health and Neurosciences } \\
\text { (NIMHANS). } \\
\text { CSIR-Centre for Cellular and } \\
\text { Molecular Biology }\end{array}$ & $\begin{array}{c}\text { Epsilon - } 1 \\
\text { Eta }-184 \\
\text { Iota }-3 \\
\text { Kappa }-3520\end{array}$ & 28150 & $\begin{array}{c}\text { Epsilon }-0,01 \\
\text { Eta }-0,7 \\
\text { Iota }-0,01 \\
\text { Kappa }-12,5\end{array}$ & $\begin{array}{c}\text { Epsilon }-0 \\
\text { Eta }-1 \\
\text { Iota }-0 \\
\text { Kappa }-0\end{array}$ & 203 & $\begin{array}{c}\text { Epsilon - 0 } \\
\text { Eta }-0,4 \\
\text { Iota }-0 \\
\text { Kappa }-0\end{array}$ \\
\hline $\begin{array}{c}\text { Индонезия } \\
\text { (рост заболева- } \\
\text { емости) }\end{array}$ & $\begin{array}{l}\text { National Institute of Health } \\
\text { Research and Development }\end{array}$ & $\begin{array}{c}\text { Eta }-4 \\
\text { Iota }-2 \\
\text { Kappa }-2\end{array}$ & 2305 & $\begin{array}{c}\text { Eta }-0,2 \\
\text { Iota }-0,08 \\
\text { Kappa }-0,08\end{array}$ & $\begin{array}{c}\text { Eta }-0 \\
\text { Iota }-0 \\
\text { Kappa }-0\end{array}$ & 250 & $\begin{array}{c}\text { Eta }-0 \\
\text { Iota }-0 \\
\text { Kappa }-0\end{array}$ \\
\hline $\begin{array}{c}\text { Иордания } \\
\text { (стабилизация } \\
\text { заболеваемости) }\end{array}$ & $\begin{array}{l}\text { Andersen lab at Scripps Re- } \\
\text { search, CA, USA }\end{array}$ & $\begin{array}{c}\text { Eta }-2 \\
\text { Kappa }-4\end{array}$ & 654 & $\begin{array}{c}\text { Eta }-0,3 \\
\text { Kappa }-0,6\end{array}$ & $\begin{array}{c}\text { Eta }-0 \\
\text { Kappa }-0\end{array}$ & 0 & $\begin{array}{c}\text { Eta }-0 \\
\text { Kappa }-0\end{array}$ \\
\hline $\begin{array}{c}\text { Ирландия } \\
\text { (снижениет за- } \\
\text { болеваемости) }\end{array}$ & $\begin{array}{l}\text { National Virus Reference La- } \\
\text { boratory }\end{array}$ & $\begin{array}{c}\text { Epsilon - } 7 \\
\text { Eta }-65 \\
\text { Iota }-13 \\
\text { Kappa }-147\end{array}$ & 16830 & $\begin{array}{c}\text { Epsilon }-0,04 \\
\text { Eta }-0,4 \\
\text { Iota }-0,07 \\
\text { Kappa }-0,8\end{array}$ & $\begin{array}{l}\text { Epsilon - 0 } \\
\text { Eta }-4 \\
\text { Iota }-0 \\
\text { Kappa - } 5\end{array}$ & 681 & $\begin{array}{c}\text { Epsilon - 0 } \\
\text { Eta }-0,4 \\
\text { Iota }-0 \\
\text { Kappa }-0,7\end{array}$ \\
\hline $\begin{array}{c}\text { Испания } \\
\text { (снижение забо- } \\
\text { леваемости) }\end{array}$ & $\begin{array}{l}\text { Hospital Universitario } 12 \text { de } \\
\text { Octubre }\end{array}$ & $\begin{array}{c}\text { Epsilon - 5 } \\
\text { Eta }-153 \\
\text { Iota }-111 \\
\text { Kappa - 5 } \\
\text { Lambda -42 }\end{array}$ & 35070 & $\begin{array}{c}\text { Epsilon }-0,01 \\
\text { Eta }-0,4 \\
\text { Iota }-0,3 \\
\text { Kappa }-0,01 \\
\text { Lambda }-0,1\end{array}$ & $\begin{array}{c}\text { Epsilon - } 1 \\
\text { Eta }-6 \\
\text { Iota }-16 \\
\text { Kappa }-0 \\
\text { Lambda }-11\end{array}$ & 1811 & $\begin{array}{c}\text { Epsilon }-0,06 \\
\text { Eta }-0,3 \\
\text { Iota }-0,8 \\
\text { Kappa }-0 \\
\text { Lambda }-0,6\end{array}$ \\
\hline
\end{tabular}




\begin{tabular}{|c|c|c|c|c|c|c|c|}
\hline $\begin{array}{c}\text { Италия } \\
\text { (снижение забо- } \\
\text { леваемости) }\end{array}$ & $\begin{array}{l}\text { Army Medical Center, Scien- } \\
\text { tific Department, Virology } \\
\text { Laboratory }\end{array}$ & $\begin{array}{l}\text { Epsilon - } 1 \\
\text { Eta }-338 \\
\text { Iota }-6 \\
\text { Kappa }-7 \\
\text { Lambda }-5\end{array}$ & 32970 & $\begin{array}{c}\text { Epsilon }-0,01 \\
\text { Eta }-1,1 \\
\text { Iota }-0,01 \\
\text { Kappa }-0,02 \\
\text { Lambda }-0,01\end{array}$ & $\begin{array}{l}\text { Epsilon - 0 } \\
\text { Eta }-3 \\
\text { Iota }-0 \\
\text { Kappa }-0 \\
\text { Lambda -3 }\end{array}$ & 1275 & $\begin{array}{c}\text { Epsilon }-0 \\
\text { Eta }-0,2 \\
\text { Iota }-0 \\
\text { Kappa }-0 \\
\text { Lambda }-0,2\end{array}$ \\
\hline $\begin{array}{c}\text { Камбоджа } \\
\text { (стабилизация } \\
\text { заболеваемости) } \\
\end{array}$ & $\begin{array}{l}\text { Virology Unit, Institut Pasteur } \\
\text { du Cambodge }\end{array}$ & $\begin{array}{l}\text { Epsilon - } 2 \\
\text { Kappa - } 1\end{array}$ & 372 & $\begin{array}{c}\text { Epsilon }-0,6 \\
\text { Kappa }-0,3\end{array}$ & $\begin{array}{l}\text { Epsilon - 0 } \\
\text { Kappa - 0 }\end{array}$ & 89 & $\begin{array}{l}\text { Epsilon - } 0 \\
\text { Kappa - } 0\end{array}$ \\
\hline $\begin{array}{c}\text { Камерун } \\
\text { (стабилизация } \\
\text { заболеваемости) }\end{array}$ & $\begin{array}{l}\text { CREMER(Centre de Recher- } \\
\text { cherches sur les Maladies } \\
\text { Emergentes et Ré- } \\
\text { émergentes) }\end{array}$ & $\begin{array}{l}\text { Epsilon - } 4 \\
\text { Eta - } 6 \\
\text { Lambda -1 }\end{array}$ & 204 & $\begin{array}{l}\text { Epsilon }-1,9 \\
\text { Eta }-2,9 \\
\text { Lambda }-0,5\end{array}$ & $\begin{array}{l}\text { Epsilon - } 0 \\
\text { Eta - } 0 \\
\text { Lambda -0 }\end{array}$ & 0 & $\begin{array}{l}\text { Epsilon - 0 } \\
\text { Eta - } 0 \\
\text { Lambda -0 }\end{array}$ \\
\hline $\begin{array}{c}\text { Канада } \\
\text { (снижение забо- } \\
\text { леваемости) }\end{array}$ & $\begin{array}{l}\text { Laboratoire de santé publique } \\
\text { du Québec }\end{array}$ & $\begin{array}{l}\text { Epsilon - } 25 \\
\text { Eta }-1341 \\
\text { Iota }-150 \\
\text { Kappa }-241 \\
\text { Lambda }-3\end{array}$ & 45560 & $\begin{array}{c}\text { Epsilon }-0,05 \\
\text { Eta }-3,1 \\
\text { Iota }-0,3 \\
\text { Kappa }-0,5 \\
\text { Lambda }-0,01\end{array}$ & $\begin{array}{l}\text { Epsilon - 0 } \\
\text { Eta - 0 } \\
\text { Iota }-0 \\
\text { Kappa }-0 \\
\text { Lambda -0 }\end{array}$ & 0 & $\begin{array}{l}\text { Epsilon - 0 } \\
\text { Eta - 0 } \\
\text { Iota }-0 \\
\text { Kappa - 0 } \\
\text { Lambda -0 }\end{array}$ \\
\hline $\begin{array}{c}\text { Катар } \\
\text { (снижение забо- } \\
\text { леваемости) }\end{array}$ & $\begin{array}{l}\text { Ministry of Public Health / } \\
\text { Hamad Medical Corporation }\end{array}$ & $\begin{array}{l}\text { Epsilon - } 11 \\
\text { Eta - } 1 \\
\text { Kappa }-10\end{array}$ & 2452 & $\begin{array}{c}\text { Epsilon }-0,5 \\
\text { Eta }-0,04 \\
\text { Kappa }-0,4\end{array}$ & $\begin{array}{l}\text { Epsilon - 0 } \\
\text { Eta - 0 } \\
\text { Kappa - 0 }\end{array}$ & 0 & $\begin{array}{l}\text { Epsilon - 0 } \\
\text { Eta - } 0 \\
\text { Kappa - } 0\end{array}$ \\
\hline $\begin{array}{c}\text { Каймановы } \\
\text { острова } \\
\text { (рост заболева- } \\
\text { емости) }\end{array}$ & $\begin{array}{l}\text { Carrington Lab, Department } \\
\text { of PreClinical Sciences, } \\
\text { Building 36, First Floor Bio- } \\
\text { chemistry Unit, Fac-ulty of } \\
\text { Medical Sciences, The Uni- } \\
\text { versity of the West Indies }\end{array}$ & Iota -1 & 9 & Iota $-11,1$ & Iota -0 & 2 & Iota -0 \\
\hline $\begin{array}{c}\text { Кения } \\
\text { (рост заболева- } \\
\text { емости) } \\
\end{array}$ & $\begin{array}{l}\text { KEMRI-Wellcome Trust Re- } \\
\text { search Programme/KEMRI- } \\
\text { CGMR-C Kilifi }\end{array}$ & Карра - 5 & 1468 & Карра - 0,3 & Kappa - 0 & 22 & Kappa - 0 \\
\hline
\end{tabular}




\begin{tabular}{|c|c|c|c|c|c|c|c|}
\hline $\begin{array}{c}\text { Китай } \\
\text { (стабилизация } \\
\text { заболеваемости) }\end{array}$ & $\begin{array}{l}\text { National Institute for Viral } \\
\text { Disease Control and Preven- } \\
\text { tion }\end{array}$ & $\begin{array}{c}\text { Theta }-10 \\
\text { Iota }-1 \\
\text { Kappa }-9\end{array}$ & 3097 & $\begin{array}{c}\text { Theta }-0,3 \\
\text { Iota }-0,03 \\
\text { Kappa }-0,3\end{array}$ & $\begin{array}{c}\text { Theta }-0 \\
\text { Iota }-0 \\
\text { Kappa }-0\end{array}$ & 31 & $\begin{array}{c}\text { Theta }-0 \\
\text { Iota }-0 \\
\text { Kappa }-0\end{array}$ \\
\hline $\begin{array}{c}\text { Колумбия } \\
\text { (стабилизация } \\
\text { заболеваемости) }\end{array}$ & $\begin{array}{l}\text { Instituto Nacional de Salud- } \\
\text { Dirección de Investigación en } \\
\text { Salud Pública }\end{array}$ & $\begin{array}{c}\text { Epsilon - } 1 \\
\text { Iota }-108 \\
\text { Lambda }-14\end{array}$ & 1692 & $\begin{array}{c}\text { Epsilon }-0,06 \\
\text { Iota }-6,3 \\
\text { Lambda }-0,8\end{array}$ & $\begin{array}{l}\text { Epsilon - } 0 \\
\text { Iota }-0 \\
\text { Lambda }-0\end{array}$ & 13 & $\begin{array}{l}\text { Epsilon - } 0 \\
\text { Iota }-0 \\
\text { Lambda }-0\end{array}$ \\
\hline $\begin{array}{c}\text { Коста-Рика } \\
\text { (снижение забо- } \\
\text { леваемости) }\end{array}$ & $\begin{array}{l}\text { Inciensa, Instituto Costarri- } \\
\text { cense de Investigación y } \\
\text { Enseñanza en Nutrición y } \\
\text { Salud }\end{array}$ & $\begin{array}{l}\text { Epsilon - } 9 \\
\text { Eta - } 4 \\
\text { Iota }-4\end{array}$ & 641 & $\begin{array}{c}\text { Epsilon }-1,4 \\
\text { Eta }-0,7 \\
\text { Iota }-0,6\end{array}$ & $\begin{array}{l}\text { Epsilon - 0 } \\
\text { Eta - } 0 \\
\text { Iota }-0\end{array}$ & 0 & $\begin{array}{l}\text { Epsilon - 0 } \\
\text { Eta - } 0 \\
\text { Iota }-0\end{array}$ \\
\hline $\begin{array}{c}\text { Кот-д'Ивуар } \\
\text { (стабилизация } \\
\text { заболеваемости) }\end{array}$ & $\begin{array}{l}\text { Molecular diagnostic unit for } \\
\text { viral haemorrhagic fevers and } \\
\text { emerging viruses, Bouaké } \\
\text { CHU Laboratory }\end{array}$ & Eta - 10 & 145 & Eta $-6,9$ & Eta - 0 & 0 & Eta - 0 \\
\hline $\begin{array}{c}\text { Кувейт } \\
\text { (рост заболева- } \\
\text { емости) }\end{array}$ & $\begin{array}{l}\text { Virology Unit, Department of } \\
\text { Mi-crobiology, Faculty of } \\
\text { Medicine, Kuwait }\end{array}$ & Eta - 2 & 47 & Eta $-4,3$ & Eta - 2 & 5 & Eta -40 \\
\hline $\begin{array}{c}\text { Кюрасао } \\
\text { (рост заболева- } \\
\text { емости) }\end{array}$ & $\begin{array}{l}\text { Dutch COVID-19 response } \\
\text { team }\end{array}$ & $\begin{array}{l}\text { Epsilon - } 1 \\
\text { Iota }-1 \\
\text { Kappa }-1 \\
\text { Lambda }-1\end{array}$ & 423 & $\begin{array}{c}\text { Epsilon }-0,2 \\
\text { Iota }-0,2 \\
\text { Kappa }-0,2 \\
\text { Lambda }-0,2\end{array}$ & $\begin{array}{l}\text { Epsilon - 0 } \\
\text { Iota }-0 \\
\text { Kappa }-0 \\
\text { Lambda -0 }\end{array}$ & 1 & $\begin{array}{l}\text { Epsilon - 0 } \\
\text { Iota }-0 \\
\text { Kappa -0 } \\
\text { Lambda -0 }\end{array}$ \\
\hline $\begin{array}{c}\text { Латвия } \\
\text { (снижение забо- } \\
\text { леваемости) } \\
\end{array}$ & $\begin{array}{l}\text { Latvian Biomedical Research } \\
\text { and Study Centre }\end{array}$ & Eta - 1 & 3350 & $\mathrm{Eta}-0,03$ & Eta - 0 & 0 & Eta -0 \\
\hline $\begin{array}{c}\text { Литва } \\
\text { (снижение забо- } \\
\text { леваемости) } \\
\end{array}$ & $\begin{array}{l}\text { Vilnius University Hospital } \\
\text { San-taros Klinikos, Center of } \\
\text { Laborato-ry Medicine }\end{array}$ & Iota -8 & 12680 & Iota $-0,06$ & Iota -1 & 604 & Iota $-0,1$ \\
\hline $\begin{array}{c}\text { Люксембург } \\
\text { (снижение } \\
\text { заболеваемости) }\end{array}$ & $\begin{array}{l}\text { Laboratoire national de santé, } \\
\text { Microbiology, Microbial Ge- } \\
\text { nomics Platform }\end{array}$ & $\begin{array}{c}\text { Eta }-50 \\
\text { Iota }-6 \\
\text { Kappa }-6\end{array}$ & 9133 & $\begin{array}{c}\text { Eta }-0,5 \\
\text { Iota }-0,06 \\
\text { Kappa }-0,06\end{array}$ & $\begin{array}{c}\text { Eta }-1 \\
\text { Iota }-0 \\
\text { Kappa }-0\end{array}$ & 5 & $\begin{array}{c}\text { Eta }-0,6 \\
\text { Iota }-0 \\
\text { Kappa }-0\end{array}$ \\
\hline
\end{tabular}




\begin{tabular}{|c|c|c|c|c|c|c|c|}
\hline Майотта & $\begin{array}{l}\text { National Reference Center for } \\
\text { Viruses of Respiratory Infec- } \\
\text { tions, Institut Pasteur, Paris }\end{array}$ & Eta - 2 & 705 & Eta $-0,3$ & Eta - 0 & 1 & Eta - 0 \\
\hline $\begin{array}{c}\text { Малайзия } \\
\text { (снижение забо- } \\
\text { леваемости) }\end{array}$ & $\begin{array}{l}\text { Institute for Medical Re- } \\
\text { search, Infectious Disease Re- } \\
\text { search Centre, National Insti- } \\
\text { tutes of Health, Ministry of } \\
\text { Health Malaysia }\end{array}$ & $\begin{array}{c}\text { Eta - } 3 \\
\text { Theta }-10 \\
\text { Kappa }-1\end{array}$ & 1303 & $\begin{array}{c}\text { Eta }-0,2 \\
\text { Theta }-0,8 \\
\text { Kappa }-0,07\end{array}$ & $\begin{array}{c}\text { Eta }-0 \\
\text { Theta }-0 \\
\text { Kappa }-0\end{array}$ & 16 & $\begin{array}{c}\text { Eta }-0 \\
\text { Theta }-0 \\
\text { Kappa }-0\end{array}$ \\
\hline $\begin{array}{c}\text { Мальта } \\
\text { (стабилизация } \\
\text { заболеваемости) } \\
\end{array}$ & $\begin{array}{l}\text { Molecular Diagnostics Pa- } \\
\text { thology Department Mater } \\
\text { Dei Hospital Malta }\end{array}$ & Eta - 12 & 174 & Eta $-6,9$ & Eta - 0 & 13 & Eta - 0 \\
\hline $\begin{array}{c}\text { Марокко } \\
\text { (стабилизация } \\
\text { заболеваемости) } \\
\end{array}$ & $\begin{array}{l}\text { Laboratoire de Biotechnolo- } \\
\text { gie }\end{array}$ & Eta - 1 & 214 & Eta $-0,5$ & Eta - 0 & 0 & Eta - 0 \\
\hline $\begin{array}{c}\text { Мексика } \\
\text { (стабилизация } \\
\text { заболеваемости) }\end{array}$ & $\begin{array}{l}\text { Instituto de diagnóstico y } \\
\text { ReferenciaEpidemiologicos } \\
\text { (INDRE) }\end{array}$ & $\begin{array}{c}\text { Epsilon - } 218 \\
\text { Iota }-46 \\
\text { Kappa }-7 \\
\text { Lambda }-57\end{array}$ & 11780 & $\begin{array}{c}\text { Epsilon }-1,8 \\
\text { Iota }-0,4 \\
\text { Kappa }-0,05 \\
\text { Lambda }-0,4\end{array}$ & $\begin{array}{l}\text { Epsilon - } 2 \\
\text { Iota }-7 \\
\text { Kappa }-2 \\
\text { Lambda -3 }\end{array}$ & 522 & $\begin{array}{l}\text { Epsilon }-0,4 \\
\text { Iota }-1,3 \\
\text { Kappa }-0,3 \\
\text { Lambda }-0,6\end{array}$ \\
\hline $\begin{array}{c}\text { Мьянма } \\
\text { (стабилизация } \\
\text { заболеваемости) } \\
\end{array}$ & DSMRC & Карра - 4 & 20 & Kappa - 20,0 & Kappa - 3 & 10 & Kappa - 30 \\
\hline $\begin{array}{c}\text { Непал } \\
\text { (снижение забо- } \\
\text { леваемости) }\end{array}$ & $\begin{array}{l}\text { Molecular and Genomics Re- } \\
\text { search Lab, Dhulikhel Hospi- } \\
\text { tal, Kathmandu University } \\
\text { Hospital } \\
\text { School of Public Health, The } \\
\text { University of Hong Kong }\end{array}$ & Kappa - 2 & 64 & Карра - 3,1 & Kappa - 0 & 0 & Карра - 0 \\
\hline $\begin{array}{c}\text { Нигерия } \\
\text { (стабилизация } \\
\text { заболеваемости) }\end{array}$ & $\begin{array}{l}\text { African Centre of Excellence } \\
\text { for Genomics of Infectious } \\
\text { Diseases (ACEGID), Re- } \\
\text { deemer's University }\end{array}$ & Eta - 223 & 827 & $\mathrm{Eta}-27,0$ & Eta - 1 & 1 & Eta $-100,0$ \\
\hline
\end{tabular}




\begin{tabular}{|c|c|c|c|c|c|c|c|}
\hline $\begin{array}{c}\text { Нигер } \\
\text { (стабилизация } \\
\text { заболеваемости) }\end{array}$ & $\begin{array}{l}\text { National Reference Center for } \\
\text { Viruses of Respiratory Infec- } \\
\text { tions, Institut Pasteur, Paris }\end{array}$ & Eta - 6 & 6 & Eta $-100,0$ & Eta - 0 & 0 & Eta - 0 \\
\hline $\begin{array}{c}\text { Нидерланды } \\
\text { (снижение забо- } \\
\text { леваемости) }\end{array}$ & $\begin{array}{l}\text { National Institute for Public } \\
\text { Health and the Environment } \\
\text { (RIVM) }\end{array}$ & $\begin{array}{c}\text { Epsilon - } 4 \\
\text { Eta - 52 } \\
\text { Theta }-7 \\
\text { Iota }-5 \\
\text { Kappa - } 11 \\
\text { Lambda -1 }\end{array}$ & 39010 & $\begin{array}{c}\text { Epsilon }-0,01 \\
\text { Eta }-0,1 \\
\text { Theta }-0,01 \\
\text { Iota }-0,01 \\
\text { Kappa }-0,02 \\
\text { Lambda }-0,001\end{array}$ & $\begin{array}{l}\text { Epsilon - 0 } \\
\text { Eta - 0 } \\
\text { Theta - 0 } \\
\text { Iota -0 } \\
\text { Kappa - 1 } \\
\text { Lambda -0 }\end{array}$ & 1558 & $\begin{array}{c}\text { Epsilon - 0 } \\
\text { Eta - 0 } \\
\text { Theta - 0 } \\
\text { Iota -0 } \\
\text { Kappa - 0,06 } \\
\text { Lambda -0 }\end{array}$ \\
\hline $\begin{array}{c}\text { Новая Зелан- } \\
\text { дия } \\
\text { (стабилизация } \\
\text { заболеваемости) }\end{array}$ & $\begin{array}{l}\text { Institute of Environmental } \\
\text { Science and Research (ESR) }\end{array}$ & $\begin{array}{l}\text { Epsilon - } 4 \\
\text { Theta }-2 \\
\text { Iota }-1 \\
\text { Kappa }-4\end{array}$ & 1086 & $\begin{array}{l}\text { Epsilon }-0,4 \\
\text { Theta }-0,2 \\
\text { Iota }-0,1 \\
\text { Kappa }-0,3\end{array}$ & $\begin{array}{l}\text { Epsilon - 0 } \\
\text { Theta }-0 \\
\text { Iota }-0 \\
\text { Kappa }-0\end{array}$ & 11 & $\begin{array}{l}\text { Epsilon - } 0 \\
\text { Theta }-0 \\
\text { Iota }-0 \\
\text { Kappa }-0\end{array}$ \\
\hline $\begin{array}{c}\text { Норвегия } \\
\text { (снижение забо- } \\
\text { леваемости) }\end{array}$ & $\begin{array}{l}\text { Norwegian Institute of Public } \\
\text { Health, Department of Virol- } \\
\text { ogy }\end{array}$ & $\begin{array}{c}\text { Epsilon - } 1 \\
\text { Eta }-81 \\
\text { Theta }-2 \\
\text { Kappa }-1\end{array}$ & 12030 & $\begin{array}{c}\text { Epsilon }-0,001 \\
\text { Eta }-0,7 \\
\text { Theta }-0,01 \\
\text { Kappa }-0,001\end{array}$ & $\begin{array}{l}\text { Epsilon - } 0 \\
\text { Eta - } 0 \\
\text { Theta }-0 \\
\text { Kappa }-0\end{array}$ & 566 & $\begin{array}{l}\text { Epsilon - 0 } \\
\text { Eta }-0 \\
\text { Theta }-0 \\
\text { Kappa }-0\end{array}$ \\
\hline $\begin{array}{c}\text { Перу } \\
\text { (снижение забо- } \\
\text { леваемости) }\end{array}$ & $\begin{array}{l}\text { Laboratorio de Referencia } \\
\text { Nacional de Biotecnología y } \\
\text { Biología Molecular. Instituto } \\
\text { Nacional de SaludPerú }\end{array}$ & $\begin{array}{c}\text { Iota }-16 \\
\text { Lambda }-222\end{array}$ & 1433 & $\begin{array}{c}\text { Iota }-1,1 \\
\text { Lambda }-15,4\end{array}$ & $\begin{array}{c}\text { Iota }-0 \\
\text { Lambda }-2\end{array}$ & 3 & $\begin{array}{c}\text { Iota }-0 \\
\text { Lambda }-66,7\end{array}$ \\
\hline $\begin{array}{c}\text { Польша } \\
\text { (стабилизация } \\
\text { заболеваемости) } \\
\end{array}$ & $\begin{array}{l}\text { genXone SA, Research \& } \\
\text { Development Laboratory }\end{array}$ & $\begin{array}{l}\text { Eta }-9 \\
\text { Iota }-1\end{array}$ & 16420 & $\begin{array}{l}\text { Eta }-0,06 \\
\text { Iota }-0,001\end{array}$ & $\begin{array}{l}\text { Eta }-0 \\
\text { Iota }-0\end{array}$ & 709 & $\begin{array}{l}\text { Eta }-0 \\
\text { Iota }-0\end{array}$ \\
\hline $\begin{array}{c}\text { Португалия } \\
\text { (рост заболева- } \\
\text { емости) }\end{array}$ & $\begin{array}{l}\text { Instituto Nacional de Saude } \\
\text { (INSA) }\end{array}$ & $\begin{array}{c}\text { Eta }-20 \\
\text { Iota }-2 \\
\text { Kappa }-9 \\
\text { Lambda }-1 \\
\end{array}$ & 9251 & $\begin{array}{c}\text { Eta }-0,2 \\
\text { Iota }-0,02 \\
\text { Kappa }-0,09 \\
\text { Lambda }-0,01 \\
\end{array}$ & $\begin{array}{c}\text { Eta }-0 \\
\text { Iota }-0 \\
\text { Kappa }-0 \\
\text { Lambda -0 } \\
\end{array}$ & 520 & $\begin{array}{c}\text { Eta }-0 \\
\text { Iota }-0 \\
\text { Kappa }-0 \\
\text { Lambda }-0 \\
\end{array}$ \\
\hline
\end{tabular}




\begin{tabular}{|c|c|c|c|c|c|c|c|}
\hline $\begin{array}{c}\text { Республика } \\
\text { Малави } \\
\text { (стабилизация } \\
\text { заболеваемости) }\end{array}$ & $\begin{array}{l}\text { KRISP, KZN Research Inno- } \\
\text { vation and Sequencing Plat- } \\
\text { form }\end{array}$ & $\begin{array}{l}\text { Kappa }-2 \\
\text { Lambda }-1\end{array}$ & 336 & $\begin{array}{l}\text { Kappa }-0,6 \\
\text { Lambda }-0,4\end{array}$ & $\begin{array}{l}\text { Kappa - } 0 \\
\text { Lambda -0 }\end{array}$ & 0 & $\begin{array}{l}\text { Kappa - } 0 \\
\text { Lambda -0 }\end{array}$ \\
\hline $\begin{array}{c}\text { Республика } \\
\text { Маврикий } \\
\text { (снижение забо- } \\
\text { леваемости) }\end{array}$ & $\begin{array}{l}\text { CNR Virus des Infections } \\
\text { Res-piratoires - France SUD }\end{array}$ & Карpa - 3 & 133 & Карра - 2,2 & Карра - 0 & 0 & Карра - 0 \\
\hline Реюньон & $\begin{array}{l}\text { Université de la Réunion } \\
\text { Processus Infectieux en Mi- } \\
\text { lieu Insulaire Tropical (UMR } \\
\text { PIMIT) }\end{array}$ & Eta - 3 & 1142 & Eta $-0,3$ & Eta - 0 & 19 & Eta - 0 \\
\hline $\begin{array}{c}\text { Россия } \\
\text { (рост заболева- } \\
\text { емости) }\end{array}$ & $\begin{array}{l}\text { WHO National Influenza } \\
\text { Centre Russian Federation }\end{array}$ & $\begin{array}{c}\text { Eta }-1 \\
\text { Iota }-4 \\
\text { Kappa }-4\end{array}$ & 4977 & $\begin{array}{c}\text { Eta }-0,02 \\
\text { Iota }-0,08 \\
\text { Kappa }-0,08\end{array}$ & $\begin{array}{c}\text { Eta }-0 \\
\text { Iota }-0 \\
\text { Kappa }-0\end{array}$ & 137 & $\begin{array}{c}\text { Eta }-0 \\
\text { Iota }-0 \\
\text { Kappa }-0\end{array}$ \\
\hline $\begin{array}{c}\text { Руанда } \\
\text { (рост заболева- } \\
\text { емости) } \\
\end{array}$ & GIGA Medical Genomics & Eta -5 & 343 & Eta $-1,5$ & Eta - 0 & 0 & Eta - 0 \\
\hline $\begin{array}{c}\text { Румыния } \\
\text { (стабилизация } \\
\text { заболеваемости) }\end{array}$ & $\begin{array}{l}\text { National Institute of Infec- } \\
\text { tious Diseases-Prof. Dr. Matei } \\
\text { Bals Molecular Diagnostics } \\
\text { Laboratory } \\
\end{array}$ & Iota -2 & 996 & Iota $-0,2$ & Iota -0 & 69 & Iota -0 \\
\hline $\begin{array}{c}\text { Северная Ма- } \\
\text { кедония } \\
\text { (стабилизация } \\
\text { заболеваемости) }\end{array}$ & $\begin{array}{l}\text { Institute of Public Health of } \\
\text { Republic of North Macedonia } \\
\text { Laboratory of Virology and } \\
\text { Molecular Diagnostics }\end{array}$ & Epsilon - 1 & 534 & Epsilon - 0,2 & Epsilon - 0 & 0 & Epsilon - 0 \\
\hline $\begin{array}{l}\text { Северные Ма- } \\
\text { рианские о-ва }\end{array}$ & $\begin{array}{l}\text { Commonwealth Healthcare } \\
\text { Center }\end{array}$ & Epsilon - 1 & 62 & Epsilon - 1,6 & Epsilon - 0 & 0 & Epsilon - 0 \\
\hline
\end{tabular}




\begin{tabular}{|c|c|c|c|c|c|c|c|}
\hline $\begin{array}{c}\text { Сингапур } \\
\text { (стабилизация } \\
\text { заболеваемости) }\end{array}$ & $\begin{array}{l}\text { National Public Health La- } \\
\text { boratory, National Centre for } \\
\text { Infectious Diseases }\end{array}$ & $\begin{array}{c}\text { Epsilon - } 2 \\
\text { Eta - } 10 \\
\text { Theta }-3 \\
\text { Iota }-7 \\
\text { Kappa - 59 }\end{array}$ & 3210 & $\begin{array}{c}\text { Epsilon }-0,06 \\
\text { Eta }-0,3 \\
\text { Theta }-0,1 \\
\text { Iota }-0,2 \\
\text { Kappa - 2,0 }\end{array}$ & $\begin{array}{c}\text { Epsilon - 0 } \\
\text { Eta - } 0 \\
\text { Theta }-0 \\
\text { Iota }-0 \\
\text { Kappa - } 0\end{array}$ & 326 & $\begin{array}{c}\text { Epsilon - 0 } \\
\text { Eta - 0 } \\
\text { Theta }-0 \\
\text { Iota -0 } \\
\text { Kappa - } 0\end{array}$ \\
\hline $\begin{array}{c}\text { Синт-Мартен } \\
\text { (снижение забо- } \\
\text { леваемости) }\end{array}$ & $\begin{array}{l}\text { National Institute for Public } \\
\text { Health and the Environment } \\
\text { (RIVM) }\end{array}$ & $\begin{array}{l}\text { Epsilon - } 1 \\
\text { Iota }-17 \\
\text { Kappa }-2\end{array}$ & 344 & $\begin{array}{l}\text { Epsilon }-0,4 \\
\quad \text { Iota }-5 \\
\text { Kappa }-0,5\end{array}$ & $\begin{array}{l}\text { Epsilon - } 0 \\
\text { Iota }-1 \\
\text { Kappa }-0\end{array}$ & 78 & $\begin{array}{l}\text { Epsilon - 0 } \\
\text { Iota }-1,2 \\
\text { Kappa }-0\end{array}$ \\
\hline $\begin{array}{c}\text { Словакия } \\
\text { (снижение забо- } \\
\text { леваемости) }\end{array}$ & $\begin{array}{l}\text { Faculty of Natural Sciences, } \\
\text { Come-nius University }\end{array}$ & Карра - 1 & 3676 & Kappa $-0,02$ & Карра - 0 & 124 & Kappa - 0 \\
\hline $\begin{array}{c}\text { Словения } \\
\text { (снижение забо- } \\
\text { леваемости) }\end{array}$ & $\begin{array}{l}\text { Institute of Microbiology and } \\
\text { Immunology, Faculty of Med- } \\
\text { icine, University of Ljubljana }\end{array}$ & $\begin{array}{c}\text { Eta }-55 \\
\text { Iota }-3 \\
\text { Kappa }-1\end{array}$ & 14040 & $\begin{array}{c}\text { Eta }-0,4 \\
\text { Iota }-0,02 \\
\text { Kappa }-0,001\end{array}$ & $\begin{array}{c}\text { Eta }-0 \\
\text { Iota }-0 \\
\text { Kappa }-0\end{array}$ & 161 & $\begin{array}{c}\text { Eta - 0 } \\
\text { Iota }-0 \\
\text { Kappa }-0\end{array}$ \\
\hline $\begin{array}{c}\text { Суринам } \\
\text { (снижение забо- } \\
\text { леваемости) } \\
\end{array}$ & $\begin{array}{l}\text { National Institute for Public } \\
\text { Health and the Environment } \\
\text { (RIVM) }\end{array}$ & Iota -9 & 338 & Iota $-2,6$ & Iota -0 & 1 & Iota -0 \\
\hline $\begin{array}{c}\text { США } \\
\text { (снижение забо- } \\
\text { леваемости) }\end{array}$ & $\begin{array}{l}\text { Colorado Department of Pub- } \\
\text { lic Health \& Environment. } \\
\text { Maine Health and Environ- } \\
\text { mental Testing Laboratory. } \\
\text { California Department of } \\
\text { Public Health. UCSD } \\
\text { EXCITE. }\end{array}$ & $\begin{array}{c}\text { Epsilon - } 13732 \\
\text { Eta }-1108 \\
\text { Theta }-13 \\
\text { Iota }-44122 \\
\text { Kappa }-280 \\
\text { Lambda }-520\end{array}$ & 568073 & $\begin{array}{c}\text { Epsilon }-2,4 \\
\text { Eta }-0,2 \\
\text { Theta }-0,002 \\
\text { Iota }-7,7 \\
\text { Kappa }-0,05 \\
\text { Lambda -0,1 }\end{array}$ & $\begin{array}{c}\text { Epsilon - } 17 \\
\text { Eta - } 14 \\
\text { Theta }-2 \\
\text { Iota }-595 \\
\text { Kappa }-0 \\
\text { Lambda -12 }\end{array}$ & 9153 & $\begin{array}{c}\text { Epsilon }-0,2 \\
\text { Eta }-0,1 \\
\text { Theta }-0,01 \\
\text { Iota }-6,5 \\
\text { Kappa }-0 \\
\text { Lambda -0,1 }\end{array}$ \\
\hline $\begin{array}{c}\text { Таиланд } \\
\text { (стабилизация } \\
\text { заболеваемости) } \\
\end{array}$ & $\begin{array}{l}\text { COVID-19 Network Investi- } \\
\text { gations (CONI) Alliance }\end{array}$ & $\begin{array}{c}\text { Eta - } 2 \\
\text { Kappa }-1\end{array}$ & 1778 & $\begin{array}{c}\text { Eta }-0,1 \\
\text { Kappa }-0,05\end{array}$ & $\begin{array}{c}\text { Eta - 0 } \\
\text { Kappa }-0\end{array}$ & 39 & $\begin{array}{c}\text { Eta - 0 } \\
\text { Kappa - 0 }\end{array}$ \\
\hline
\end{tabular}




\begin{tabular}{|c|c|c|c|c|c|c|c|}
\hline $\begin{array}{c}\text { Тайвань } \\
\text { (снижение забо- } \\
\text { леваемости) }\end{array}$ & $\begin{array}{l}\text { Microbial Genomics Core } \\
\text { Lab, National Taiwan Univer- } \\
\text { sity Centers of Genomic and } \\
\text { Precision Medicine }\end{array}$ & Epsilon - 3 & 201 & Epsilon - 1,4 & Epsilon - 0 & 14 & Epsilon - 0 \\
\hline $\begin{array}{c}\text { Того } \\
\text { (стабилизация } \\
\text { заболеваемости) } \\
\end{array}$ & Institut National d'hygiène & Eta -23 & 125 & Eta $-18,4$ & Eta -0 & 0 & Eta - 0 \\
\hline $\begin{array}{c}\text { Тунис } \\
\text { (рост } \\
\text { заболеваемости) }\end{array}$ & $\begin{array}{l}\text { Pasteur Institute - Laboratory } \\
\text { of Clinical Virology }\end{array}$ & Eta - 1 & 116 & Eta $-0,8$ & Eta - 0 & 0 & Eta - 0 \\
\hline $\begin{array}{c}\text { Турция } \\
\text { (стабилизация } \\
\text { заболеваемости) }\end{array}$ & Ministry of Health Turkey & $\begin{array}{l}\text { Epsilon - } 2 \\
\text { Eta }-43 \\
\text { Iota }-4 \\
\text { Lambda -1 } \\
\end{array}$ & 5230 & $\begin{array}{c}\text { Epsilon }-0,04 \\
\text { Eta }-0,8 \\
\text { Iota }-0,07 \\
\text { Lambda }-0,01\end{array}$ & $\begin{array}{l}\text { Epsilon - 0 } \\
\text { Eta - } 0 \\
\text { Iota }-0 \\
\text { Lambda -0 }\end{array}$ & 20 & $\begin{array}{l}\text { Epsilon - 0 } \\
\text { Eta - 0 } \\
\text { Iota }-0 \\
\text { Lambda -0 }\end{array}$ \\
\hline $\begin{array}{c}\text { Уганда } \\
\text { (рост заболева- } \\
\text { емости) } \\
\end{array}$ & $\begin{array}{l}\text { MRC/UVRI \& LSHTM } \\
\text { Uganda Research Unit }\end{array}$ & $\begin{array}{c}\text { Eta }-18 \\
\text { Kappa }-1\end{array}$ & 428 & $\begin{array}{c}\text { Eta }-4,2 \\
\text { Kappa }-0,2\end{array}$ & $\begin{array}{c}\text { Eta }-0 \\
\text { Kappa }-0\end{array}$ & 0 & $\begin{array}{c}\text { Eta - 0 } \\
\text { Kappa - 0 }\end{array}$ \\
\hline $\begin{array}{c}\text { Уругвай } \\
\text { (снижение забо- } \\
\text { леваемости) }\end{array}$ & $\begin{array}{l}\text { Centro de Innovación en } \\
\text { Vigilancia Epidemiológica } \\
\text { (CiVE), Institut Pasteur Mon- } \\
\text { tevideo, Uruguay }\end{array}$ & Lambda -1 & 470 & Lambda $-0,2$ & Lambda -0 & 0 & Lambda -0 \\
\hline $\begin{array}{c}\text { Филиппины } \\
\text { (стабилизация } \\
\text { заболеваемости) }\end{array}$ & Philippine Genome Center & $\begin{array}{c}\text { Epsilon - } 2 \\
\text { Eta - } 6 \\
\text { Theta }-142\end{array}$ & 4305 & $\begin{array}{c}\text { Epsilon }-0,05 \\
\text { Eta }-0,1 \\
\text { Theta }-3,3\end{array}$ & $\begin{array}{l}\text { Epsilon - } 0 \\
\text { Eta - } 0 \\
\text { Theta }-0\end{array}$ & 0 & $\begin{array}{c}\text { Epsilon - 0 } \\
\text { Eta - } 0 \\
\text { Theta }-0\end{array}$ \\
\hline $\begin{array}{c}\text { Финляндия } \\
\text { (снижение забо- } \\
\text { леваемости) }\end{array}$ & $\begin{array}{l}\text { Department of Virology, Fac- } \\
\text { ulty of Medicine, University } \\
\text { of Helsinki }\end{array}$ & $\begin{array}{c}\text { Epsilon - } 1 \\
\text { Eta }-12 \\
\text { Iota }-1 \\
\text { Kappa }-7\end{array}$ & 11480 & $\begin{array}{c}\text { Epsilon }-0,01 \\
\text { Eta }-0,1 \\
\text { Iota }-0,01 \\
\text { Kappa }-0,06\end{array}$ & $\begin{array}{l}\text { Epsilon - } 0 \\
\text { Eta - } 0 \\
\text { Iota }-0 \\
\text { Kappa }-0\end{array}$ & 4 & $\begin{array}{l}\text { Epsilon - 0 } \\
\text { Eta - 0 } \\
\text { Iota }-0 \\
\text { Kappa }-0\end{array}$ \\
\hline
\end{tabular}




\begin{tabular}{|c|c|c|c|c|c|c|c|}
\hline $\begin{array}{c}\text { Франция } \\
\text { (снижение забо- } \\
\text { леваемости) }\end{array}$ & $\begin{array}{l}\text { CNR Virus des Infections } \\
\text { Respiratoires - France SUD }\end{array}$ & $\begin{array}{c}\text { Epsilon - } 4 \\
\text { Eta }-615 \\
\text { Iota }-8 \\
\text { Kappa }-15 \\
\text { Lambda }-13\end{array}$ & 45540 & $\begin{array}{c}\text { Epsilon }-0,01 \\
\text { Eta }-1,4 \\
\text { Iota }-0,01 \\
\text { Kappa }-0,03 \\
\text { Lambda }-0,02\end{array}$ & $\begin{array}{c}\text { Epsilon - 0 } \\
\text { Eta - 36 } \\
\text { Iota }-0 \\
\text { Kappa -0 } \\
\text { Lambda -4 }\end{array}$ & 3302 & $\begin{array}{c}\text { Epsilon - 0 } \\
\text { Eta }-1,5 \\
\text { Iota }-0,0 \\
\text { Kappa -0 } \\
\text { Lambda -0,1 }\end{array}$ \\
\hline $\begin{array}{c}\text { Хорватия } \\
\text { (снижение забо- } \\
\text { леваемости) } \\
\end{array}$ & $\begin{array}{l}\text { Croatian Institute of Public } \\
\text { Health }\end{array}$ & Iota -4 & 3121 & Iota $-0,1$ & Iota -0 & 0 & Iota -0 \\
\hline $\begin{array}{c}\text { Чехия } \\
\text { (снижение забо- } \\
\text { леваемости) }\end{array}$ & $\begin{array}{l}\text { The National Institute of Pub- } \\
\text { lic Health }\end{array}$ & Карра - 4 & 4434 & Карра - 0,1 & Kappa - 0 & 73 & Карра - 0 \\
\hline $\begin{array}{c}\text { Чили } \\
\text { (снижение забо- } \\
\text { леваемости) } \\
\end{array}$ & $\begin{array}{l}\text { Instituto de Salud Publica de } \\
\text { Chile }\end{array}$ & $\begin{array}{c}\text { Epsilon - } 2 \\
\text { Iota }-13 \\
\text { Lambda }-670 \\
\end{array}$ & 3575 & $\begin{array}{c}\text { Epsilon }-0,05 \\
\text { Iota }-0,3 \\
\text { Lambda }-18,7 \\
\end{array}$ & $\begin{array}{l}\text { Epsilon - } 0 \\
\text { Iota }-0 \\
\text { Lambda }-0 \\
\end{array}$ & 131 & $\begin{array}{l}\text { Epsilon - } 0 \\
\text { Iota }-0 \\
\text { Lambda }-0 \\
\end{array}$ \\
\hline $\begin{array}{c}\text { Швейцария } \\
\text { (снижение забо- } \\
\text { леваемости) }\end{array}$ & $\begin{array}{l}\text { Department of Biosystems } \\
\text { Science and Engineering, } \\
\text { ETH Zürich. }\end{array}$ & $\begin{array}{c}\text { Epsilon - } 4 \\
\text { Eta - 56 } \\
\text { Iota }-12 \\
\text { Kappa - } 11 \\
\text { Lambda -7 }\end{array}$ & 44760 & $\begin{array}{c}\text { Epsilon }-0,01 \\
\text { Eta }-0,1 \\
\text { Iota }-0,02 \\
\text { Kappa }-0,02 \\
\text { Lambda }-0,01\end{array}$ & $\begin{array}{c}\text { Epsilon - 0 } \\
\text { Eta - } 1 \\
\text { Iota }-0 \\
\text { Kappa - 0 } \\
\text { Lambda -0 }\end{array}$ & 1500 & $\begin{array}{c}\text { Epsilon - 0 } \\
\text { Eta }-0,0 \\
\text { Iota }-0 \\
\text { Kappa }-0 \\
\text { Lambda -0 }\end{array}$ \\
\hline $\begin{array}{c}\text { Швеция } \\
\text { (снижение забо- } \\
\text { леваемости) }\end{array}$ & $\begin{array}{l}\text { The Public Health Agency of } \\
\text { Sweden }\end{array}$ & $\begin{array}{l}\text { Epsilon - } 2 \\
\text { Eta - } 8 \\
\text { Iota }-4 \\
\text { Kappa - 5 }\end{array}$ & 68550 & $\begin{array}{c}\text { Epsilon }-0,003 \\
\text { Eta }-0,01 \\
\text { Iota }-0,01 \\
\text { Kappa }-0,0\end{array}$ & $\begin{array}{l}\text { Epsilon - 0 } \\
\text { Eta - 0 } \\
\text { Iota }-0 \\
\text { Kappa - 0 }\end{array}$ & 1076 & $\begin{array}{l}\text { Epsilon - } 0 \\
\text { Eta - } 0 \\
\text { Iota }-0 \\
\text { Kappa }-0\end{array}$ \\
\hline $\begin{array}{c}\text { Шри-Ланка } \\
\text { (снижение забо- } \\
\text { леваемости) }\end{array}$ & $\begin{array}{l}\text { Centre for Dengue Research } \\
\text { and AICBU, Department of } \\
\text { Immunology and Molecular } \\
\text { Medicine }\end{array}$ & Eta - 2 & 466 & Eta $-0,4$ & Eta - 0 & 33 & Eta - 0 \\
\hline $\begin{array}{c}\text { Эквадор } \\
\text { (стабилизация } \\
\text { заболеваемости) }\end{array}$ & $\begin{array}{l}\text { Instituto Nacional de Investi- } \\
\text { gaciónenSaludPública, INSPI }\end{array}$ & $\begin{array}{c}\text { Iota }-130 \\
\text { Lambda }-30\end{array}$ & 616 & $\begin{array}{c}\text { Iota }-21,1 \\
\text { Lambda }-4,8\end{array}$ & $\begin{array}{c}\text { Iota }-22 \\
\text { Lambda }-4\end{array}$ & 89 & $\begin{array}{c}\text { Iota }-24,7 \\
\text { Lambda }-4,5\end{array}$ \\
\hline
\end{tabular}




\begin{tabular}{|c|c|c|c|c|c|c|c|}
\hline $\begin{array}{c}\text { ЮАР } \\
\text { (рост заболева- } \\
\text { емости) }\end{array}$ & $\begin{array}{l}\text { KRISP, KZN Research Inno- } \\
\text { vation and Sequencing Plat- } \\
\text { form }\end{array}$ & $\begin{array}{c}\text { Eta - 5 } \\
\text { Kappa - } 1\end{array}$ & 8967 & $\begin{array}{c}\text { Eta }-0,05 \\
\text { Kappa }-0,01\end{array}$ & $\begin{array}{c}\text { Eta - 0 } \\
\text { Kappa - 0 }\end{array}$ & 21 & $\begin{array}{c}\text { Eta - 0 } \\
\text { Kappa - 0 }\end{array}$ \\
\hline $\begin{array}{l}\text { Южная Корея } \\
\text { (снижение забо- } \\
\text { леваемости) }\end{array}$ & $\begin{array}{l}\text { Division of Emerging Infec- } \\
\text { tious Diseases, Bureau of In- } \\
\text { fectious Diseases Diagnosis } \\
\text { Control, Korea Disease Con- } \\
\text { trol and Prevention Agency }\end{array}$ & $\begin{array}{l}\text { Epsilon - } 13 \\
\text { Eta }-2 \\
\text { Theta }-1 \\
\text { Iota }-4 \\
\text { Kappa }-12\end{array}$ & 6319 & $\begin{array}{l}\text { Epsilon }-0,2 \\
\text { Eta }-0,03 \\
\text { Theta }-0,01 \\
\text { Iota }-0,06 \\
\text { Kappa }-0,2\end{array}$ & $\begin{array}{l}\text { Epsilon - 0 } \\
\text { Eta - 0 } \\
\text { Theta }-0 \\
\text { Iota }-0 \\
\text { Kappa - 0 }\end{array}$ & 2 & $\begin{array}{l}\text { Epsilon - 0 } \\
\text { Eta - 0 } \\
\text { Theta }-0 \\
\text { Iota }-0 \\
\text { Kappa - 0 }\end{array}$ \\
\hline $\begin{array}{c}\text { Южный Судан } \\
\text { (стабилизация } \\
\text { заболеваемости) }\end{array}$ & $\begin{array}{l}\text { South Sudan Ministry of } \\
\text { Health, WHO South Sudan, } \\
\text { MRC/UVRI \& LSHTM } \\
\text { Uganda Research Unit }\end{array}$ & Eta - 32 & 45 & Eta $-71,1$ & Eta - 0 & 0 & Eta - 0 \\
\hline $\begin{array}{c}\text { Япония } \\
\text { (снижение забо- } \\
\text { леваемости) }\end{array}$ & $\begin{array}{l}\text { Pathogen Genomics Center, } \\
\text { National Institute of Infec- } \\
\text { tious Diseases }\end{array}$ & $\begin{array}{c}\text { Epsilon - } 2 \\
\text { Eta }-16 \\
\text { Theta }-4 \\
\text { Iota }-4 \\
\text { Kappa }-25\end{array}$ & 49330 & $\begin{array}{c}\text { Epsilon }-0,004 \\
\text { Eta }-0,03 \\
\text { Theta }-0,0 \\
\text { Iota }-0 \\
\text { Kappa }-0,05\end{array}$ & $\begin{array}{l}\text { Epsilon - 0 } \\
\text { Eta - 0 } \\
\text { Theta }-0 \\
\text { Iota }-0 \\
\text { Kappa - 0 }\end{array}$ & 114 & $\begin{array}{l}\text { Epsilon - 0 } \\
\text { Eta - 0 } \\
\text { Theta }-0 \\
\text { Iota }-0 \\
\text { Kappa - 0 }\end{array}$ \\
\hline $\begin{array}{c}\text { Ямайка } \\
\text { (стабилизация } \\
\text { заболеваемости) }\end{array}$ & $\begin{array}{l}\text { Carrington Lab, Department } \\
\text { of PreClinical Sciences, Fac- } \\
\text { ulty of Medical Sciences, The } \\
\text { University of the West Indies }\end{array}$ & Iota -2 & 29 & Iota $-6,9$ & Iota -0 & 0 & Iota -0 \\
\hline
\end{tabular}




\section{Вариант «Дельта Плюс»}

Вариант, получивший в Индии название «Дельта Плюс», впервые был опубликован в бюллетене Министерства общественного здравоохранения Англии [11 июня 2021 г.]. Эта сублиния варианта Дельта, впервые обнаруженного в Индии, которая приобрела мутацию K417N в S белке. Данная мутация типична для варианта Бета, впервые идентифицированном в Южной Африке. Некоторые ученые опасаются, что мутация в сочетании с другими существующими особенностями варианта Дельта может сделать его более передаваемым. «Мутация K417N представляет интерес, поскольку она присутствует в Бета-варианте (линия В.1.351), который, как сообщается, обладает свойством уклонения от иммунитета», - говорится в заявлении министерства здравоохранения Индии.

В техническом сообщении № 16 от 18 июня 2021 года сделанном в Великобритании (Public Health England. SARS-CoV-2 variants of concern and variants under investigation in England. Technical briefing 16), на основании информации по депонированным геномам SARS-CoV-2 в базу GISAID, предполагается, что существует как минимум 2 отдельные линии варианта Дельта с мутацией K417N. Одна линия с обозначением AY.1 уже зафиксирована во многих странах. Вторая линия, обнаруженная в последовательностях, загруженных в GISAID из США, обозначена как AY.2.

По состоянию на 16 июня 2021 г. не менее 197 геномов вируса относящегося к «Дельта Плюс», было депонировано из 11 стран: Великобритания (36), Канада (1), Индия (8), Япония (15), Непале (3), Польша (9), Португалия (22), Россия (1), Швейцария (18), Турция (1) и США (83).

На сегодняшний день в базе GISAID депонированы 285 геномов линии Дельта с мутацией K417N, то есть относящихся к варианту «Дельта плюс», которые включают в себя 186 геномов SARS-CoV-2 линии AY.1 и 104 генома линии АY.2. Анализ данных геномов показывает их полную идентичность по 
маркерным мутациям в S белке (K417N, L452R, T478K, D614G и P681R), однако они имеют несколько отличий по мутациям в других генах.

Первые геномы SARS-CoV-2 варианта «Дельта плюс» депонированы в марте 2021 года из Турции (2 генома, или 0,0005\% из общих 385600). В апреле варианты «Дельта плюс» депонированы из Индии, США, Великобритании, России, Японии, Непала, Ботсваны, Польши (19 геномов, или 0,005\% из общих 356213). В мае данные варианты депонированы из Индии, США, Beликобритании, Португалии, Японии, Непала, Германии, Польши, Швейцарии, Франции (160 геномов, или 0,07\% из общих 228617). За июнь - США, Швейцария, Непала, Япония, Португалия (93 генома, или 0,16\% из общих 58874). По количеству депонированных геномов можно сделать вывод о неуклонном росте числа вирусов SARS-CoV-2 варианта «Дельта плюс».

Главное, значимое отличие варианта Дельта от «Дельта плюс», наличие у последнего мутации K417N. Эта мутация в гене шиповидного белка, приводит к замене аминокислоты лизин (К) на аминокислоту аспарагин $(\mathrm{N})$ в позиции 417, которая находится в рецептор-связывающем домене (receptorbinding domain - RBD), функционально обеспечивающем связывание вириона с рецепторами на поверхности клеток человека. Высказываются предположения, что мутация K417N может способствовать снижению активности сыворотки и антител к вирусу у переболевших и вакцинированных людей, что помогает вирусу проникать и инфицировать клетки человека.

Индия сообщила 23 июня 2021 года, что около 40 случаев заболевания связанных с вариантом «Дельта плюс» было зарегистрировано в штатах Махараштра, Керала и Мадхья-Прадеш, без «значительного увеличения распространенности».

Самый ранний случай в Индии идентифицировали из образца, взятого 5 апреля 2021 года. Великобритания сообщила, что ее первые 5 случаев относились к 26 апреля 2021 года, и это были контакты лиц, которые приехали из Непала и Турции или проехали через них. 
В Индии и во всем мире продолжаются исследования по проверке эффективности вакцин против варианта «Дельта плюс».

«ВОЗ отслеживает этот вариант как часть варианта Дельта, вызывающих озабоченность, с дополнительными мутациями», - говорится в заявлении Всемирной организации здравоохранения (ВО3), отправленном информационному агентству Reuters. «На данный момент этот вариант не кажется распространенным, поскольку в настоящее время составляет лишь небольшую часть варианта Дельта. Но министерство здравоохранения Индии предупредило, что в регионах, где он был обнаружен, «возможно, потребуется усилить ответные меры общественного здравоохранения, сосредоточив внимание на эпиднадзоре, улучшенном тестировании, быстром отслеживании контактов и приоритетной вакцинации».

https://www.bbc.com/news/world-asia-india-57564560

Дельта плюс Индия: ученые утверждают, что рано говорить о риске варианта Covid-19

Soutik Biswas, Корреспондент DDC в Индии

24.06.2021

Индия классифицировала новый вариант коронавируса, впервые выявленный в Европе, как «вариант, вызывающий беспокойство», но еще слишком рано говорить о том, представляет ли он значительную угрозу. Министерство здравоохранения Индии заявляет, что исследования показали, что так называемый вариант Дельта плюс, также известный как AY.1, легче распространяется, легче связывается с клетками легких и потенциально устойчив к терапии моноклональными антителами. Этот вариант ассоциирован с вариантом Дельта, вариантом, вызывающим озабоченность (VOC), который впервые был выявлен в Индии в прошлом году и, как считается, стал причиной второй смертоносной волны инфекций этим летом в Индии. Министерство здравоохранения сообщает, что вариант Delta plus, впервые обнаруженный в Индии в апреле, был выявлен примерно в 40 образцах из шести райо- 
нов трех штатов - Махараштры, Кералы и Мадхья-Прадеша. По крайней меpe, 16 из этих образцов были обнаружены в Махараштре, одном из штатов, наиболее пострадавших от пандемии.

https://twitter.com/WHO/status/1408087054634799106

Главный научный сотрудник ВО3 Soumya Swaminathan 24 июня дала интервью в твиттере ВОЗ, в ходе которого ответила на вопросы, касающиеся вариантов SARS-CoV-2 и вакцин.

На вопрос о варианте дельта плюс (является ли он VOC или VOI) доктор Swaminathan ответила, что этот вариант дельта, у которого выявлена дополнительная мутацию, ранее определенная у вариантов гамма и бета.

Эта мутация потенциально может повысить резистентность этого варианта к антителам и лекарственным препаратам, а также к вакцинам. 
ВОЗ. Еженедельное эпидемиологическое обновление от 22 июня

Особое внимание: обновленная информация о вариантах SARSCoV-2, вызывающих интерес (VOI) и вариантах, вызывающих озабоченность (VOC)

BO3 обновила список глобальных VOI и VOC (таблица 3), а так же описание фенотипических проявлений (таблица 4) чтобы способствовать установлению приоритетов для эпиднадзора и исследований и, в конечном итоге, определять стратегии реагирования. Национальные органы власти могут выбрать другие варианты, представляющие интерес / озабоченность на местном уровне, и им предлагается исследовать и сообщать о влиянии этих вариантов. Здесь мы предоставляем обновленную информацию о глобально охарактеризованных VOC и VOI, а также обновленные страны/территории/районы (рисунок 4), сообщающие об обнаружении VOC.

Четыре текущих VOC (Альфа, Бета, Гамма и Дельта), за которыми ведется тщательный мониторинг, широко распространены и были обнаружены во всех регионах ВОЗ. Вариант Дельта распространяется значительно быстрее, чем вариант Альфа, и ожидается, что он станет доминирующей линией, если текущие тенденции сохранятся.

Таблица 3. Варианты SARS-CoV-2, вызывающие озабоченность (VOC), и варианты, представляющие интерес (VOI), по состоянию на 22 июня 2021 г.

\begin{tabular}{|l|l|l|l|l|l|}
\hline $\begin{array}{l}\text { Наименование } \\
\text { ВО3 }\end{array}$ & $\begin{array}{l}\text { Линия } \\
\text { Pango }\end{array}$ & $\begin{array}{l}\text { Клада } \\
\text { GISAID }\end{array}$ & $\begin{array}{l}\text { Клада } \\
\text { Nexstrain }\end{array}$ & $\begin{array}{l}\text { Самые ранние } \\
\text { зарегистриро- } \\
\text { ванные образцы }\end{array}$ & $\begin{array}{l}\text { Дата } \\
\text { обозна- } \\
\text { чения }\end{array}$ \\
\hline Альфа & В.1.1.7 & $\begin{array}{l}\text { GRY (paнеe } \\
\text { GR/501Y.V1) }\end{array}$ & 20I (V1) & $\begin{array}{l}\text { Великобритания, } \\
\text { сентябрь 2020 }\end{array}$ & $\begin{array}{l}18 \text { де- } \\
\text { кабря } \\
2020\end{array}$ \\
\hline Бета & В.1.351 & GH/501Y.V2 & 20H (V2) & $\begin{array}{l}\text { Южная Африка, } \\
\text { Май 2020 }\end{array}$ & $\begin{array}{l}18 \text { де- } \\
\text { кабря } \\
2020\end{array}$ \\
\hline Гамма & Р.1 & GR/501Y.V3 & 20J (V3) & $\begin{array}{l}\text { Бразилия, } \\
\text { ноябрь }\end{array}$ & $\begin{array}{l}11 \text { янва- } \\
\text { ря 2021 }\end{array}$ \\
\hline Дельта & В.1.617.2 & G/478K.V1 & 21А & $\begin{array}{l}\text { Индия, } \\
\text { Октябрь 2020 }\end{array}$ & $\begin{array}{l}\text { VОI: } \\
\text { апр.2021 } \\
\text { VOC: } 11 \\
\text { мая } \\
2021\end{array}$ \\
\hline
\end{tabular}




\begin{tabular}{|c|c|c|c|c|c|}
\hline \multicolumn{6}{|c|}{ Варианты, вызывающие интерес (VOIs) } \\
\hline Эпсилон & $\begin{array}{l}\text { B.1.427/ } \\
\text { B. } 1.429\end{array}$ & GH/452R.V1 & $21 \mathrm{C}$ & США, март 2020 & $\begin{array}{l}5 \text { марта } \\
2021\end{array}$ \\
\hline Дзета & P.2 & GR/484K.V2 & $20 \mathrm{~B}$ & $\begin{array}{l}\text { Бразилия, апр. } \\
2020\end{array}$ & $\begin{array}{l}17 \text { марта } \\
2021\end{array}$ \\
\hline Эта & B.1.525 & G/484K.V3 & 21D & $\begin{array}{l}\text { Многие страны, } \\
\text { декабрь } 2020\end{array}$ & $\begin{array}{l}17 \text { марта } \\
2021\end{array}$ \\
\hline Тета & P.3 & GR/1092K.V1 & $21 \mathrm{E}$ & $\begin{array}{l}\text { Филиппины, ян- } \\
\text { варь } 2021\end{array}$ & $\begin{array}{l}24 \text { марта } \\
2021\end{array}$ \\
\hline Йота & B.1.526 & GH/253G.V1 & $21 \mathrm{~F}$ & $\begin{array}{l}\text { США, ноябрь } \\
2020\end{array}$ & $\begin{array}{l}24 \text { марта } \\
2021\end{array}$ \\
\hline Каппа & B.1.617.1 & G/452R.V3 & $21 \mathrm{~B}$ & Индия, окт. 2020 & 4 апреля \\
\hline Лямбда & C. 37 & GR/452Q.V1 & 20D & $\begin{array}{l}\text { Перу, } \\
2020\end{array}$ & $\begin{array}{l}14 \text { июня } \\
2021\end{array}$ \\
\hline
\end{tabular}

\section{Фенотипические характеристики}

Имеющиеся данные о фенотипическом воздействии VOC и эффективности вакцины против VOC обобщены в Таблице 3.

Недавние исследования Дельта варианта в Соединенном Королевстве Великобритании и Северной Ирландии предполагают возможный повышенный риск тяжелого заболевания и подтверждают предыдущие наблюдения о повышенной трансмиссивности. Анализ, сравнивающий подтвержденные случаи дельта-варианта и альфа-варианта в Соединенном Королевстве с 29 марта до 20 мая 2021 г. показал, что вариант Дельта был связан с возможным повышенным риском госпитализации (отношение рисков 2,61, 95\% ДИ 1,56$4,36)$ и повышенным риском обращения за неотложной помощью или госпитализации (отношение рисков 1,67, 1,25-2,23) в пределах 14 дней от сбора образцов по сравнению с вариантом Alpha. Второй анализ, основанный на случаях, зарегистрированных в Соединенном Королевстве с 29 марта по 11 мая 2021 г. (данные о вариантах по состоянию на 25 мая 2021 г.), показал, что частота вторичных заражений была выше среди лиц, контактировавших с заболевшими Delta, по сравнению с лицами, контактировавшими с больными Alpha (2,6\% против 1,6\% среди лиц, которые путешествовали; 8,2\% против $12,4 \%$ среди контактов пациентов, которые не путешествовали). Необходим дальнейший анализ, чтобы лучше понять и подтвердить эти выводы. 
Таблица 4. Краткое описание фенотипических проявлений у вызывающих озабоченность вариантов (VOC)

\begin{tabular}{|c|c|c|c|c|}
\hline \multicolumn{5}{|c|}{ Обозначение ВО3 } \\
\hline & Альфа & Бета & Гамма & Дельта \\
\hline $\begin{array}{l}\text { Трансмис- } \\
\text { сивность }\end{array}$ & $\begin{array}{l}\text { Повышенная } \\
\text { трансмиссив- } \\
\text { ность и ско- } \\
\text { рость вторич- } \\
\text { ных зараже- } \\
\text { ний }\end{array}$ & $\begin{array}{l}\text { Повышенная } \\
\text { трансмис- } \\
\text { сивность }\end{array}$ & $\begin{array}{l}\text { Повышенная } \\
\text { трансмиссив- } \\
\text { ность }\end{array}$ & $\begin{array}{l}\text { Повышенная } \\
\text { трансмиссив- } \\
\text { ность и ско- } \\
\text { рость вторич- } \\
\text { ных зараже- } \\
\text { ний }\end{array}$ \\
\hline $\begin{array}{l}\text { Тяжесть за- } \\
\text { болевания }\end{array}$ & $\begin{array}{l}\text { Не подтвер- } \\
\text { ждено, воз- } \\
\text { можен повы- } \\
\text { шенный риск } \\
\text { госпитализа- } \\
\text { ции, тяжелого } \\
\text { течения забо- } \\
\text { левания и ле- } \\
\text { тальности } \\
\end{array}$ & $\begin{array}{l}\text { Не подтвер- } \\
\text { ждено, воз- } \\
\text { можен по- } \\
\text { вышенный } \\
\text { риск госпи- } \\
\text { тальной } \\
\text { смертности }\end{array}$ & $\begin{array}{l}\text { Не подтвер- } \\
\text { ждено, воз- } \\
\text { можен повы- } \\
\text { шенный риск } \\
\text { госпитализа- } \\
\text { ции }\end{array}$ & $\begin{array}{l}\text { Не подтвер- } \\
\text { ждено, воз- } \\
\text { можен повы- } \\
\text { шенный риск } \\
\text { госпитализа- } \\
\text { ции }\end{array}$ \\
\hline $\begin{array}{l}\text { Риск реин- } \\
\text { фекции }\end{array}$ & $\begin{array}{l}\text { Сохраняется } \\
\text { нейтрализу- } \\
\text { ющая актив- } \\
\text { ность, риск } \\
\text { повторного } \\
\text { заражения } \\
\text { остается ана- } \\
\text { логичным }\end{array}$ & $\begin{array}{l}\text { Сообщается } \\
\text { о снижении } \\
\text { нейтрализу- } \\
\text { ющей актив- } \\
\text { ности } \\
\text { Т-клеточный } \\
\text { ответ, вы- } \\
\text { званный ви- } \\
\text { русом } \\
\text { D614G, со- } \\
\text { храняет эф- } \\
\text { фективность }\end{array}$ & $\begin{array}{l}\text { Сообщается о } \\
\text { незначитель- } \\
\text { ном сниже- } \\
\text { нии нейтра- } \\
\text { лизующей ак- } \\
\text { тивности }\end{array}$ & $\begin{array}{l}\text { Сообщается о } \\
\text { снижении } \\
\text { нейтрализу- } \\
\text { ющей актив- } \\
\text { ности }\end{array}$ \\
\hline $\begin{array}{l}\text { Влияние на } \\
\text { диагностику }\end{array}$ & $\begin{array}{l}\text { Ограниченное } \\
\text { воздействие - } \\
\text { несостоятель- } \\
\text { ность мишени } \\
\text { гена } \\
(\mathrm{SGTF}) ; \\
\text { влияет на об- } \\
\text { щий резуль- } \\
\text { тат ОТ-ПЦР с } \\
\text { множествен- } \\
\text { ными мише- } \\
\text { нями, н не } \\
\text { наблюдается }\end{array}$ & $\begin{array}{l}\text { Не выявлено } \\
\text { влияние на } \\
\text { ОТ-ПЦР и } \\
\text { ДЭТ на анти- } \\
\text { ген }\end{array}$ & Данных нет & Данных нет \\
\hline
\end{tabular}




\begin{tabular}{|c|c|c|c|c|}
\hline & $\begin{array}{l}\text { влияния на } \\
\text { ДЭТ на анти- } \\
\text { ген }\end{array}$ & & & \\
\hline $\begin{array}{l}\text { Влияние на } \\
\text { эффектив- } \\
\text { ность вакцин }\end{array}$ & 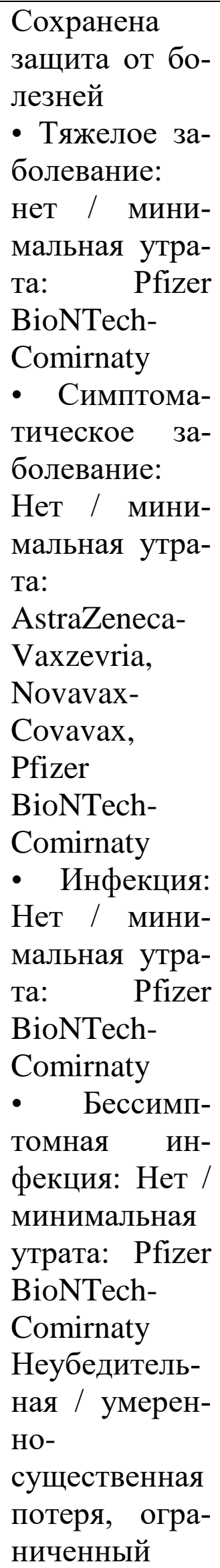 & 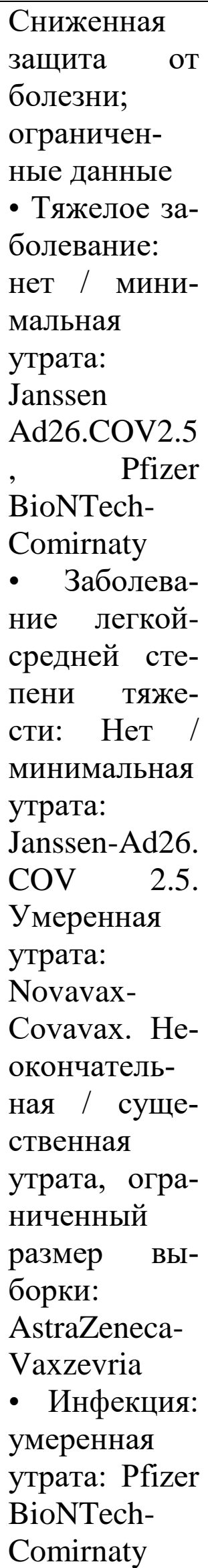 & $\begin{array}{l}\text { Вероятна за- } \\
\text { щита от бо- } \\
\text { лезни; очень } \\
\text { ограниченные } \\
\text { данные толь- } \\
\text { ко по одной } \\
\text { вакцине } \\
\text { Симптомати- } \\
\text { ческое забо- } \\
\text { левание: Нет / } \\
\text { минимальная } \\
\text { утрата: } \\
\text { Sinovac- } \\
\text { СоronaVac } \\
\text { - Инфекция: } \\
\text { Нет / мини- } \\
\text { мальная утра- } \\
\text { та: Sinovac- } \\
\text { CoronaVac }\end{array}$ & $\begin{array}{l}\text { Вероятна за- } \\
\text { щита от бо- } \\
\text { лезни; очень } \\
\text { ограниченные } \\
\text { данные толь- } \\
\text { ко по двум } \\
\text { вакцинам } \\
\text { - Тяжелая бо- } \\
\text { лезнь: Нет } \\
\text { минимальная } \\
\text { утрата: Pfizer } \\
\text { BioNTech- } \\
\text { Comirnaty, } \\
\text { АstraZeneca- } \\
\text { Vaxzevria. } \\
\text { - Cимптома- } \\
\text { тическое за- } \\
\text { болевание: } \\
\text { Нет / мини- } \\
\text { мальная утра- } \\
\text { та: Pfizer } \\
\text { BioNTech- } \\
\text { Comirnaty, } \\
\text { AstraZeneca- } \\
\text { Vaxzevria. } \\
\text { Mинимальная } \\
\text { / умеренная } \\
\text { утрата: Pfizer } \\
\text { BioNTech- } \\
\text { Comirnaty, } \\
\text { AstraZeneca- } \\
\text { Vaxzevria }\end{array}$ \\
\hline
\end{tabular}




\begin{tabular}{|c|c|c|c|c|}
\hline & $\begin{array}{l}\text { размер вы- } \\
\text { борки: } \\
\text { AstraZeneca- } \\
\text { Vaxzevria }\end{array}$ & \begin{tabular}{ll} 
- & \multicolumn{2}{c}{ Бессимп- } \\
томная & ин- \\
фекция: & нет \\
данных. &
\end{tabular} & & \\
\hline $\begin{array}{l}\text { Влияние на } \\
\text { нейтрализа- } \\
\text { цию вакци- } \\
\text { ной (полная } \\
\text { вакцинация) }\end{array}$ & $\begin{array}{l}\text { • Отсутствие / } \\
\text { минимальная } \\
\text { утрата: } \\
\text { Bharat- } \\
\text { Covaxin, } \\
\text { Gamaleya- } \\
\text { Sputnik V, } \\
\text { Moderna- } \\
\text { mRNA-1273, } \\
\text { Novavax- } \\
\text { Covavax, Pfiz- } \\
\text { er BioNTech- } \\
\text { Comirnaty, } \\
\text { Beijing } \\
\text { CNBG- } \\
\text { BBIBP-CorV, } \\
\text { Sinovac- } \\
\text { CoronaVac } \\
\text { - Mинималь- } \\
\text { ная / средняя } \\
\text { утрата: } \\
\text { AstraZeneca- } \\
\text { Vaxzevria }\end{array}$ & $\begin{array}{l}\text { - Минималь- } \\
\text { ная / умерен- } \\
\text { ная утрата: } \\
\text { Bharat- } \\
\text { Covaxin, Пе- } \\
\text { кин CNBG- } \\
\text { BBIBP-CorV, } \\
\text { Sinovac- } \\
\text { CoronaVac, } \\
\text { Anhui ZL - } \\
\text { pекомби- } \\
\text { нантная } \\
\text { • Потеря от } \\
\text { минимальной } \\
\text { до значи- } \\
\text { тельной: } \\
\text { Моderna- } \\
\text { mRNA-1273, } \\
\text { Pfizer } \\
\text { BioNTеch- } \\
\text { Comirnaty } \\
\text { • Утрата от } \\
\text { умеренной } \\
\text { до значи- } \\
\text { тельной: } \\
\text { AstraZеnеса- } \\
\text { Vaxzevria, } \\
\text { Gamaleya- } \\
\text { Sputnik V, } \\
\text { Janssen- } \\
\text { Ad26.COV } \\
\text { 2.5, Novavax- } \\
\text { Covavax }\end{array}$ & $\begin{array}{l}\text { - Отсутствие / } \\
\text { минимальная } \\
\text { утрата: } \\
\text { AstraZeneca- } \\
\text { Vaxzevria, } \\
\text { Sinovac- } \\
\text { CoronaVac } \\
\text { - Минималь- } \\
\text { ная / умерен- } \\
\text { ная утрата: } \\
\text { Moderna- } \\
\text { мPHК-1273, } \\
\text { Pfizer } \\
\text { BioNTech- } \\
\text { Comirnaty }\end{array}$ & $\begin{array}{l}\text { - Отсутствие / } \\
\text { минимальная } \\
\text { утрата: } \\
\text { Bharat- } \\
\text { Covaxin } \\
\text { Отсутствие / } \\
\text { минимальная } \\
\text { или незначи- } \\
\text { тельная утра- } \\
\text { та Pfizer } \\
\text { BioNTech- } \\
\text { Comirnaty, } \\
\text { Bharat- } \\
\text { Covaxin } \\
\text { • Cуществен- } \\
\text { ная утрата: } \\
\text { однократная } \\
\text { доза } \\
\text { AstraZeneca- } \\
\text { Vaxzevria }\end{array}$ \\
\hline
\end{tabular}




\section{Географическое распространение}

По мере усиления деятельности по надзору для выявления вариантов SARS-CoV-2 на местном и национальном уровнях, в том числе путем стратегического геномного секвенирования, обмена последовательностями и вспомогательными метаданными, количество стран / территорий / регионов (далее стран), сообщающих о VOC, продолжает увеличиваться (Рисунок 4). В последние две недели об Альфа продолжали сообщать в новых странах, включая небольшие островные государства в регионах Америки и ЮгоВосточной Азии. Дельта, о котором сейчас сообщают в 85 странах мира, продолжает регистрироваться в новых странах во всех регионах ВОЗ, 11 из которых были зарегистрированы за последние две недели. Это распределение следует интерпретировать с должным учетом ограничений эпиднадзора, включая различия в возможностях определения последовательности и стратегиях отбора проб между странами.

Рис. 4. Страны, территории и районы, сообщающие о вариантах Alpha, Beta, Gamma и Delta, по состоянию на 22 июня 2021 г.

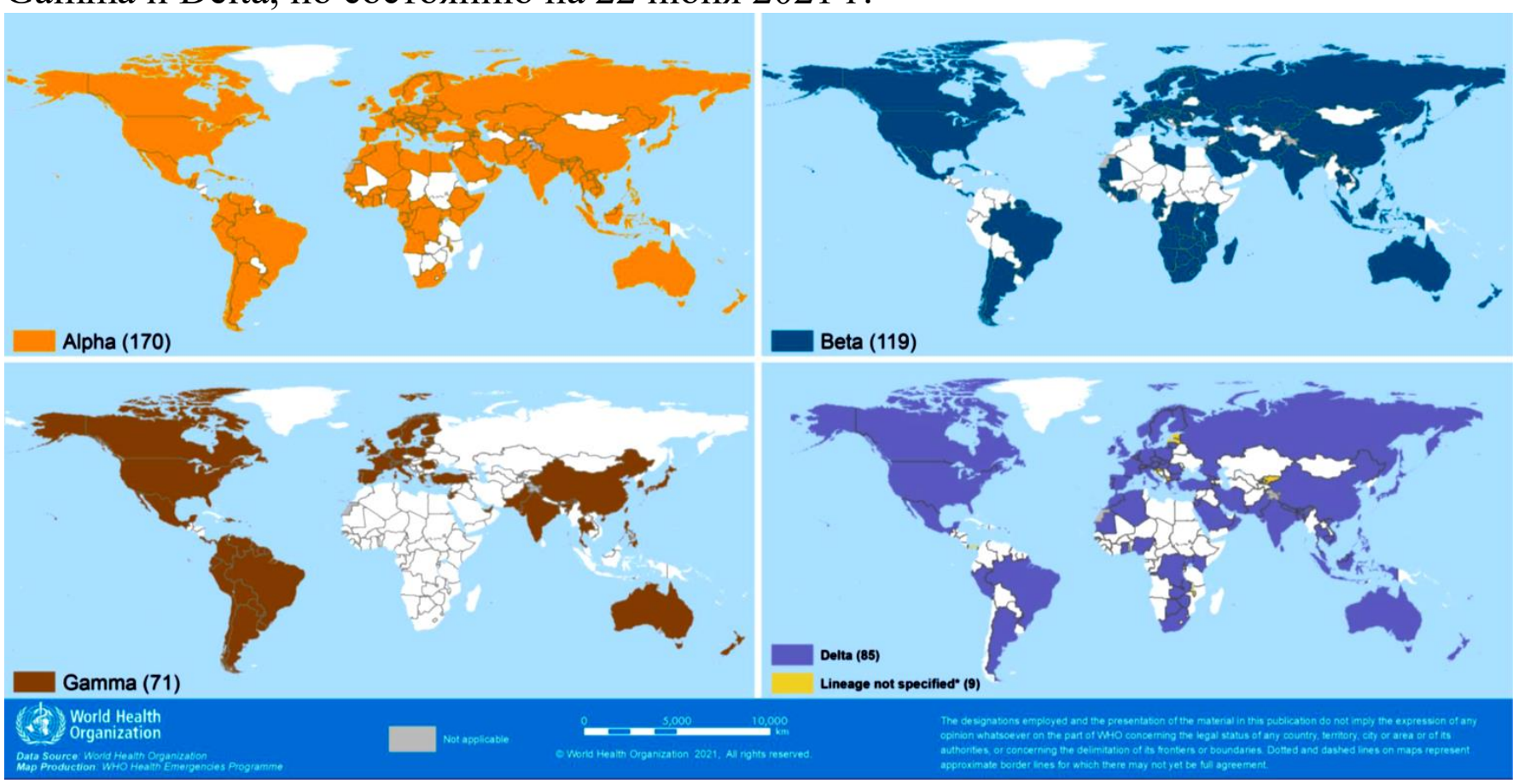




\section{Научные публикации}

Med Sci Monit. 2021 Jun 21;27:e933622.

doi: 10.12659/MSM.933622.

Editorial: Revised World Health Organization (WHO) Terminology for Variants of Concern and Variants of Interest of SARS-CoV-2

От редакции: Пересмотренная терминология Всемирной организации здравоохранения (ВОЗ) для вариантов, вызывающих озабоченность, и вариантов, представляющих интерес, SARS-CoV-2

Dinah Parums 1

Глобальная пандемия коронавирусной болезни 2019 года (COVID-19) выявила тысячи последовательностей генома коронавируса 2 тяжелого острого респираторного синдрома (SARS-CoV-2). 31 мая 2021 года Рабочая группа Всемирной организации здравоохранения (ВОЗ) по эволюции вирусов объявила о своих рекомендациях по пересмотру наименования вызывающих беспокойство вариантов SARS-CoV-2 (VOC) и представляющих интерес вариантов (VOI). Эта новая система номенклатуры может улучшить мониторинг инфекций, инфекционный контроль и обмен данными исследований вирусной геномики и эпидемиологии. Цель данной редакционной статьи представить обновленную информацию о текущей пересмотренной терминологии ВОЗ для VOC и VOI SARS-CoV-2.

J Infect Dis. 2021 Jun 22;jiab328.

doi: 10.1093/infdis/jiab328. Online ahead of print.

Accelerating the evolution of SARS-CoV-2 - a risk of combining dexamethasone and tocilizumab for severe COVID-19

Ускорение развития SARS-CoV-2 - риск сочетания дексаметазона и тоцилизумаба при тяжелой форме COVID-19

David Koeckerling $\stackrel{1}{ }$, Joseph Barker ${ }^{2}$

Новые данные открытых рандомизированных исследований без контроля плацебо предполагают потенциальные преимущества в отношении смертности от комбинации кортикостероидов с антагонистом рецепторов IL6 тоцилизумабом при тяжелой форме COVID-19. И наоборот, двойная иммуномодуляция может ослабить противовирусные реакции и замедлить выведение вируса, позволяя SARS-CoV-2 расширять свою популяцию и накапливать генетическое разнообразие у отдельных хозяев. Создание пула хозяев с 
генетически разнообразными вирусными популяциями при введении нового селективного давления в форме иммунитета, вызванного вакцинацией, может ускорить процесс антигенного дрейфа в SARS-CoV-2. Однако клинические испытания на сегодняшний день в значительной степени не учитывают вирусные исходы, а данные о вирусной кинетике в ответ на иммуномодуляцию скудны. Совместное введение противовирусных агентов с иммуномодуляцией может служить потенциальной стратегией, способствующей очищению от вирусов и снижению риска генетической диверсификации.

Infect Genet Evol. 2021 Jun 18;104973.

doi: 10.1016/j.meegid.2021.104973. Online ahead of print.

Global variation in SARS-CoV-2 proteome and its implication in prelockdown emergence and dissemination of 5 dominant SARS-CoV-2 clades

\section{Глобальная изменчивость протеома SARS-CoV-2 и ее значение в появ- лении и распространении 5 доминирующих клад SARS-CoV-2}

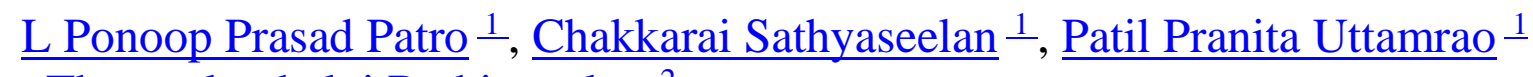
, Thenmalarchelvi Rathinavelan 2

SARS-CoV-2 в настоящее время вызывает серьезные проблеммы во всем мире благодаря своей эффективной передаче и распространению. Чтобы отследить стойкость мутаций, а также появление новых мутаций на ранней стадии пандемии, был проведен сравнительный анализ целого протеома SARS-CoV-2 путем рассмотрения вручную отобранных 31389 полных последовательностей генома из 84 стран. Среди 7 высоко повторяющихся (процентная частота > 10\%) мутаций (Nsp2: T85I, Nsp6: L37F, Nsp12: P323L, Spike: D614G, ORF3a: Q57H, N белок: R203K и N белок: G204R), N-белок: R203K и Nprotein: G204R являются сопутствующими (зависимыми) мутациями, и Nsp12: P323L и Spike: D614G часто появляются одновременно. Часто повторяющиеся мутации Spike: D614G, Nsp12: P323L и Nsp6: L37F, а также умеренно повторяющиеся (процентная частота от 1 до 10\%) мутации ORF3a: G251V, ORF8: L84S позволили выделить 5 основных клад. Кроме того, появление в ORF3a: Q57H и Nsp2: T85I, ORF3a: Q57H и N белке: R203K и G204R вместе с Nsp12: P323L и Spike: D614G привело к 3 дополнительным подкладам. Точно так же белок Nsp6: L37F и ORF3a: G251V вместе привели к появлению новой подклады. Тем не менее, ORF8 не встречается вместе с ORF3a: G251V или Nsp6: L37F. Интересно, что Nsp6: L37F и ORF8: L84S встречаются независимо от мутаций Nsp12: P323L и Spike: D614G. Эти клады развились на ранней стадии пандемии и распространились по 84 странам. Кроме 
того, обнаружено, что Nsp10 обладает высокой устойчивостью к мутациям, поэтому его можно использовать для разработки лекарств/вакцин, а соответствующую последовательность гена можно использовать для диагностики. Вкратце, исследование сообщает о разнообразии антигенов SARS-CoV-2 по всему миру на ранней стадии пандемии и помогает понять эволюцию вируса.

Chembiochem. 2021 Jun 23.

doi: 10.1002/cbic.202100191. Online ahead of print.

Preliminary Structural Data Revealed that the SARS-CoV-2 B.1.617 Variant's RBD binds to ACE2 receptor stronger than the Wild Type to Enhance the Infectivity

\section{Предварительные структурные данные показали, что RBD варианта SARS-CoV-2 B.1.617 связывается с рецептором ACE2 сильнее, чем дико- го типа, для повышения инфекционности}

$\underline{\text { Abbas Khan }}^{1}$, Dong-Qing Wei $\stackrel{2}{2}$, и др.

Развитие новых вариантов SARS-CoV-2 по всему миру сделало пандемию COVID-19 более тревожной, что еще больше повлияло на систему здравоохранения и иммунитет. Новые вариации, которые являются уникальными для рецептор-связывающего мотива (RBM) гликопротеина шипа рецепторсвязывающего домена (RBD), то есть L452R-E484Q, могут играть иную роль y B.1.617, также известном как G / 452R.V3 , в патогенности и лучшей выживаемости варианта по сравнению с диким типом. Следовательно, необходим тщательный анализ, чтобы понять влияние этих мутаций на связывание с рецептором хозяина (RBD) и направить разработку новых терапевтических средств. В этом исследовании мы использовали методы структурного и биомолекулярного моделирования, чтобы изучить влияние специфических мутаций (L452R-E484Q) в варианте B.1.617 на связывание RBD с рецептором ACE2 хозяина. Наш анализ показал, что В.1.617 обладают другим поведением за счет изменения динамической устойчивости, остаточной гибкости и структурной компактности. Кроме того, новый вариант также существенно изменил свойства соединительной сети и структурно-динамические свойства. Использовали метод MM / GBSA, который дополнительно установил различия в связывании между диким типом и вариантом В.1.617. Это исследование дает мощный импульс для разработки новых лекарств против новых вариантов SARS-CoV-2. 
Cell. 2021 Jun 9;S0092-8674(21)00709-1.

doi: 10.1016/j.cell.2021.06.008. Online ahead of print.

Identification of novel bat coronaviruses sheds light on the evolutionary origins of SARS-CoV-2 and related viruses

\section{Идентификация новых коронавирусов летучих мышей проливает свет на эволюционное происхождение SARS-CoV-2 и родственных вирусов}

$\underline{\text { Hong Zhou }} \stackrel{1}{-}$, Jingkai Ji $\stackrel{1}{-}$, и др.

Несмотря на открытие коронавирусов животных, связанных с SARS$\mathrm{CoV}-2$, эволюционное происхождение этого вируса не установлено. Мы описываем мета-транскриптомное исследование 411 образцов летучих мышей, собранных из небольшого географического региона в провинции Юньнань, Китай, в период с мая 2019 года по ноябрь 2020 года. Мы идентифицировали 24 полноразмерных генома коронавируса, в том числе четыре новых, связанных с SARS-CoV-2, и три вируса, связанных с SARS-CoV. Вирус Rhinolophus pusillus RpYN06 был ближайшим родственником SARS-CoV-2 в большей части генома, хотя он обладал более дивергентным $\mathrm{S}$ геном. Три других коронавируса, связанных с SARS-CoV-2, несут генетически отличный S ген, который может слабо связываться с рецептором hACE2 in vitro. Экологическое моделирование предсказало сосуществование до 23 видов летучих мышей Rhinolophus, при этом самые большие смежные горячие точки простираются от Южного Лаоса и Вьетнама до Южного Китая. Наше исследование подчеркивает значительное разнообразие коронавирусов летучих мышей в местном масштабе, включая близких родственников SARS-CoV-2 и SARS-CoV. 